EFFECTS OF LOW-LEVEL RADIOACTIVE-WASTE DISPOSAL

ON WATER CHEMISTRY IN THE UNSATURATED ZONE AT A

SITE NEAR SHEFFIELD, ILLINOIS, 1982-84

By C.A. Peters, R.G. Striegl, P.C. Mills, and R.W. Healy

U.S. GEOLOGICAI SURVEY

Open-File Report 90-373 
U.S. DEPARTMENT OF THE INTERIOR

MANUEL LUJAN, JR., Secretary

U.S. GEOLOGICAL SURVEY

Dallas L. Peck, Director

For additional information write to:

District Chief U.S. Geological Survey 102 E. Main St., 4th Floor Urbana, IL 61801
Copies of the report can be purchased from:

U.S. Geological Survey Books and Open-File Reports Section Federal Center, Box 25425 Denver, CO 80225 
Abstract. .........................................

Introduction. ........................................

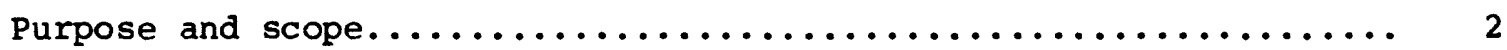

site history ......................................

Related studies...................................

Acknowledgments. ..................................

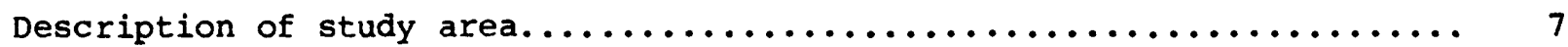

climate...................................... 7

Geology ...........................................

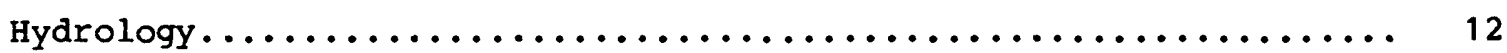

Methods of investigation..................................

Collection and analysis of geologic materials................ 15

Collection and analysis of water samples....................17

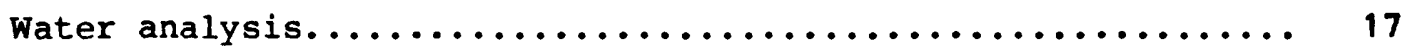

Collection of precipitation samples.................... 18

Collection of water samples from the unsaturated zone....... 18

Collection of water samples from the saturated zone......... 27

Interpretive techniques.............................. 27

Properties of geologic materials............................. 28

Chemistry of water samples................................ 33

Precipitation. ................................... 34

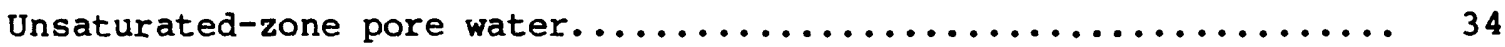

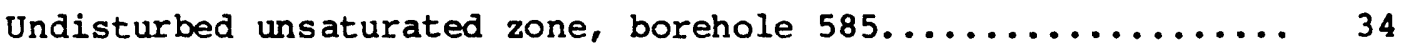

Disturbed unsaturated zone, above trench................ 37

Disturbed unsaturated zone, below trench................ 42

Saturated-zone water.................................448

Effects of radioactive-waste disposal on water chemistry in the unsaturated zone.................................... 50

Affected constituents.............................. 50

Carbonate minerals............................... 50

sulfate..................................... 54

other inorganic constituents..................... 58

Dissolved organic carbon........................... 61

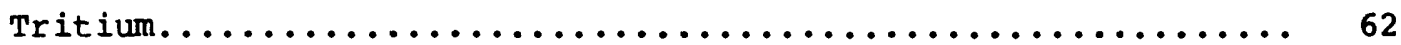

Contributing influences..............................64

Summary ............................................ 67

Selected references....................................69 
1-3. Maps showing:

1. Location of Sheffield disposal site.............. 3

2. Topography at the Sheffield site................ 4

3. Location of trenches, tunnel, and borings used to determine physical and chemical properties of geologic materials and soil gas at the Sheffield

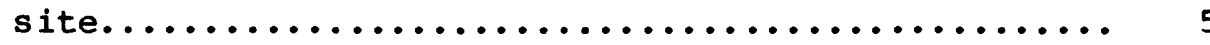

4-5. Diagrams showing:

4. Side and end views of a typical trench............. 6

5. Time-stratigraphic and rock-stratigraphic classification of the Illinois State Geological Survey...... 8

6. Map showing location of lines of section, lysimeters, wells, and precipitation collector................. 9

7. Geologic section $A-A{ }^{\circ}$ of the Sheffield site............ 10

8. Geologic section $B-B^{\prime}$ of the sheffield site............. 11

9. Map showing surface- and ground-water drainage, including

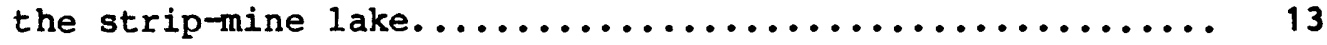

10. Geologic section $A-A$ ' showing probable flow paths in

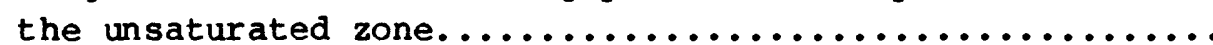

11. Schematic diagram showing typical installation of pore-water pressure-vacuum lysimeter.................. 19

12. Geologic section showing lysimeter locations off-site

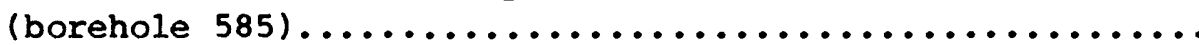

13. Geologic section $C-C$ ' showing on-site, above-trench

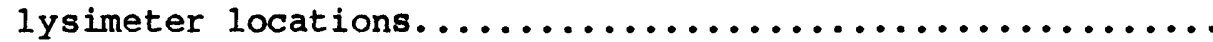

14. Geologic section $A-A$ ' showing lysimeter locations in

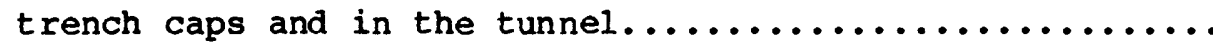

15-16. Piper diagrams showing:

15. Ionic composition of water collected from off-site lysimeters (borehole 585) and precipitation..........

16. Ionic composition of pore water collected from

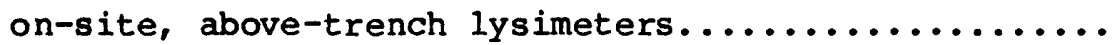

17. Graph showing seasonal trends in evapotranspiration and soil saturation (A), and tritium concentrations at two above-trench lysimeter locations (B), July 1982 through

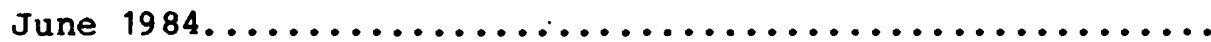

18. Piper diagram showing ionic composition of pore water collected from on-site, below-trench lysimeters in the Hulick Till Member of the Glasford Formation.........

19-20. Graphs showing:

19. Seasonal trends in tritium concentrations in pore water from three below-trench lysimeters,

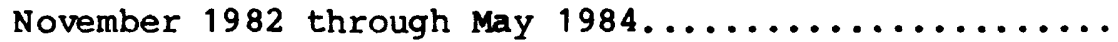




\section{ILLUSTRATIONS}

\section{Figures}

19-20. Graphs showing:--Continued

20. Tritium concentrations in pore water from three below-trench lysimeters, November 1982 through

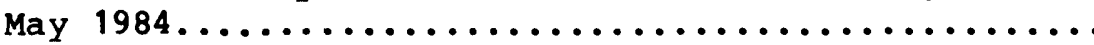

21. Piper diagram showing ionic composition of water collected

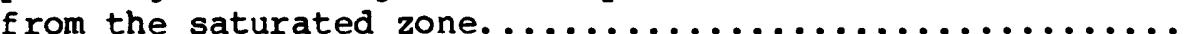

22-28. Graphs showing:

22. Relation of dolomite saturation index to calcite

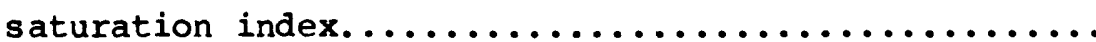

23. Average concentrations of calcium, magnesium, and sodium in pore water from lithologic units on-site (above-trench and below-trench lysimeters) and off-site (borehole 585 lysimeters), July 1982 through May 1984 .

24. Average concentration of sodium in pore water relative to average percent montmorillonite in the clay-mineral fraction of four lithologic units off-site (borehole 585 lysimeters), October 1982 through May 1984.

25. Calcium content of geologic materials and molar ratios of calcium to magnesium in pore water relative to depth and geologic material off-site (borehole 585 lysimeters).

26. Average concentration of sulfate in pore water from lithologic units on-site (above-trench and belowtrench lysimeters) and off-site (borehole 585 lysimeters), July 1982 through May 1984...........

27. Average concentration of silica in pore water from above-trench and below-trench lysimeters, August 1982 through May $1984 \ldots \ldots \ldots \ldots \ldots \ldots \ldots \ldots \ldots \ldots \ldots$

28. Average concentration of tritium in pore water and ground water, July 1982 through May 1984..........

29. Diagram showing generalized flow paths of water in the unsaturated and saturated zones, and reactions occurring in each lithologic unit.........................

30. Box and whisker plots showing statistical summary of selected chemical properties in pore water in lithologic units on-site (above-trench and below-trench lysimeters) and off-site (borehole 585 lysimeters), June 1982 through June $1984 \ldots \ldots \ldots \ldots \ldots \ldots \ldots \ldots \ldots \ldots \ldots \ldots \ldots \ldots \ldots \ldots$ 
Table 1. Laboratory procedures for analyses of physical and chemical properties of geologic materials....................

2. Concentrations of selected constituents for a known water sample, for the known sample collected through a leached porous-ceramic cup, and the percent difference between the concentrations.

3. Mean concentrations of selected metals in water samples collected using lysimeters that contain, and that do not contain, galvanized materials...................

4. Values of specific conductance, $\mathrm{pH}$, alkalinity (as $\mathrm{CaCO}_{3}$ ), and chloride for untreated and for silica-saturated solutions from well 505, distilled water, and distilled water acidified to $\mathrm{pH} 2.7$ with sulfuric acid............

5. Concentrations of selected constituents in pore water collected at -20 and -80 kilopascals suction............

6. Concentrations of selected constituents for uncomposited and composited pore-water samples...................

7. Mean values of physical properties for geologic materials....

8. Mean values of chemical properties for geologic materials....

9. Mean values of mineralogic properties for geologic materials.

10. Mean, standard deviation, and number of pore-water samples analyzed for selected constituents at off-site (borehole

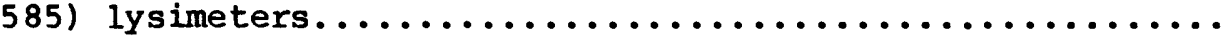

11. Mean, standard deviation, and number of pore-water samples for selected constituents at on-site lysimeters..........

12. Equilibrium constants used in calculation of saturation indices.....................................

13. Saturation indices for calcite and dolomite on-site and off-site.................................

14. Physical characteristics of water-chemistry sampling sites...

15. Chemical analyses of precipitation....................

16. Chemical analyses of pore water in the unsaturated zone

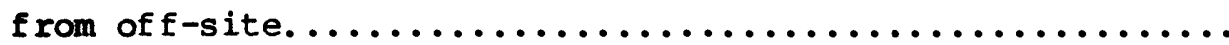

17. Chemical analyses of pore water in the unsaturated zone

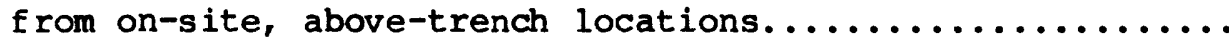

18. Chemical analyses of pore water in the unsaturated zone from on-site, below-trench locations.................. 96

19. Tritium concentrations in pore water from soil cores........110

20. Chemical constituents in saturated-zone water.............113 
Metric (International System) units used in this report may be converted to inch-pound units by use of the following conversion factors:

\begin{tabular}{|c|c|c|}
\hline Multiply Metric Unit & $\underline{\text { By }}$ & To Obtain Inch-Pound Unit \\
\hline micrometer $(\mu \mathrm{m})$ & 0.00003937 & inch (in.) \\
\hline millimeter (mm) & 0.03937 & inch (in.) \\
\hline meter (m) & 3.281 & foot (ft) \\
\hline kilometer $(\mathrm{km})$ & 0.6214 & mile (mi) \\
\hline cubic meter $\left(\mathrm{m}^{3}\right)$ & 35.31 & cubic foot $\left(\mathrm{ft}^{3}\right)$ \\
\hline hectare (ha) & 2.471 & acre \\
\hline kilogram (kg) & 2.205 & pound, avoirdupois (lb) \\
\hline gram (g) & 0.03527 & ounce, avoirdupois (oz) \\
\hline liter (L) & 0.2642 & gallon (gal) \\
\hline liter $(L)$ & 33.82 & ounce, fluid (oz) \\
\hline milliliter (mL) & 0.03382 & ounce, fluid (oz) \\
\hline $\begin{array}{l}\text { gram per cubic centimeter } \\
\left(\mathrm{g} / \mathrm{cm}^{3}\right)\end{array}$ & 0.5782 & $\begin{array}{l}\text { ounce per cubic inch } \\
\left(02 / \text { in }^{3}\right)\end{array}$ \\
\hline $\begin{array}{l}\text { square meter per gram } \\
\left(\mathrm{m}^{2} / \mathrm{g}\right)\end{array}$ & 304.2 & $\begin{array}{l}\text { square foot per ounce } \\
\left(f t^{2} / o z\right)\end{array}$ \\
\hline kilopascal (kPa) & $\begin{array}{l}0.1450 \\
0.009869\end{array}$ & $\begin{array}{l}\text { pound per square inch }\left(1 \mathrm{~b} / \mathrm{in}^{2}\right) \\
\text { atmosphere }(\mathrm{atm})\end{array}$ \\
\hline
\end{tabular}

degree Celsius $\left({ }^{\circ} \mathrm{C}\right) \quad{ }^{\circ} \mathrm{F}=1.8 \times{ }^{\circ} \mathrm{C}+32$ degree Fahrenheit $\left({ }^{\circ} \mathrm{F}\right)$ 


\section{Multiply Metxic Unit}

$$
\text { nanocurie ( } \mathrm{nCi} \text { ) }
$$

nanocurie per liter (nCi/L)

nanocurie per liter (nCi/L)

picocurie per gram (pCi/g)

milligrams per liter (mg/L)

micrograms per liter $(\mu \mathrm{g} / \mathrm{L})$

milligrams per liter calcium carbonate (mg/L $\mathrm{CaCO}_{3}$ )
By

0.02702

37.01

310.6

0.03701

1.00

1.00

1.219
To Obtain Inch-Pound Unit

becquerel (Bq)

becquerel per liter (Bq/L)

tritium unit (TU)

becquerel per gram $(\mathrm{Bq} / \mathrm{g})$

parts per million (ppm)

parts per billion (ppb)

milligrams per liter bicarbonate $\left(\mathrm{mg} / \mathrm{L} \mathrm{HCO}_{3}\right)$

Milligrams per liter (mg/L) X F1 - milliequivalents per liter (meq/L); milligrams per liter (mg/L) x F2 - millimoles per liter (mols/L)

$\begin{array}{lcc} & \mathrm{F} 1 & \mathrm{~F} 2 \\ \text { Bicarbonate }\left(\mathrm{HCO}_{3}^{-}\right) & 0.01639 & 0.01639 \\ \text { Calcium }\left(\mathrm{Ca}^{++}\right) & .04990 & .02495 \\ \text { Chloride }\left(\mathrm{Cl}^{-}\right) & .02821 & .02821 \\ \text { Iron }(\mathrm{Fe}) & --- & .01791 \\ \text { Magnesium }\left(\mathrm{Mg}^{++}\right) & .08229 & .04114 \\ \text { Silica }\left(\mathrm{SiO}_{2}\right) & --- & .01664 \\ \text { Sodium }\left(\mathrm{Na}^{+}\right) & .04350 & .04350 \\ \text { Strontium }\left(\mathrm{Sr}^{++}\right) & .02283 & .01141 \\ \text { Sulfate }\left(\mathrm{SO}_{4}^{--}\right) & .02082 & .01041 \\ \text { zinc }\left(\mathrm{zn}^{++}\right) & .03059 & .01530\end{array}$

Sea level: In this report, "sea level" refers to the National Geodetic Vertical Datum of 1929 (NGVD of 1929)--a geodetic datum derived from a general adjustment of the first-order level nets of both the United States and Canada, formerly called Sea Level Datum of 1929. 
EFFECTS OF LOW-LEVEL RADIOACTIVE-WASTE DISPOSAL ON WATER CHEMISTRY IN

THE UNSATURATED ZONE AT A SITE NEAR SHEFFIELD, ILLINOIS, 1982-84

By C.A. Peters, R.G. Striegl, P.C. Mills, and R.W. Healy

\author{
ABSTRACT
}

A 1982-84 field study defined the chemistry of water collected from the unsaturated zone at a low-level radioactive-waste disposal site near Sheffield, Bureau County, Illinois. Chemical data were evaluated to determine the principal naturally occurring geochemical reactions in the unsaturated zone and to evaluate waste-induced ef fects on pore-water chemistry.

Samples of precipitation, unsaturated-zone pore water, and saturated-zone water were analyzed for specific conductance, pH, alkalinity, major cations and anions, dissolved organic carbon, gross alpha and beta radiation, and tritium. Little change in concentration of most major constituents in the unsaturated-zone water was observed with respect to depth or distance from disposal trenches. Tritium and dissolved organic carbon concentrations were, however, dependent on proximity to trenches. The primary reactions, both onsite and off-site, were carbonate and clay dissolution, cation exchange, and the oxidation of pyrite.

The major difference between on-site and off-site inorganic water chemistry resulted from the removal of the Roxana Silt and the Radnor Till Member of the Glasford Formation from on-site. Off-site, the Roxana silt contributed substantial quantities of sodium to solution from montmorillonite dissolution and associated cation-exchange reactions. The Radnor Till Member provided exchange surfaces for magnesium.

Precipitation at the site had an ionic composition of calcium $z$ inc sulfate and an average pH of 4.6. Within 0.3 meter of the land surface, infiltrating rain water or snowmelt changed to an ionic composition of calcium sulfate offsite and calcium bicarbonate on-site and had an average pH of 7.9 ; below that depth, pH averaged 7.5 and the ionic composition generally was calcium magnesium bicarbonate. Alkalinity and specific conductance differed primarily according to composition of geologic materials. Tritium concentrations ranged from 0.2 (detection limit) to 1,380 nanocuries per liter.

The methods of constructing, installing, and sampling with lysimeters were evaluated to ensure data reliability. These evaluations indicate that, with respect to most constituents, the samples retrieved from the lysimeters accurately represented pore-water chemistry. 


\section{INTRODUCTION}

Disposal of low-level radioactive waste in Pleistocene and Holocene deposits near Sheffield, Bureau County, Illinois (fig. 1), has caused rearrangement of existing geologic materials and placed chemically reactive and potentially hazardous substances in the unsaturated zone. In order to improve understanding of the hydrologic effects of the disposal operations, the U.S. Geological Survey began a series of field investigations at the disposal site in 1976. This study of the hydrogeochemistry of the unsaturated zone is one part of that research effort.

\section{Purpose and scope}

This report details the changes in the chemistry of pore water as it infiltrates through areas undisturbed and disturbed by waste-disposal operations. The report (1) describes the techniques used to obtain representative samples of geologic materials and water from the unsaturated zone; (2) describes the chemistry of geologic materials and water in the unsaturated and saturated zones at off-site and on-site locations; and (3) infers, by statistical analy$s$ is and use of geochemical models, the geochemical reactions that occur naturally in the unsaturated zone and the effects of low-level radioactivewaste disposal on pore-water chemistry.

\section{Site History}

The Sheffield low-level radioactive-waste disposal site is located on 8.1 hectares of rolling terrain $5 \mathrm{~km}$ (kilometers) southwest of sheffield, Illinois (figs. 1 and 2). The site was established by authority of the 1963 Illinois Radioactive Waste Act to dispose of wastes generated in Illinois by nuclear plants, hospitals, medical research facilities, and industry. Twentyone trenches (fig. 3) were excavated and filled with solidified low-level radioactive waste. The trenches were backfilled with earthen material, and, for some trenches, a layer of clayey silt was compacted over the backfill. The compacted layer inhibits the infiltration of precipitation into the trenches. Additional earthen material was mounded lengthwise over the trenches to form ridges that direct runoff from the trench caps (fig. 4).

Burial of waste at the disposal facility was terminated in 1978 because all licensed space had been used. During the period 1967-78, nearly $90,500 \mathrm{~m}^{3}$ (cubic meters) of waste were buried, including $13,000 \mathrm{~g}$ (grams) of plutonium$239,1.7 \mathrm{~g}$ of uranium-233, 40,000 g of uranium-235, and $270,000 \mathrm{~kg}$ (kilograms) of source material (R. Dragonette, U.S. Nuclear Regulatory Commission, written commun., 1979). The buried wastes include such items as resins, the carcasses of laboratory animals, sorbed liquids, glassware, building materials, clothing, containerized gases, paper, and cleanup materials (Foster and others, 1984). Containment vessels for these materials include steel drums, wooden crates, plastic containers, concrete casks, and cardboard cartons. A chemical-waste disposal facility is located northwest of the site and is separated by a $60-\mathrm{m}$ (meter)-wide buffer zone. 


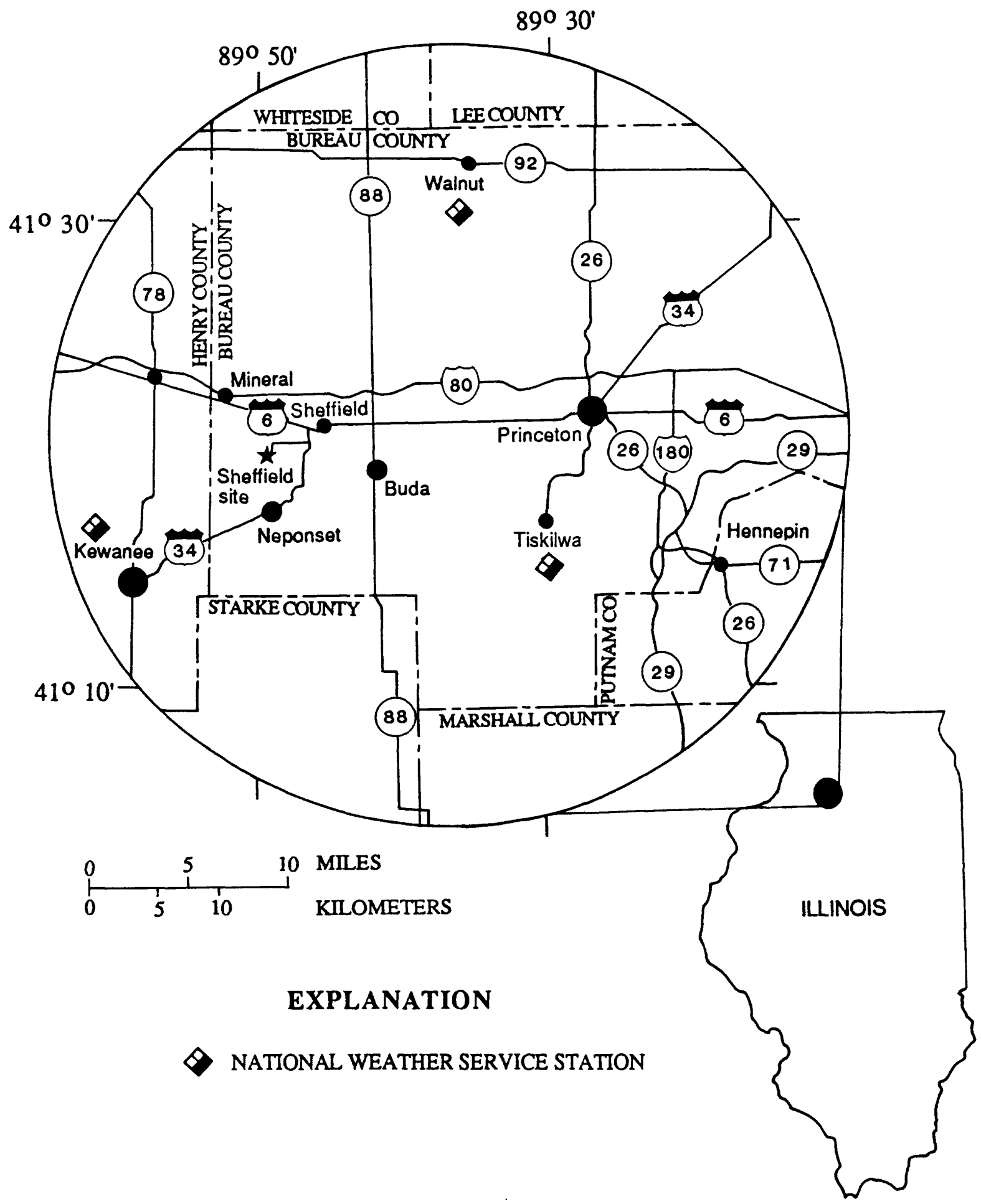

Figure 1.--Location of Sheffield disposal site. 


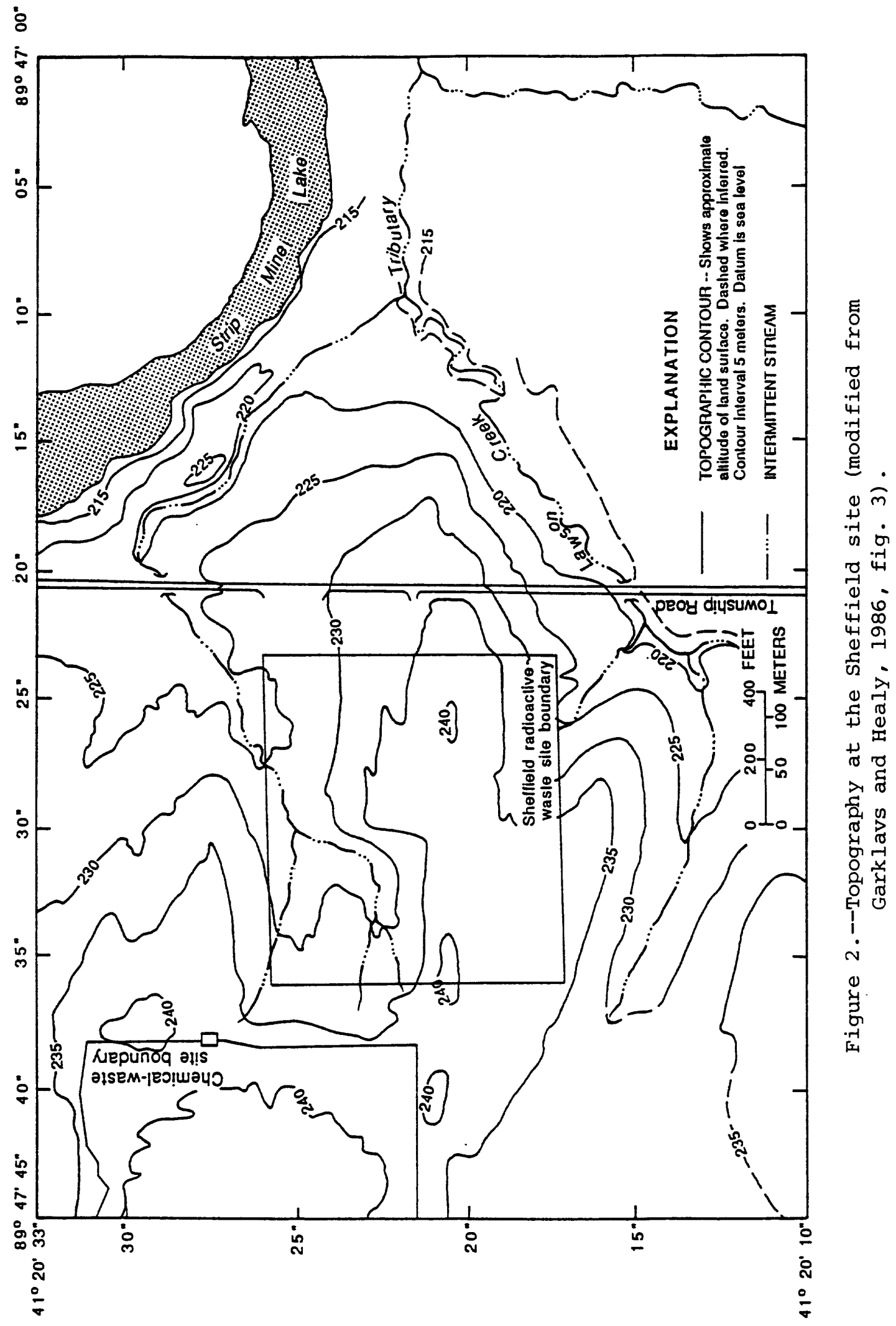




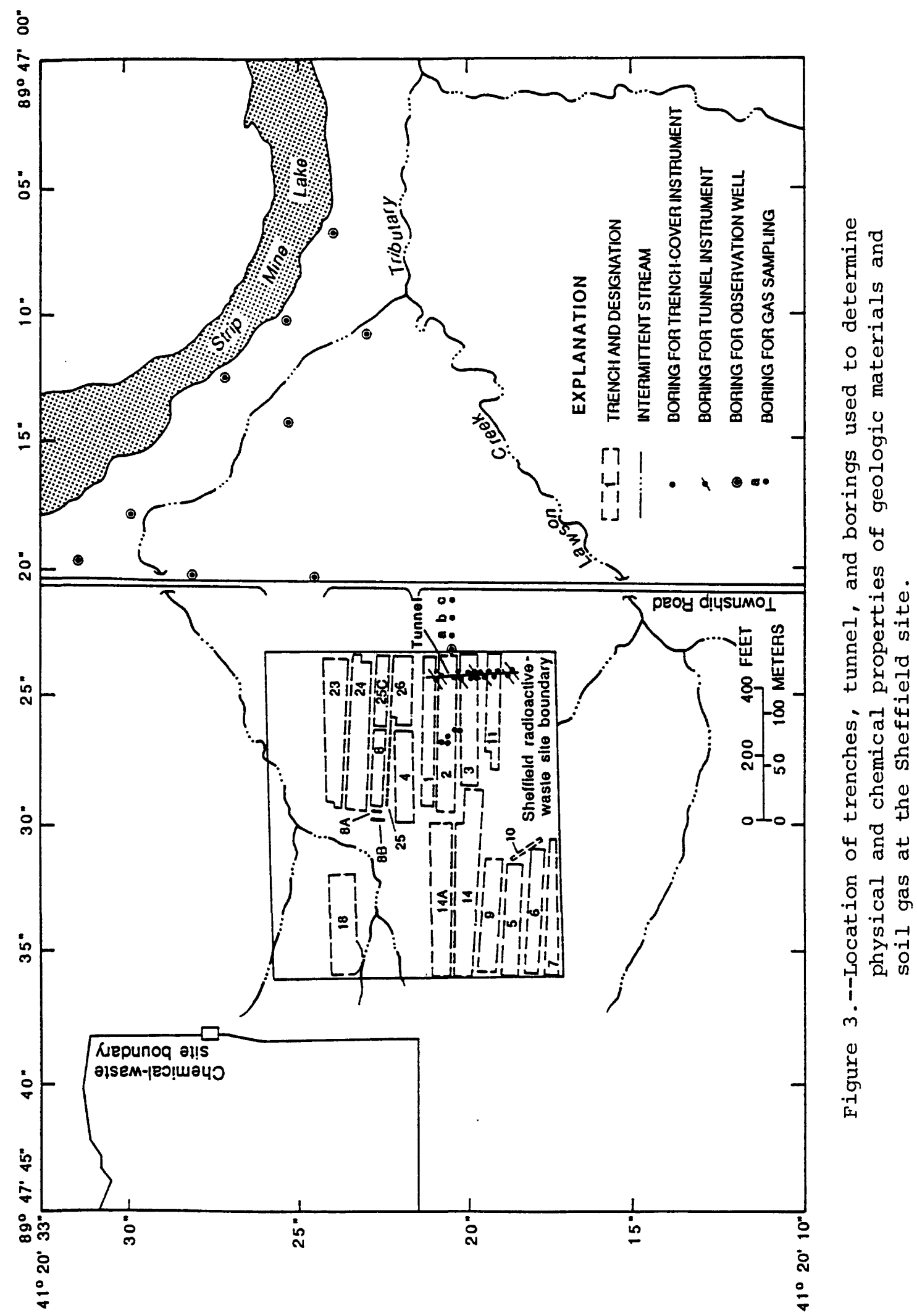




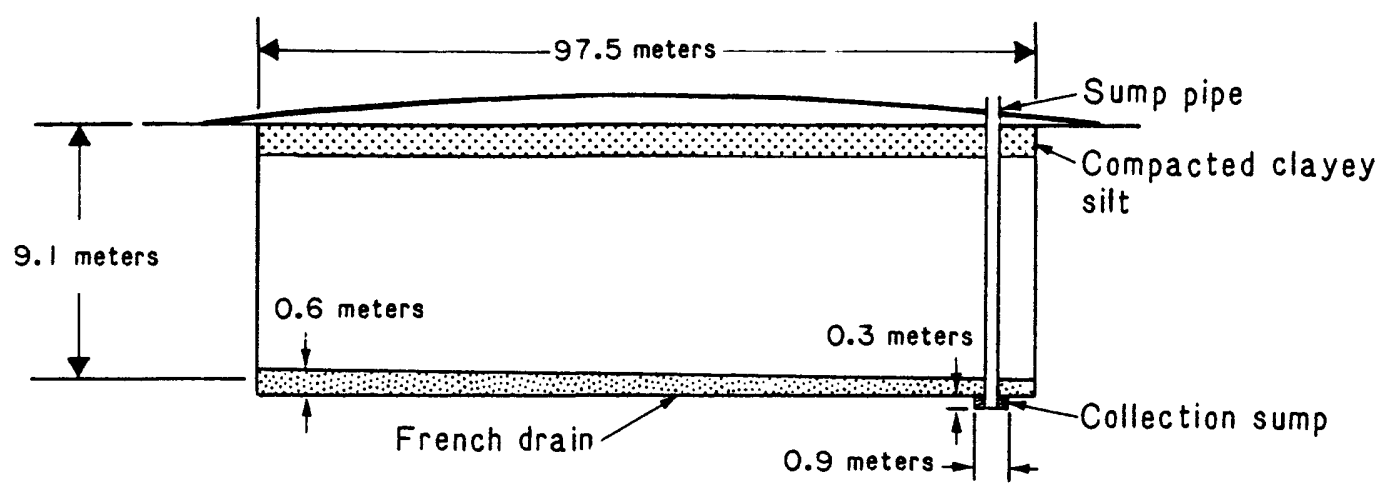

SIDE VIEW

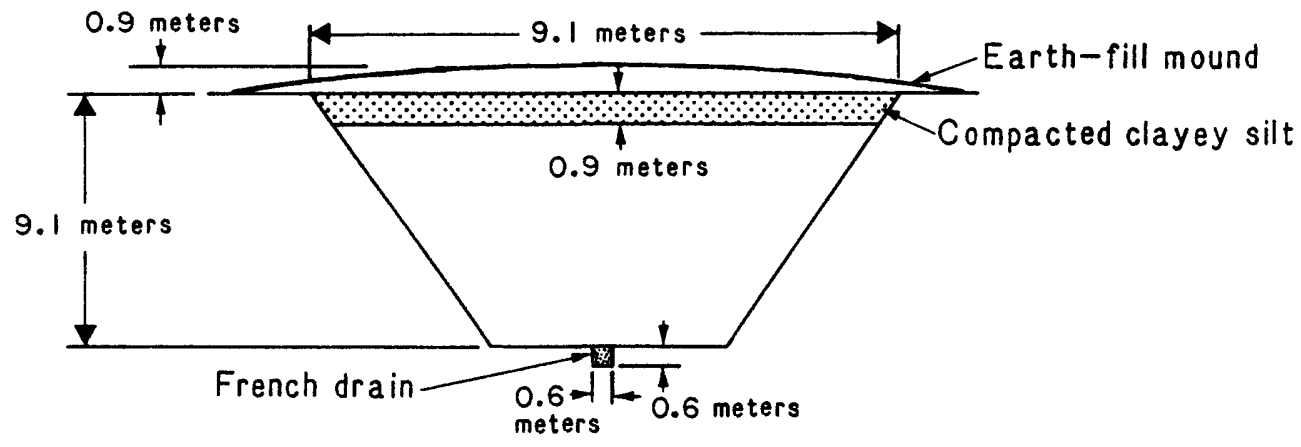

\author{
END VIEW \\ NOT TO SCALE \\ Figure 4.--Side and end views of a typical trench (modified \\ from Foster and others, 1984, fig. 4).
}

\title{
Related Studies
}

Reports on hydrology, geology, and water quality at the Sheffield site (Foster and Erickson, 1980; Foster and others, 1984, 1984a, and 1984b) provided much of the background information for this study. A Brookhaven National Laboratory study (Piciulo and others, 1982) contributed information on chemical and physical properties of geologic materials in the unsaturated zone. Other investigations of the unsaturated zone at the site concern the role of trench caps in inhibiting infiltration (Healy, 1989), the determination of evapotranspiration from trench caps (Healy and others, 1989), the modeling of unsaturated-zone water flow (Mills and Healy, 1991), and a study of gas transport (Striegl, 1988). 
Data-collection techniques used in this and other unsaturated-zone investigations at the site are described in Healy and others (1986). A tunnel originally constructed for the study by Foster and others (1984) was used to provide access for sampling directly beneath several trenches on-site. The 90-m-1ong by 2-m-diameter tunnel extends northward under the eastern ends of trenches $11,3,2$, and 1 ( $f$ ig. 3 ).

\section{$\underline{\text { Acknowledgments }}$}

The authors acknowledge the Illinois Department of Nuclear Safety for tritium analyses; the University of Illinois, Department of Geology, for analysis of carbonate mineralogy, cation-exchange capacities, petrography, and tritium concentrations; the Illinois Environmental Protection Agency for water chemistry analysis; and the Illinois State Geological survey for determination of grain-size distributions and clay mineralogy. We would like to express our appreciation to US Ecology, Inc., the firm responsible for site management, for allowing access to the site for our investigation.

\section{DESCRIPTION OF STUDY AREA}

\section{Climate}

The climate at Sheffield is continental, characterized by an average annual temperature of $10^{\circ} \mathrm{C}$ (degrees Celsius) (State of Illinois, 1958), with warm, humid summers (average temperature, $22.2^{\circ} \mathrm{C}$ ) and cold winters (average temperature, $7.5^{\circ} \mathrm{C}$ ) (Wallace, 1980, p. 26-28). Average annual precipitation computed from records of three National weather service stations located within $25 \mathrm{~km}$ of the site (fig. 1) was $890 \mathrm{~mm}$ (millimeters) for the period 1939 through 1979 (U.S. Department of Commerce, 1939-79). There is a dry period, November through March; a wet period, April through July; and a moderate period, August through October. During the study, monthly precipitation averaged $49.3 \mathrm{~mm}$ during the dry period, $107 \mathrm{~mm}$ during the wet period, and $80.8 \mathrm{~mm}$ during the moderate period. Additional information concerning precipitation and evapotranspiration can be found in Healy and others (1989).

\section{$\underline{\text { Geology }}$}

The site is located in the Galesburg Plain Division of the Till Plains Physiographic Region (Thornburn, 1963) and is characterized by Illinoian till plains that have an undulant surface. The tills have weathered zones up to 2-m thick and leached zones up to 4-m thick (Piskin and Bergstrom, 1975, p. 11-17). Present topography generally reflects the preglacial bedrock surface.

The stratigraphic nomenclature used in this report is that of the Illinois State Geological Survey (Willman and Frye, 1970, p. 12) and does not necessarily follow the usage of the U.S. Geological Survey. Figure 5 shows the time-stratigraphic and rock-stratigraphic classification. 


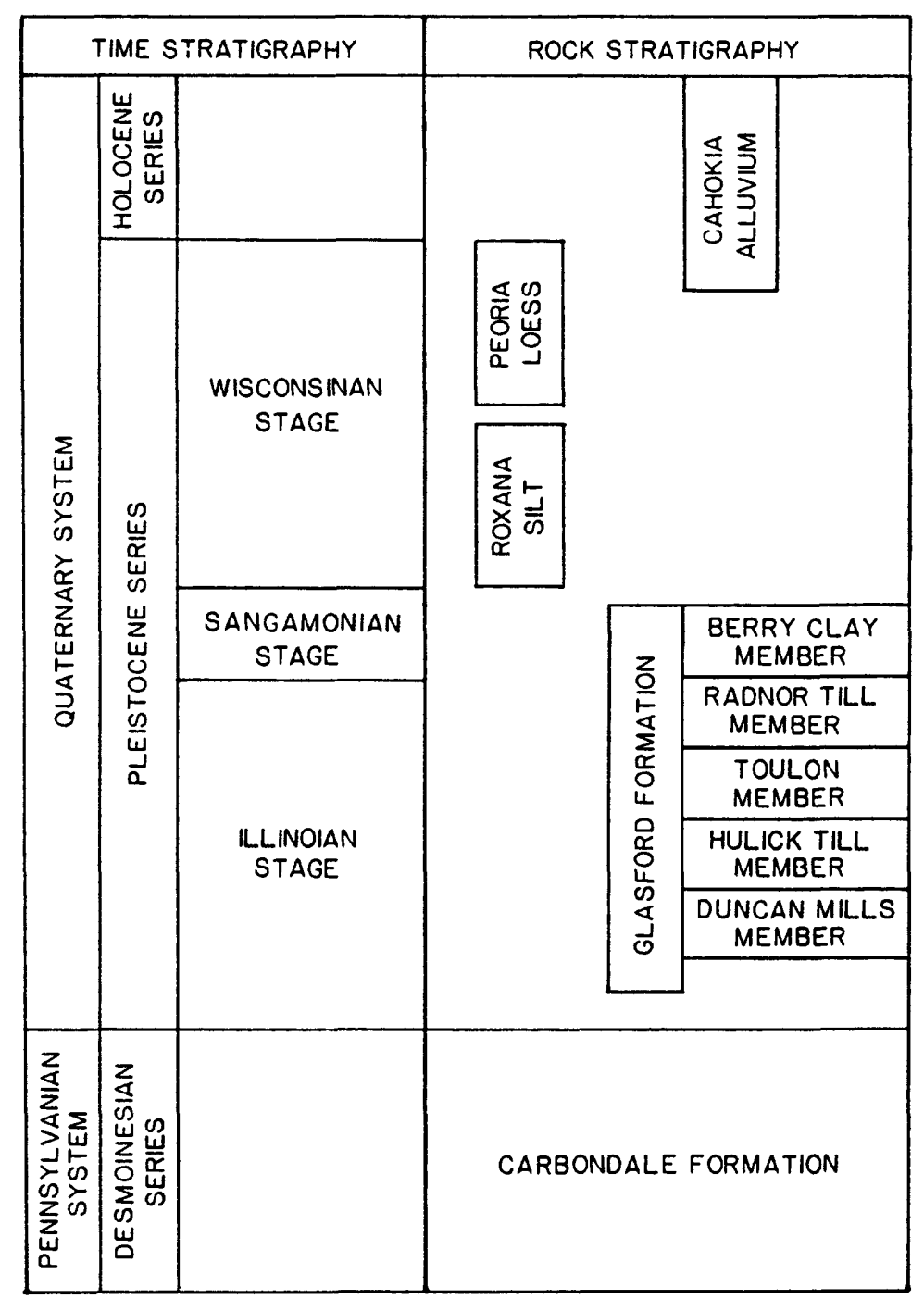

Figure 5.--Time-stratigraphic and rock-stratigraphic classification of the Illinois State Geological Survey (modified from Willman and Frye, 1970, fig. 1).

Quaternary deposits form the unconsolidated geologic cover and vary in thickness from 3 to $28 \mathrm{~m}$. These deposits include eight rock-stratigraphic units (fig. 5) (Foster and others, 1984) that range in lithology from a silty clay to a pebbly sand. Areal and vertical distribution of these units varies greatly across the site (figs. 7 and 8 , lines of section in fig. 6). The units overlie about $140 \mathrm{~m}$ of bedrock composed of fossiliferous shale, coal, and mudstone of the Pennsylvanian Carbondale Formation (H. W. Smith, Illinois State Geological Survey, written commun., 1966).

The oldest Quaternary deposit at the Sheffield site (fig. 5) is the Pleistocene Duncan Mills Member of the Glasford Formation (Willman and Frye, 1970, p. 12) that consists of silt interbedded with silty clay and some pebbly 


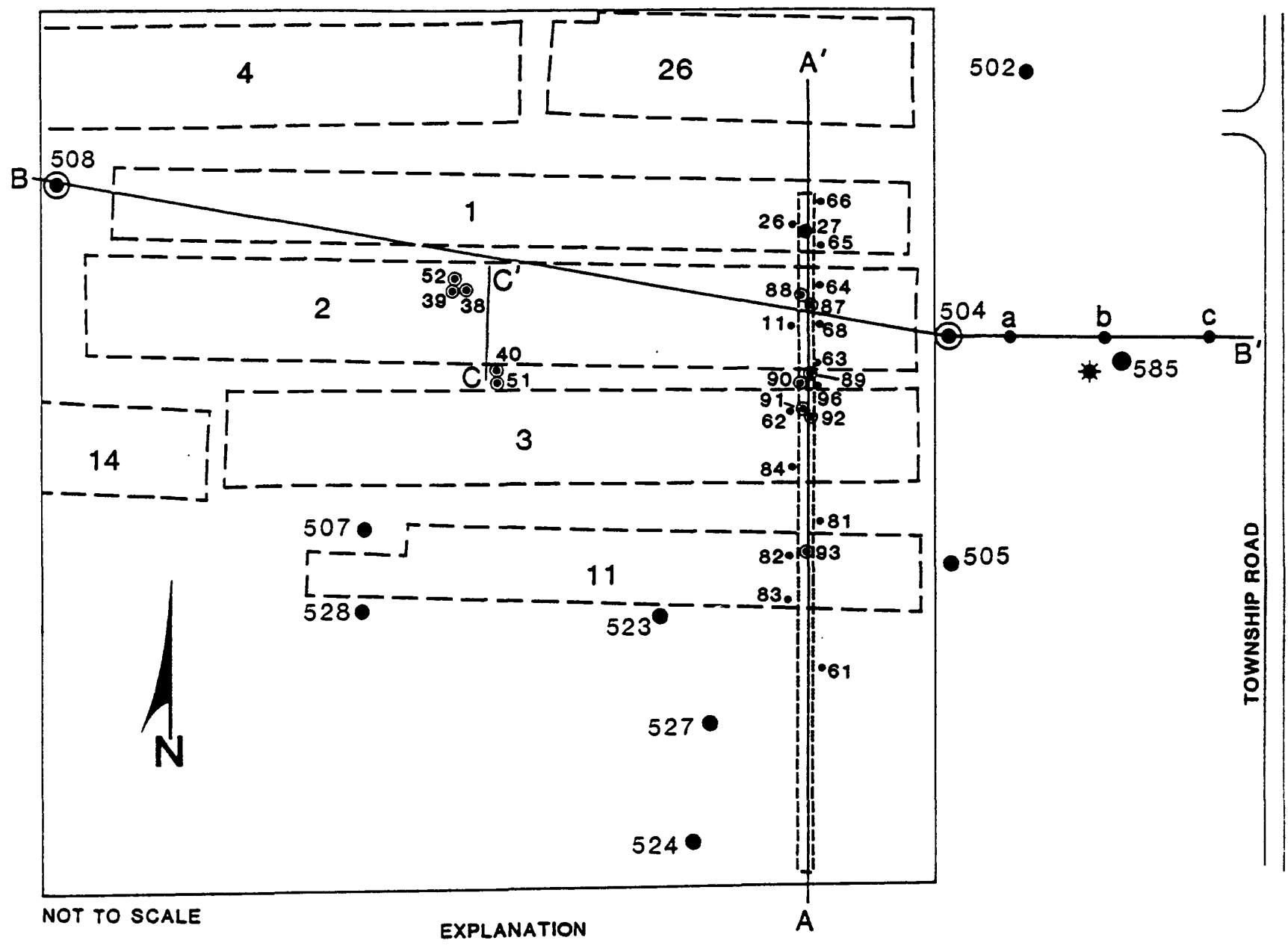

WELL AND DESIGNATION 502 Well sampled in study $0^{508}$ well used for geologic control in cross-section PRESSURE-VACUUM
LYSIMETER AND DESIGNATION
51 AbOVe-trench
65 Below-trench
585 Oft-site

Figure 6.--Location of lines of section, lysimeters, wells, and precipitation collector. 


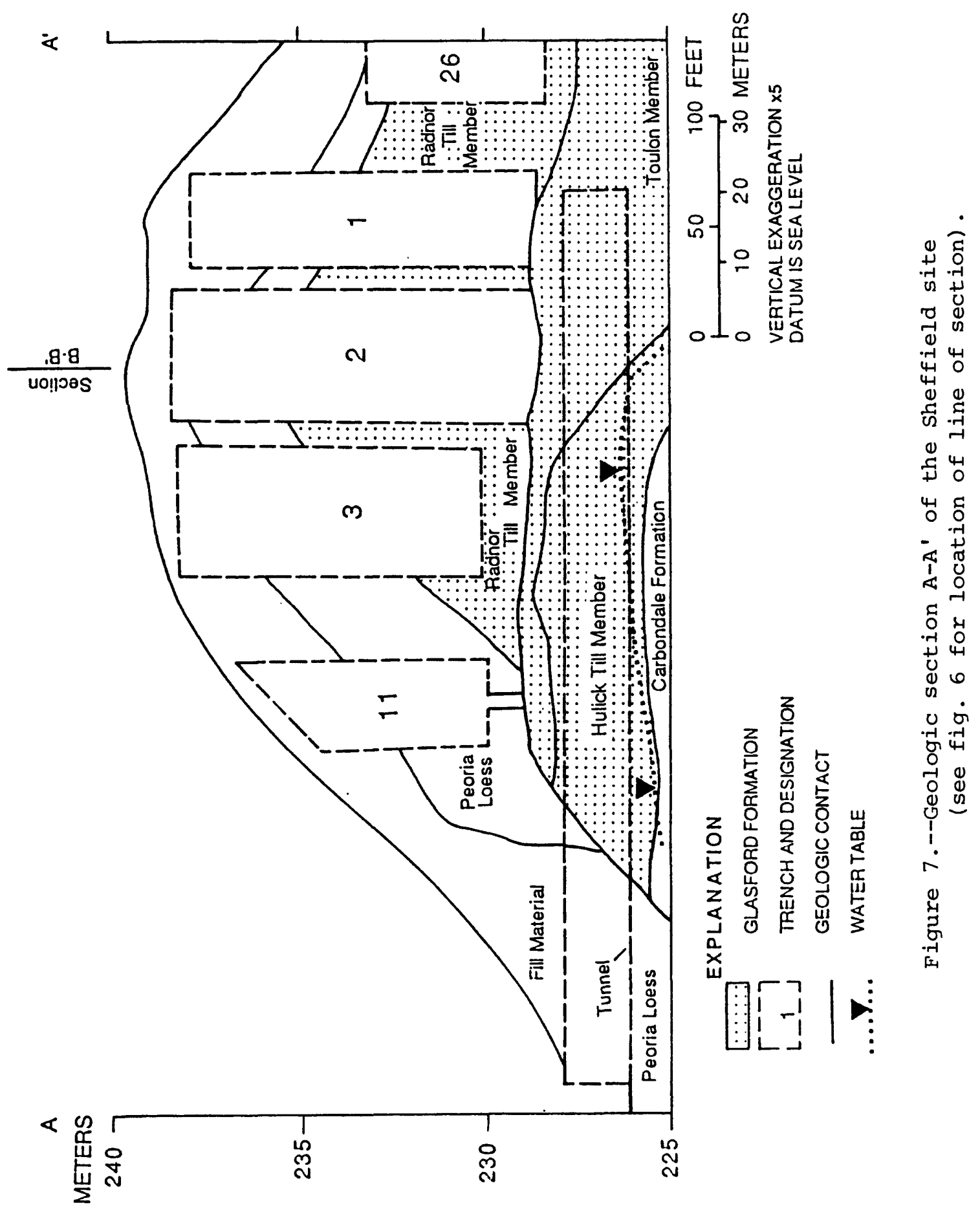




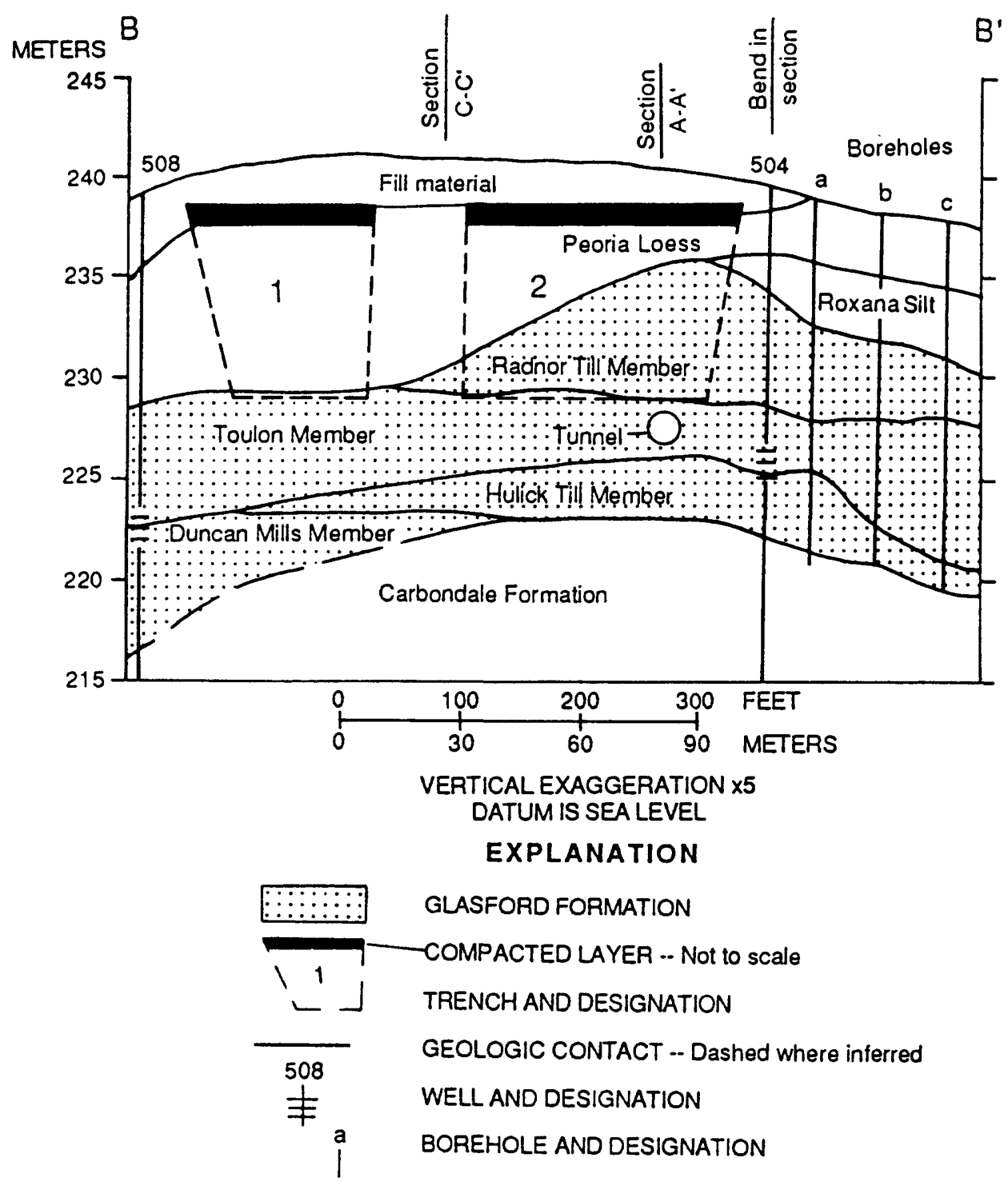

Figure 8.--Geologic section $B-B$ ' of the Sheffield site (see fig. 6 for location of line of section).

silty sand layers. The next oldest unit is the Hulick Till Member of the Glasford Formation. The textural composition of the Hulick Till Member ranges from clayey silt to sandy silty clay.

The Toulon Member of the Glasford Formation, a channel-like outwash deposit, consists of a well-sorted, pebbly sand grading to a pebbly silty sand. The Radnor Till Member of the Glasford Formation, present only in the southern half of the site, consists of a clayey silt or a sandy silty clay (Foster and others, 1984, p. 14). The Berry Clay Member of the Glasford Formation is an accretion-gley deposit; because it is restricted to a few locations in the western part of the site, it was not evaluated in this study. 
During the Wisconsinan, glacial ice did not cover the Sheffield site; eolian and other postglacial materials were deposited there. Wisconsinan eolian deposits are designated as the Roxana silt and the Peoria Loess. Deposition of Cahokia Alluvium, a sandy silt, began in the Wisconsinan and extended into the Holocene; because it is restricted to the northeastern corner of the site, it was not evaluated in this study.

The last major soil development began in the Holocene and continues to the present. This soil is developed in the upper part of the Peoria Loess and has been designated as Modern soil. The uppermost layer of material at the site is the fill material, brought in for construction of trench caps and to fill low areas. Composition of the fill ranges from silt to silty clay (Foster and others, 1984, p. 15).

\section{Hydrology}

The average annual precipitation measured at the site for the period July 1982 through June 1984 was $948 \mathrm{~mm}$ (Mills and Healy, 1991). Mills and Healy (1991) also estimated that average annual evapotranspiration was $657 \mathrm{~mm}$, runoff was $220 \mathrm{~mm}$, and recharge to the unsaturated and/or saturated zone was $131 \mathrm{~mm}$. Runoff that originates on the site drains to Lawson Creek, about 1.6 $\mathrm{km}$ east of the site (fig. 9).

Ground water in the Pleistocene deposits flows to the east and discharges to a strip-mine lake $0.4 \mathrm{~km}$ from the site (fig. 9). Ground-water flow is primarily within the pebbly sand of the Toulon Member. Altitude to the saturated zone ranges from 8 to $16 \mathrm{~m}$ and is highly variable. The altitude of the water table beneath the study area changes by as much as $6 \mathrm{~m}$ over a distance of $60 \mathrm{~m}$.

All of the Quaternary deposits that have been identified at the site are present within the unsaturated zone. All trenches, with the possible exception of trench 18, were constructed entirely within the unsaturated zone.

Percolation of water to the saturated zone generally occurs only during spring. The rest of the year there is less water movement in the unsaturated zone because of frozen ground and low precipitation in the winter, high evapotranspiration during the summer, and moderate precipitation during the fall.

Water movement through the unsaturated zone is complex because of seasonal variations of precipitation and evapotranspiration, physical heterogeneity of the waste trenches, and variability in areal distribution and physical character of the unconsolidated surficial deposits. The direction of water movement within the unsaturated zone is primarily downward. The layering of the different geologic units affects the direction as well as the rate of water (Mills and Healy, 1987). Sloping interfaces between geologic units, as shown in figure 10, may function as preferential pathways, adding a horizontal component to unsaturated-zone flow. Throughout the length of the tunnel, the sand-silt-clay Hulick Till Member is overlain by well-sorted, medium-grained sand of the Toulon Member. The saturated hydraulic conductivity for the sand is about three orders of magnitude greater than for the till (Foster and others, 1984, p. 18), and the interface between the sand and 


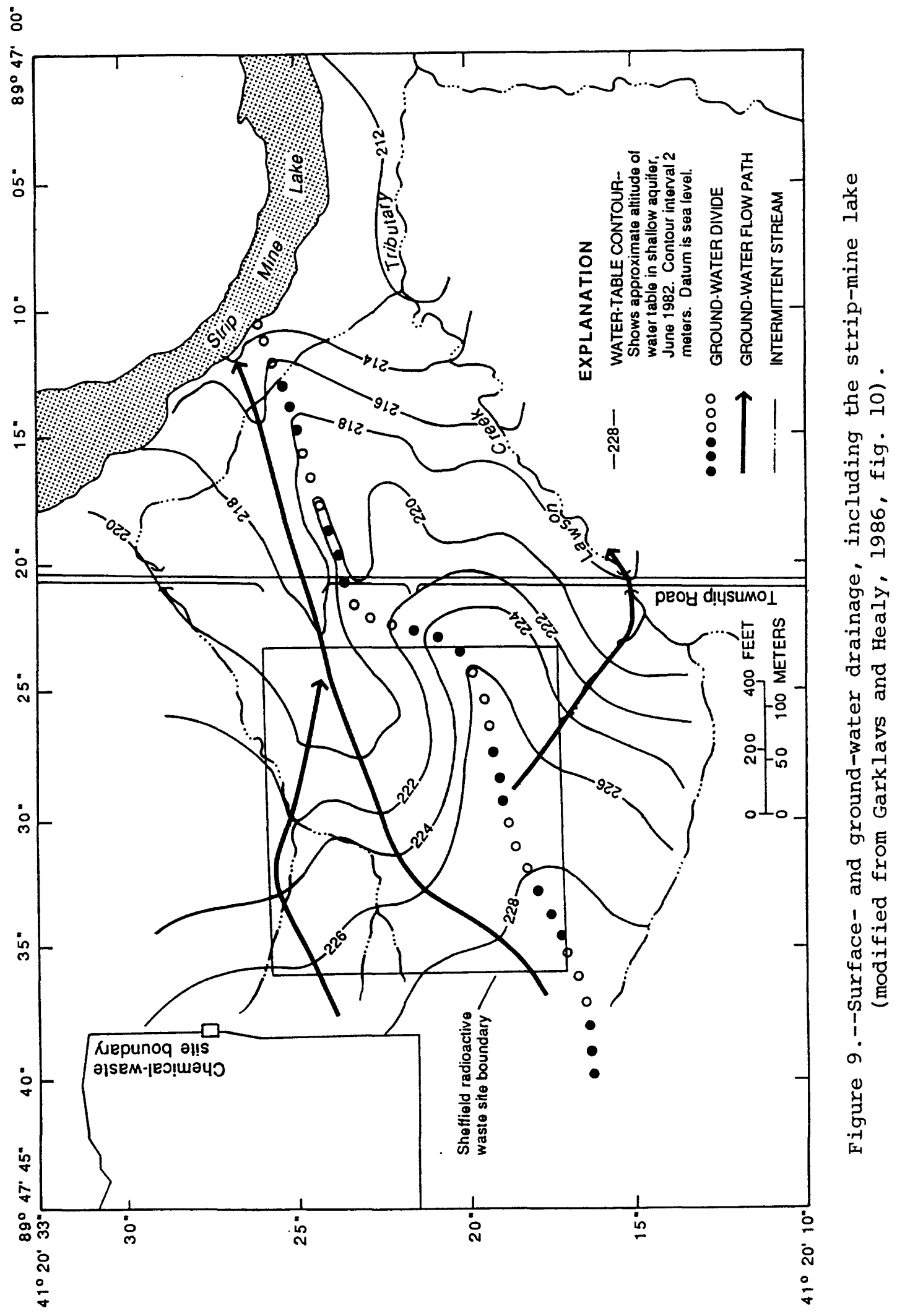




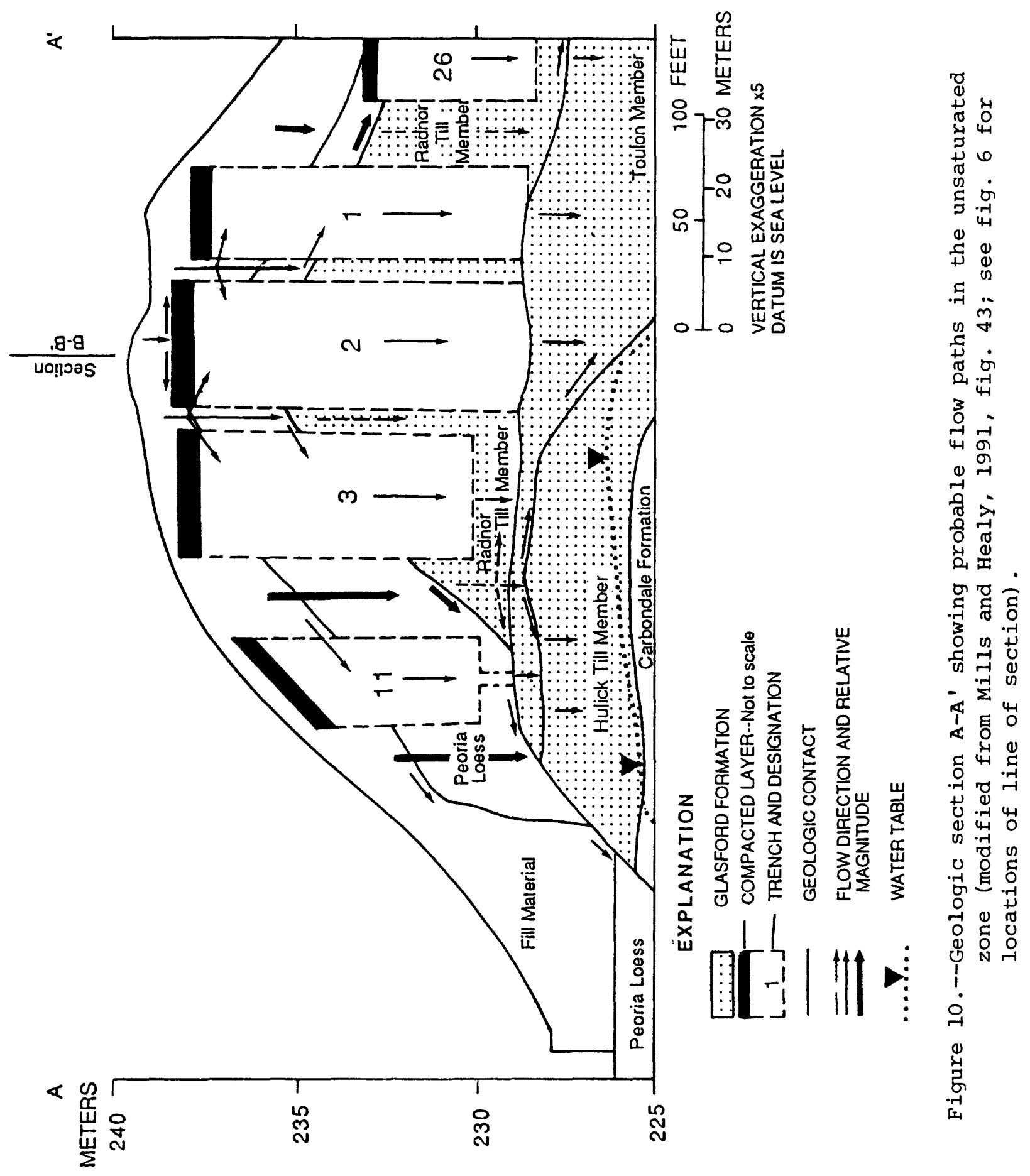


till units has a steep slope near the north end of the tunnel (fig. 10). Because the hydraulic conductivity for the till is much less than for the $s$ and, the water content of the sand becomes nearly saturated at the interface and water tends to move along the interface instead of through the till (Foster and others, 1984, p. 17). The effects of interfaces between other units are more difficult to interpret because the differences in hydraulic conductivity are smaller and interface slopes are not nearly as steep as for the sand/till interface. Figure 10 also shows probable flow paths for water movement through the unsaturated zone at geologic section A-A'. Ground-water flux along each of these paths was not quantified.

\section{METHODS OF INVESTIGATION}

\section{Collection and Analysis of Geologic Materials}

Physical and chemical properties of geologic materials were determined from core samples removed during the drilling of boreholes and the installation of sampling equipment. Physical properties tested included particle-size distributions, surface area, bulk density, and porosity. Chemical properties tested were carbonate and clay mineralogies; petrography of fine sands; cationexchange capacity; exchangeable calcium, magnesium, and iron concentrations; $\mathrm{pH} ;$ and percent organic content. Geologic materials were analyzed according to methods outlined in table 1. Figure 3 shows locations where samples were collected for analyses of physical and chemical properties.

Samples of fill material, Peoria Loess, and the Toulon Member and Hulick Till Member of the Glasford Formation were obtained during installation of many of the lysimeters and were analyzed for the above-listed physical properties and gross alpha and beta radiation. Gamma-spectral analyses for non-naturally occurring gamma-emitting radionuclides and high concentrations of naturally occurring gamma-emitters were performed on four cores collected from between the top of the tunnel and the bottom of trenches 2 and 3 .

Samples of fill material, Peoria Loess, Roxana Silt, Radnor Till Member of the Glasford Formation, and Toulon Member from nine different well borings (Foster and others, 1984b) were analyzed for particle-size distribution, mineralogic composition, clay mineralogy, and cation-exchange capacity. Samples of Peoria Loess, Roxana Silt, Radnor Till Member, Toulon Member, and Hulick Till Member also were analyzed for cation-exchange capacity, pH, calcium, magnesium, iron, and percent iron, percent carbonates, and percent organic matter (Piciulo and others, 1982).

Samples of geologic materials were obtained by driving 25-, 50-, or 75-mm-diameter sampling tubes into sediments and by using split-spoon samplers. Samples were removed from the tubes by extrusion or by cutting the tube lengthwise (Healy and others, 1986, p. 29).

Sample-collection procedures can introduce substantial error in physical and chemical measurements. Stainless-steel samplers were used to prevent chemical reactions that may occur between wet soils and samplers. Cores were sealed from the atmosphere during storage to prevent loss of water by evaporation. 
Table 1.--Laboratory procedures for analyses of physical and chemical properties of geologic materials

\begin{tabular}{|c|c|c|c|}
\hline Property : & Analytical method & Reference & Agency ${ }^{l}$ \\
\hline Particle size & Pipette & Day, 1965 & $\begin{array}{l}\text { ISGS, USGS, } \\
\text { UI Geo. }\end{array}$ \\
\hline Bulk density & Core & Blake, 1965 & USGS IL Dist. \\
\hline $\begin{array}{l}\text { Carbonate } \\
\text { mineralogy }\end{array}$ & Chittick analysis & Dreimanis, 1962 & $\begin{array}{l}\text { BNL, UW Geo., } \\
\text { UI Geo. }\end{array}$ \\
\hline $\begin{array}{l}\text { Clay } \\
\text { mineralogy }\end{array}$ & $\mathrm{x}$-ray diffraction & $\begin{array}{l}\text { Hurlbut and } \\
\text { Klein, } 1977\end{array}$ & ISGS \\
\hline $\begin{array}{l}\text { Total } \\
\text { mineralogy }\end{array}$ & $\begin{array}{l}\text { Petrographic } \\
\text { analysis }\end{array}$ & $\begin{array}{l}\text { Hurlbut and } \\
\text { Klein, } 1977\end{array}$ & UI Geo. \\
\hline $\mathrm{pH}$ & $\begin{array}{l}\text { 1: } 1 \text { distilled water } \\
\text { to soil mixture }\end{array}$ & $\begin{aligned} & \text { Pietrzak and } \\
& \text { Dayal, } 1982\end{aligned}$ & BNL \\
\hline $\begin{array}{l}\text { Organic } \\
\text { matter }\end{array}$ & Ignition & Broadbent, 1973 & BNL \\
\hline Soluble ions & $\begin{array}{l}\text { x-ray flourescence, } \\
\text { Neutron activation, } \\
\text { Atomic adsorption, } \\
\text { Gravimetric }\end{array}$ & $\begin{aligned} \text { Pietrzak and } \\
\text { Dayal, } 1982\end{aligned}$ & BNL \\
\hline Gamma spectral & $\begin{array}{l}\text { Gamma-ray } \\
\text { spectrometry }\end{array}$ & Crouthamel, 1970 & $\begin{array}{l}\text { USGS IL Dist., } \\
\text { UI ERL }\end{array}$ \\
\hline $\begin{array}{l}\text { Cation exchange } \\
\text { capacity }\end{array}$ & Ammonium displacement & Chapman, 1965 & $\begin{array}{l}\text { USGS, BNL, } \\
\text { UI Geo. }\end{array}$ \\
\hline \multirow[t]{2}{*}{ Porosity } & Calculated $\left(\mathrm{BD} / \mathrm{SPD}^{2}\right)$, & $\begin{array}{l}\text { Freeze and } \\
\text { Cherry, } 1979\end{array}$ & USGS IL Dist. \\
\hline & Mercury porsimeter & Vomocil, 1965 & USGS \\
\hline Surface area & $\begin{array}{l}\text { Nitrogen adsorption } \\
\text { by Monosorb analyzer }\end{array}$ & $\begin{array}{l}\text { Brunaer, Enmett, } \\
\text { and Teller, } 1938\end{array}$ & USGS NRP \\
\hline
\end{tabular}

1 ISGS - Illinois State Geological Survey; UI Geo. - University of Illinois Geology Department; USGS - U.S. Geological Survey laboratory at Denver, Colorado; USGS II Dist. - U.S. Geological Survey laboratory at Urbana, Illinois; BNL - Brookhaven National Laboratory; UW Geo. - University of Wisconsin Geology Department; UI ERL - University of Illinois Environmental Resources Laboratory; and USGS NRP - U.S. Geological Survey laboratory at Reston, Virginia.

2 BD/SPD - Bulk density/Standard particle density of 2.65 grams per cubic centimeter. 


\section{Collection and Analysis of Water Samples}

Water samples were collected from a rain collector, pore-water pressurevacuum lysimeters, ground-water observation wells, and soil cores. Specific conductance, pH, alkalinity, and concentrations of major cations, anions, dissolved organic carbon ( $D O C)$, gross alpha and beta radiation, and tritium were measured in water samples. Tritium is a radioisotope of hydrogen that decays by pure beta emission and has a half life of 12.3 years.

\section{Water Analysis}

Specific conductance was measured in the field for all sample volumes greater than $10 \mathrm{~mL}$ (milliliters). Measurements of $\mathrm{pH}$ in water were made in the field using a pH meter and combination glass electrode (Skougstad and others, 1979, p. 543). Mean pH values were derived by converting pH units to hydrogen-ion concentrations, determining mean concentrations, and converting the means back to $\mathrm{pH}$ units.

Alkalinity was determined by incremental electrometric titration (Barnes, 1964 , p. 17) using 5 to $100 \mathrm{~mL}$ of sample. For the range in pH that was measured, titrated alkalinity was assumed to be bicarbonate-ion alkalinity.

Major ions, metals, and DOC were analyzed at the Illinois Environmental Protection Agency (IEPA) lab using methods described by IEPA (1982) and at the U.S. Geological Survey National water Quality Laboratory in Doraville, Georgia, using methods described by Skougstad and others (1979). Samples for metals analysis were acidified in the field with nitric acid to a $\mathrm{pH}$ of 2 and were kept chilled. Samples for DOC analysis were filtered through a silver filter in the field using a stainless-steel filter chamber. Dissolved-organic-carbon samples were kept chilled and dark until analyzed.

Gross alpha and beta radiation were measured with a NMC Model PC-5 gas proportional counter (Nuclear Measurements Corporation, 1975). Tritium concentrations were measured by liquid scintillation (Thatcher and others, 1977, p. 63-71). Two counts of 200 minutes each were made of each sample, using a Beckman LS100 scintillation counter. Duplicate counts, analyses of replicate samples by other labs, and longer-than-recommended count periods were employed for quality control.

The limit of detection of tritium by the liquid scintillation counting method is about $0.2 \mathrm{nCi} / \mathrm{L}$ (nanocuries per liter) (62.1 tritium units) (Thatcher and others, 1977, p. 79); this value is considered to be the background concentration of tritium at the Sheffield site. The accuracy of the method used for tritium analysis did not allow determination of actual tritium concentrations; the method did allow distinguishing between values at \pm 10 percent.

\footnotetext{
IUse of brand names in this report is for identification purposes only and
} does not constitute endorsement by the U.S. Geological survey. 
Precipitation samples were collected using a stainless-steel rain collector with a $300-\mathrm{mm}$ opening on top that drained immediately into a polyethylene bottle (Brackensiek and others, 1979, p. 32-36). The collector was located at a height of $2.5 \mathrm{~m}$ above land surface near borehole 585 (fig. 6). The precipitation-collection system was cleaned with laboratory-glassware detergent and rinsed thoroughly with distilled water before each sample was collected. Samples were collected from six rainstorms between June and December 1983. Specific conductance, $\mathrm{pH}$, alkalinity, and tritium concentrations were measured for all samples, and major ions were analyzed for three samples.

High values of $z$ inc in precipitation samples suggested possible contamination problems. To determine if the samples were contaminated with $z$ inc by the collection apparatus, distilled water (pH 5.9) was poured through the apparatus and then analyzed for zinc. The average concentration of zinc in these samples was $40 \mu \mathrm{g} / \mathrm{L}$ (micrograms per liter) as compared to an average zinc concentration in rain water of $1,300 \mu \mathrm{g} / \mathrm{L}$.

\section{Collection of Water Samples from the Unsaturated zone}

Pore-water pressure-vacuum lysimeters (vacuum lysimeters) were used to collect pore-water samples from the unsaturated zone. Vacuum lysimeters consist of a porous-ceramic cup attached to one end of a cylinder that has an air-tight plug fitted in its other end. Two tubes lead through the plug into the cylinder, with one ending near the plug and the other ending proximal to the base of the cup. The tubes lead to land surface where each is terminated with a gas-tight valve (fig. 11). To collect water, a vacuum that exceeds the existing soil-water tension is applied to the lysimeter (Healy and others, 1986 , p. 28). The resulting pressure gradient causes water to flow through the ceramic cup into the lysimeter. Pore-water samples are withdrawn by opening the valves on the access tubes and applying positive pressure with compressed nitrogen gas to the upper tubing, forcing water up the lower access tube and out of the lysimeter. Details of construction and installation of vacuum lysimeters are described by Healy and others (1986). Pore-water samples are filtered as they pass through the lysimeter cup; therefore, only dissolved fractions were measured.

Vacuum lysimeters allow numerous samples to be obtained from the same location at a relatively inexpensive cost. There are several problems inherent in their operation. These include (1) the materials that lysimeters are constructed of can contribute constituents to, or remove constituents from, the sample obtained; (2) the application of suction to retrieve lysimeter samples can change the natural pore-drainage rate or sample an area rather than a point; and (3) the application of suction can change the chemical equilibria of the sample as it is drawn into the lysimeter.

The porous-ceramic cup has been shown to contribute several milligrams per liter of calcium, magnesium, sodium, bicarbonate, and silica to water samples (Wolfe, 1967) and to reduce dissolved-metals concentrations in samples by as 


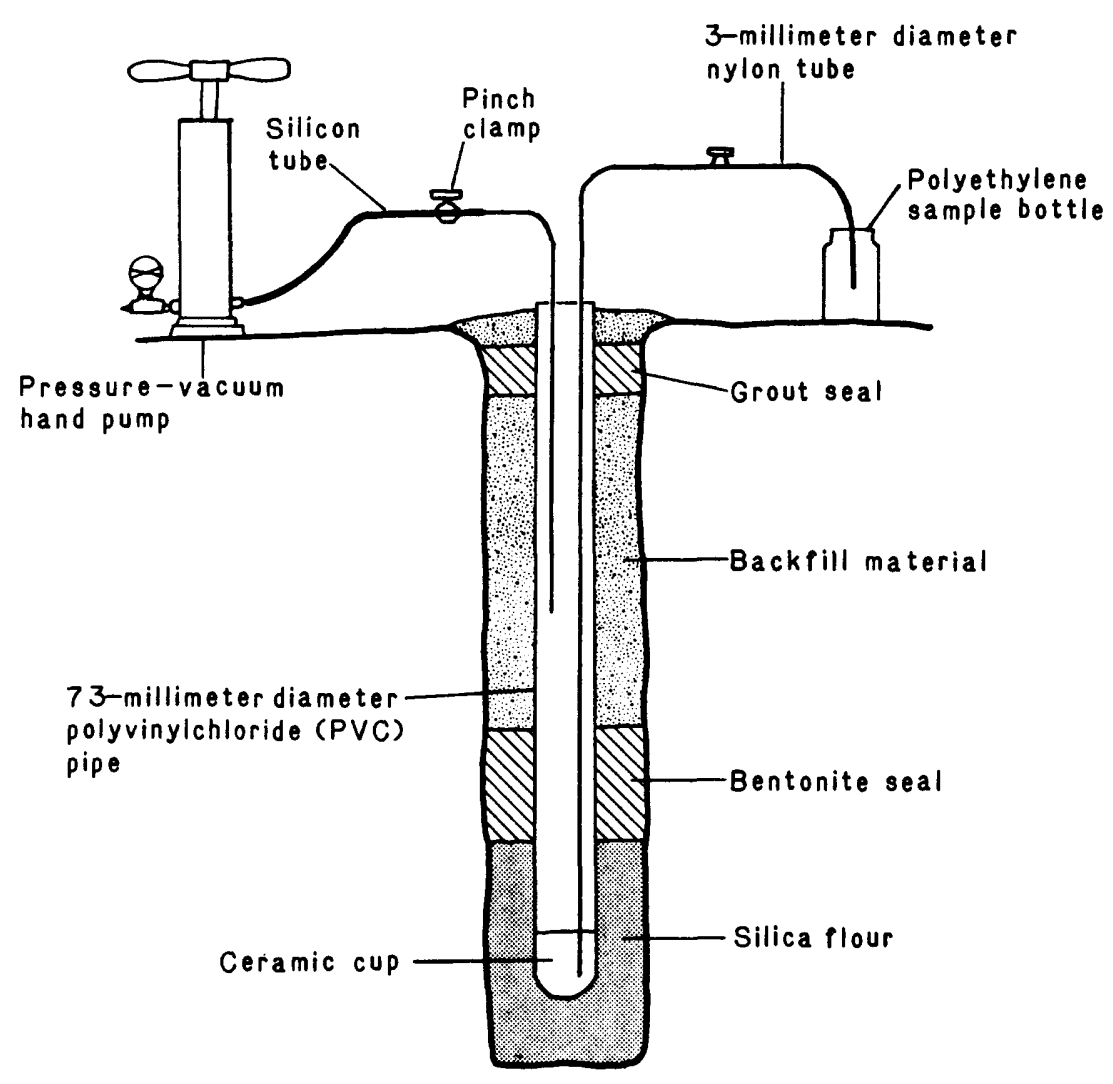

NOT TO SCALE

\begin{abstract}
Figure 11.--Typical installation of pore-water pressure-vacuum lysimeter.
\end{abstract}

much as 5 to 10 percent (Tsai and others, 1980). To avoid similar uncertainties, lysimeter cups used in this study were leached with hydrochloric acid and rinsed with distilled water until the specific conductance of distilled water drawn through the cups did not increase. The effect of the leached cups on water chemistry was tested by drawing a water sample of known constituent concentrations through a leached cup and analyzing the sample. The known water concentrations, leached-cup water sample concentrations, and the percent changes between the two are shown in table 2. The analyses indicated that although major ions were only slightly altered, metals concentrations were subject to large changes.

The potential for contamination of samples by other lysimeter materials (polyvinyl chloride, brass, stainless steel, and galvanized metal) also was investigated by comparing chemical analyses from similarly situated lysimeters constructed with the various materials. Results indicated that the use of galvanized materials in lysimeter construction may have an effect on concentrations of zinc and manganese (table 3 ). Concentrations of zinc and manganese from lysimeters constructed with some galvanized material averaged 50 percent and 160 percent higher, respectively, than concentrations from lysimeters constructed without galvanized materials. The use of other materials in lysimeter construction showed no noticeable effects. 
Table 2.--Concentrations of selected constituents for a known water sample, for the known sample collected through a leached porous-ceramic cup, and the percent difference between the concentrations

[mg/L, milligrams per liter; $\mu \mathrm{g} / \mathrm{L}$, micrograms per liter]

\begin{tabular}{lrcc}
\hline & $\begin{array}{l}\text { Known } \\
\text { S ample }\end{array}$ & $\begin{array}{c}\text { Sample collected } \\
\text { through leached } \\
\text { ceramic cup }\end{array}$ & $\begin{array}{c}\text { Percent } \\
\text { difference }\end{array}$ \\
\hline Calcium & $33 \mathrm{mg} / \mathrm{L}$ & $34 \mathrm{mg} / \mathrm{L}$ & +3 \\
Magnesium & $15 \mathrm{mg} / \mathrm{L}$ & $18 \mathrm{mg} / \mathrm{L}$ & +20 \\
Sodium & $57 \mathrm{mg} / \mathrm{L}$ & $58 \mathrm{mg} / \mathrm{L}$ & +2 \\
Sulfate & $54 \mathrm{mg} / \mathrm{L}$ & $59 \mathrm{mg} / \mathrm{L}$ & +9 \\
Chloride & $67 \mathrm{mg} / \mathrm{L}$ & $72 \mathrm{mg} / \mathrm{L}$ & +7 \\
Cadmium & & $7 \mu \mathrm{Lg} / \mathrm{L}$ & -81 \\
Copper & $36 \mu \mathrm{g} / \mathrm{L}$ & $40 \mu \mathrm{L} / \mathrm{L}$ & -31 \\
Iron & $58 \mu \mathrm{L} / \mathrm{L}$ & $19 \mu \mathrm{L} / \mathrm{L}$ & -78 \\
Manganese & $330 \mu \mathrm{L} / \mathrm{L}$ & $16 \mu \mathrm{L} / \mathrm{L}$ & +51 \\
Strontium & $73 \mu \mathrm{L} / \mathrm{L}$ & $80 \mu \mathrm{L} / \mathrm{L}$ & +110 \\
Zinc & $53 \mu \mathrm{L} / \mathrm{L}$ & $88 \mu \mathrm{L} / \mathrm{L}$ & \\
\hline
\end{tabular}

Table 3.--Mean concentrations of selected metals in water samples collected using lysimeters that contain, and that do not contain, galvanized materials

[All mean values are in micrograms per liter]

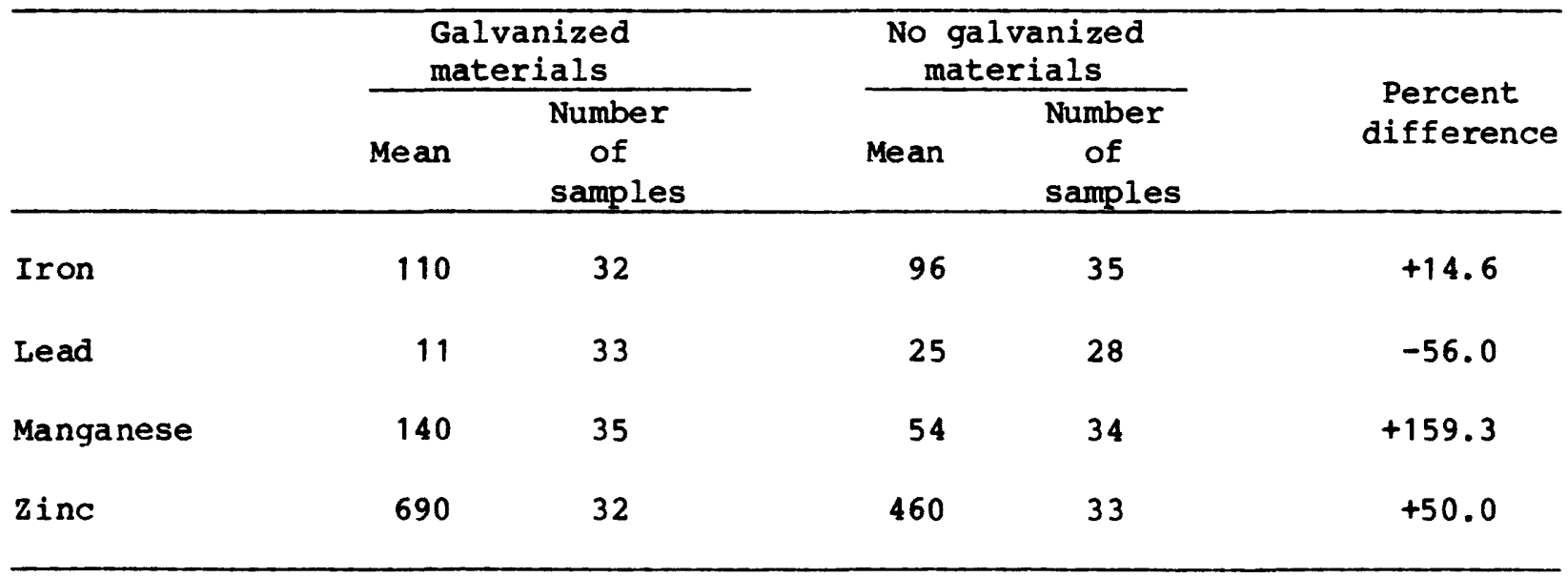


During installation, the borehole annulus surrounding the lysimeter cups was packed with silica flour to reduce clogging by finer soil particles and to ensure good contact between the cup and the surrounding geologic material. To test the effect of silica flour on water chemistry, one lysimeter was installed without silica flour. Chemical analyses of water from the control and the silica-packed lysimeters were similar. In a laboratory study, water collected from well 505, distilled water, and distilled water acidified with sulfuric acid to pH 2.7 were mixed with silica flour, filtered, and analyzed for specific conductance, pH, alkalinity, and chloride. Those measurements, and measurements for aliquots of the same waters not mixed with silica flour, are listed in table 4. Results indicate that water mixed with silica flour was very similar to untreated water for the four constituents. Although silica was not quantitatively evaluated, the use of ceramic-cup lysimeters did appear to result in elevated concentrations of silica in the water samples.

Table 4.--Values of specific conductance, $\mathrm{pH}$, alkalinity (as $\mathrm{CaCO}_{3}$ ), and chloride for untreated and for silica-saturated solutions from well 505, distilled water, and distilled water acidified to $\mathrm{pH} 2.7$ with sulfuric acid

[Specific conductance in microsiemens per centimeter at 25 degrees celsius; $\mathrm{pH}$ in standard units; alkalinity and chloride in milligrams per liter; $<$, less than]

\begin{tabular}{|c|c|c|c|}
\hline & & Untreated & $\begin{array}{l}\text { Saturated with } \\
\text { silica flour }\end{array}$ \\
\hline Well 505 & $\begin{array}{l}\text { Specific } \\
\quad \text { conductance } \\
\text { pH } \\
\text { Alkalinity } \\
\text { Chloride }\end{array}$ & $\begin{array}{c}1,260 \\
7.4 \\
420 \\
<17\end{array}$ & $\begin{array}{r}1,140 \\
7.9 \\
420 \\
3\end{array}$ \\
\hline & $\begin{array}{l}\text { Specific } \\
\text { conductance }\end{array}$ & 0 & 12 \\
\hline $\begin{array}{l}\text { Distilled } \\
\text { water }\end{array}$ & $\begin{array}{l}\text { pH } \\
\text { Alkalinity } \\
\text { Chloride }\end{array}$ & $\begin{aligned} & 6.1 \\
& 4 \\
&<10\end{aligned}$ & $\begin{array}{l}6.1 \\
4 \\
3\end{array}$ \\
\hline $\begin{array}{l}\text { Distilled } \\
\text { water } \\
\text { acidified } \\
\text { to pH } 2.7\end{array}$ & $\begin{array}{l}\text { Specific } \\
\text { conductance } \\
\text { pH } \\
\text { Alkalinity }\end{array}$ & $\begin{array}{l}620 \\
2.7 \\
0 \\
0\end{array}$ & $\begin{array}{l}570 \\
2.7 \\
0 \\
2\end{array}$ \\
\hline & Chloride & $<9$ & 3 \\
\hline
\end{tabular}

Hansen and Harris (1975) suggest that the sample collection rate of lysimeters should equal the pore-water drainage rate because the sample intake rate of a lysimeter could affect constituent concentrations in samples from a system that has solute concentrations that vary considerably in space. To 
determine variations in water chemistry caused by different sampling rates, two samples were collected from a lysimeter located in the Hulick Till Member. These samples were collected at $-80 \mathrm{kPa}$ (kilopascals) suction, the estimated most negative suction in the till, and at $-20 \mathrm{kPa}$. Water chemistry was similar for the two samples (table 5).

\section{Table 5.--Concentrations of selected constituents in pore water collected at -20 and -80 kilopascals $(\mathrm{kPa})$ suction}

[mg/L, milligrams per liter; $\mu \mathrm{g} / \mathrm{L}$, micrograms per liter]

\begin{tabular}{lrc}
\hline & $-20 \mathrm{kPa}$ & $-80 \mathrm{kPa}^{2}$ \\
\hline Calcium (mg/L) & 110 & 110 \\
Magnesium (mg/L) & 53 & 54 \\
Sodium $(\mathrm{mg} / \mathrm{L})$ & 50 & 49 \\
Alkalinity (mg/L as $\left.\mathrm{CaCO}_{3}\right)$ & 410 & 410 \\
Silica $(\mathrm{mg} / \mathrm{L})$ & 43 & 36 \\
Copper $(\mu g / L)$ & 20 & 20 \\
Manganese $(\mu \mathrm{g} / \mathrm{L})$ & 11 & 8 \\
Strontium $(\mu \mathrm{g} / \mathrm{L})$ & 440 & 380 \\
zinc $(\mu \mathrm{g} / \mathrm{L})$ & 160 & 110 \\
\hline
\end{tabular}

\footnotetext{
ISampled 12-07-83; vacuum lysimeter 62 (Hulick Till Member of the Glasford Formation).

${ }^{2}$ Sampled 12-08-83; vacuum lysimeter 62 (Hulick Till Member of the Glasford Formation).
}

Disturbance of flow patterns by suction-induced sampling can result in samples that represent a larger soil volume than would be represented by a sample that reached the cup by way of undisturbed flow (Warrick and Amoozegar-Fard, 1977). However, tensiometers installed within $0.5 \mathrm{~m}$ of lysimeter cups showed no effect from suction-induced sampling, indicating that lysimeter samples in this study were drawn from a soil volume somewhat less than $0.5 \mathrm{~m}^{3}$.

Changes in $\mathrm{pH}$ might occur as a result of the degassing of carbon dioxide from water collected in the lysimeter. This was investigated by installing a sample-sized lysimeter at the same depth as a full-sized lysimeter. The volume of the sample-sized lysimeter was similar to the volume of the sample collected, allowing no empty space above the sample within the lysimeter. Results from four pairs of samples collected during March 1984 indicated no differences in $\mathrm{pH}$ between samples from the two lysimeters. Although it is possible that degassing occurred as water was drawn into the lysimeters, the potential for sample change due to degassing while in the lysimeters was considered negligible. 
Lysimeters located in sand yielded insufficient amounts of water for water-chemistry analyses. To obtain sufficient sample volumes from the sand, samples were composited over a few days. Results of chemical analyses on uncomposited and composited water samples from a lysimeter located in the till (table 6) indicated no significant difference in major constituents between the two samples.

Table 6.--Concentrations of selected constituents for uncomposited and composited pore-water samples

[mg/L, milligrams per liter; $\mu \mathrm{g} / \mathrm{L}$, micrograms per liter]

\begin{tabular}{lcc}
\hline & Uncomposited & Composited \\
\hline pH (standard units) & 7.7 & 7.5 \\
Calcium (mg/L) & 130 & 130 \\
Magnesium (mg/L) & 71 & 72 \\
Sodium (mg/L) & 14 & 13 \\
Alkalinity (mg/L as $\left.\mathrm{CaCO}_{3}\right)$ & 540 & 540 \\
Sulfate (mg/L) & & 67 \\
Chloride (mg/L) & 68 & 14 \\
Silica (mg/L) & 14 & 40 \\
Copper ( $\mu \mathrm{L} / \mathrm{L})$ & 34 & 40 \\
Iron ( $\mathrm{Lg} / \mathrm{L})$ & 20 & 30 \\
Manganese ( & 10 & 39 \\
Zinc ( $\mathrm{Lg} / \mathrm{L})$ & 38 & 130 \\
\hline
\end{tabular}

Claassen (1982, p. 32) reported that sampling with nitrogen affects sample chemistry less than sampling with air. Lysimeter samples for this study were collected using nitrogen gas to force samples out of lysimeters. For a more complete discussion of the representativeness of water samples collected from the unsaturated zone by using pressure-vacuum lysimeters refer to Peters and Healy (1988).

Five lysimeters were installed in borehole 585 (figs. 6 and 12), about $30 \mathrm{~m}$ east of trench 2 , to define the water chemistry in undisturbed sediments. The lysimeters referred to as "off-site". lysimeters, were located at depths from land surface of $1.2,3.5,6.7,10.1$, and $13.1 \mathrm{~m}$ in Peoria Loess, Roxana Silt, Radnor Till Member, and Toulon Member.

Five lysimeters were installed in surficial sediments (within $3 \mathrm{~m}$ of 1 and surface) near the center of the site to define the water chemistry in disturbed sediments. Three of the lysimeters were installed at depths of 0.3 , 0.6 , and $1.4 \mathrm{~m}$ in the cap of trench 2 , and two were installed at depths of 0.5 and $0.8 \mathrm{~m}$ in the swale between trenches 2 and 3 (figs. 6 and 13). 


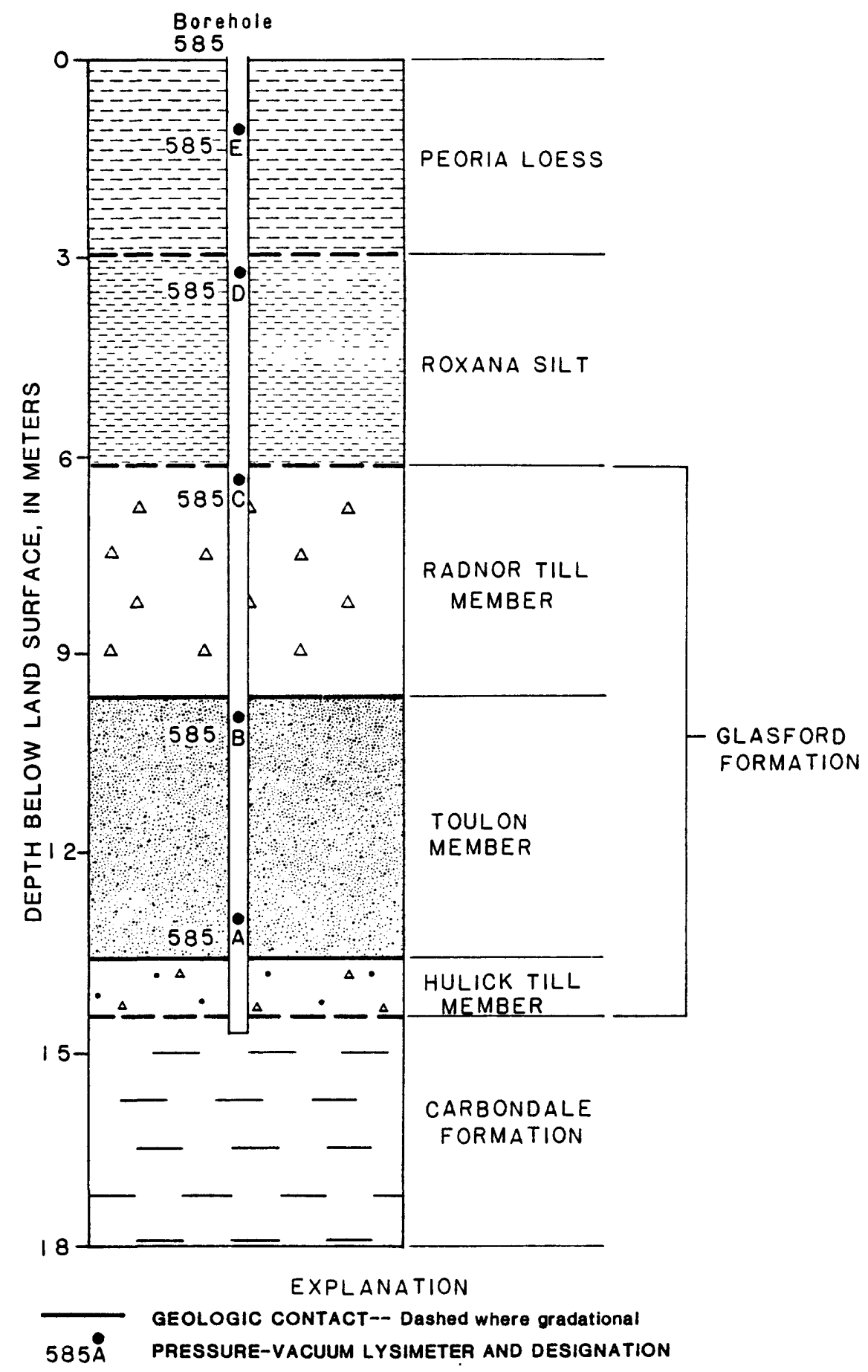

Figure 12.--Lysimeter locations off-site (borehole 585). 


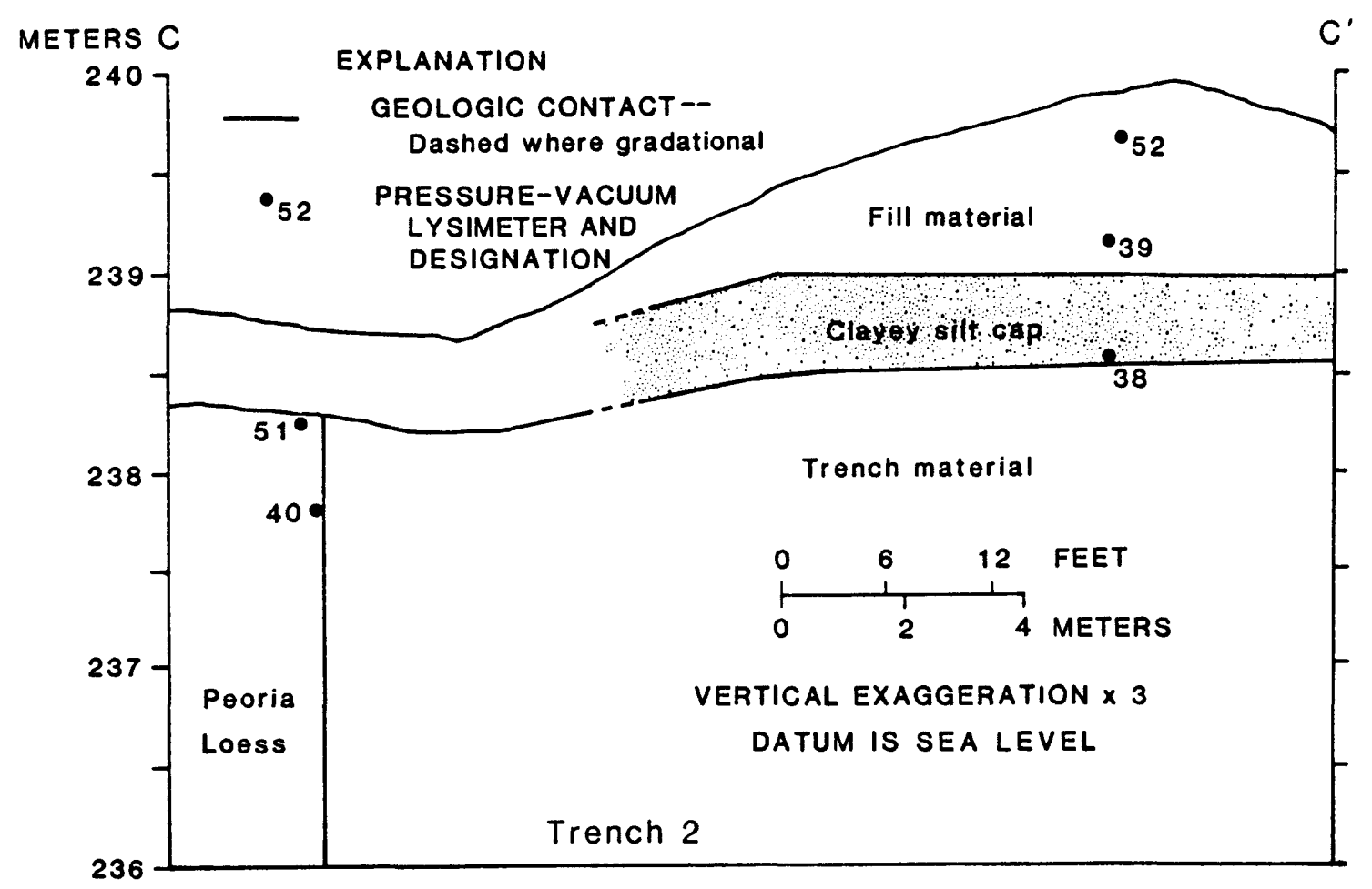

Figure 13.--Geologic section $C-C^{\prime}$ showing on-site, above-trench lysimeter locations (modified from Healy and others, 1986, fig. 8; see fig. 6 for location of line of section).

Seven lysimeters were installed in the trench caps and swales directly above the tunnel to define the water chemistry in the disturbed sediments of the unsaturated zone above the trenches. The lysimeters were installed at depths of $0.4,0.7,1.0,1.1,1.3,2.2$, and $2.3 \mathrm{~m}$ in fill material, trench material, compacted clayey silt cap, and in Peoria Loess (fig. 14). The 12 lysimeters in the disturbed sediments are referred to as "on-site, abovetrench" lysimeters.

Thirteen lysimeters were installed from inside the tunnel into the Hulick Till Member and the Toulon Member within $2 \mathrm{~m}$ of the tunnel wall. These lysimeters, referred to as "on-site, below-trench" lysimeters, were spaced at distances of about $8 \mathrm{~m}$ along most of the tunnel. Five were installed along $12 \mathrm{~m}$ of the tunnel near the sloping Toulon Member/Hulick Till Member interface (fig. 14). Below-trench lysimeters were used to define the water chemistry in the unsaturated zone beneath the waste trenches.

During the period July 1982 through June 1984, pore-water samples were collected from lysimeters every 2 weeks and analyzed for specific conductance, $\mathrm{pH}$, and tritium. Alkalinity was measured every 6 weeks, and major ions were determined quarterly. Generally, one pore-water sample from each lysimeter was analyzed for DOC. Gross alpha and beta scans were run annually on water samples from each lysimeter. During dry periods and winter, pore-water samples could not be collected from all lysimeters. 


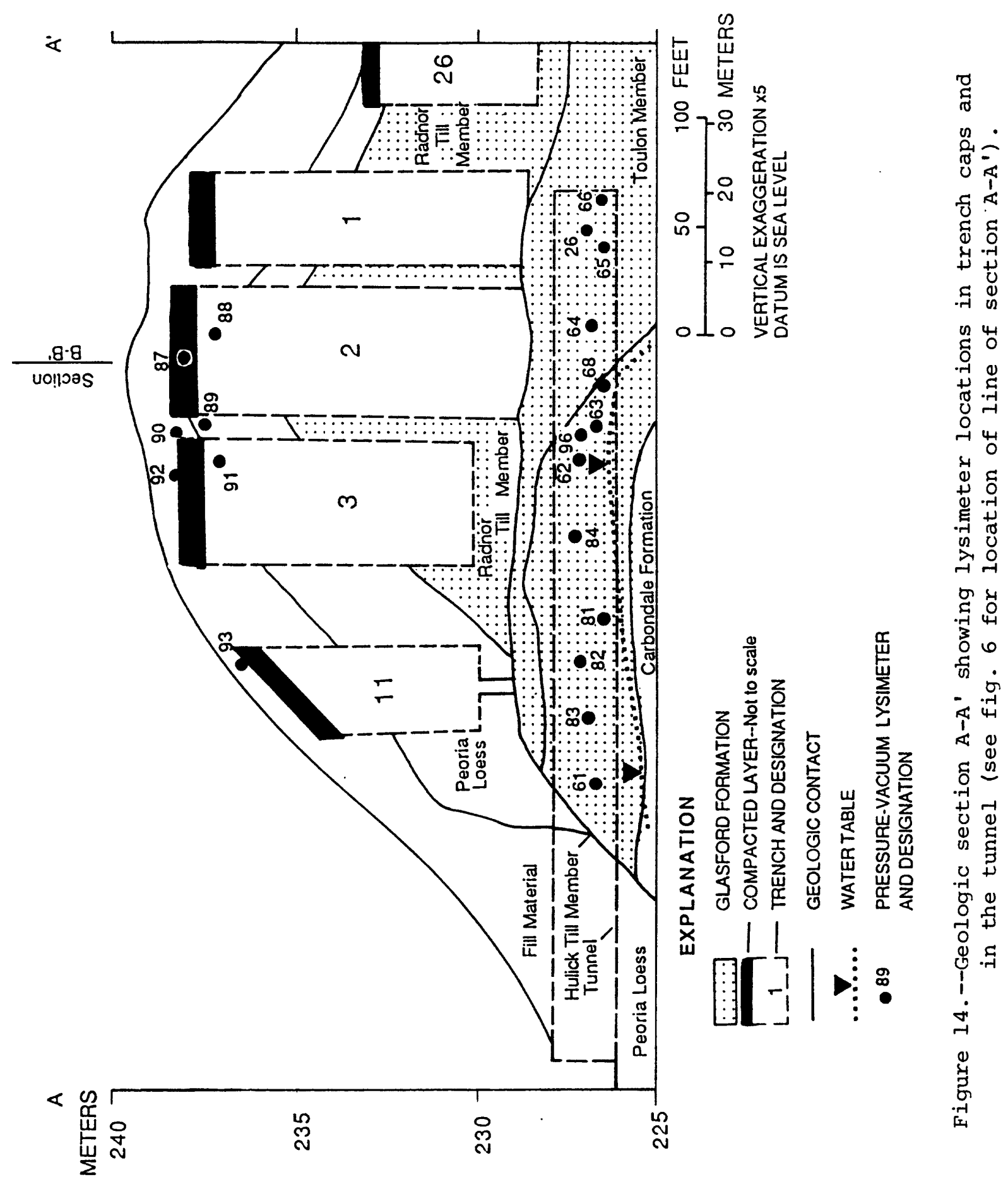




\title{
Collection of water Samples from the Saturated zone
}

\begin{abstract}
Water-chemistry data collected from seven wells by Foster and Erickson (1980) and Foster and others (1984a) were used to define the chemistry of local ground water. The wells were selected because they were near the lysimeter locations (fig. 6), their water-chemistry data were relatively complete, and the wells were screened in geologic materials similar to the materials surrounding the lysimeters. Of the seven wells, two $(502,505)$ are legally considered "off-site" wells. For the purpose of this report, wells 502, 524, and 527 also are considered off-site wells on the basis of their relative distances from the trenches.
\end{abstract}

Wells were drilled using hollow-stem augers, cased in steel, screened in stainless steel, and sealed with bentonite and portland-cement-based grout. From 1978 through 1982, water samples were collected either once or twice annually and analyzed for major ions. Tritium concentrations were measured quarterly in the seven wells in 1982 and 1983 (Foster and others, 1984a). prior to sampling, wells were purged of three casing volumes of water or bailed until dry, then allowed to recover. Water samples were collected by using a bailer or a peristaltic pump.

\section{Interpretive Technigues}

Graphs, statistics, and geochemical models were used to interpret the spatial heterogeneity of pore-water chemistry in the unsaturated zone. Graphs included trilinear diagrams, fence diagrams, and two-dimensional graphs. Trilinear diagrams (Piper, 1944) were used to show the differences in porewater chemistry between different lithologic units. Graphs were used to compare concentrations of different constituents, relate concentrations of single constituents to a specific time frame, and show relations between constituent concentrations and lithology.

Descriptive statistics, correlation coefficients, time trends, and analysis of variance were computed using P-STAT (Buhler and others, 1983) and SAS (SAS Institute, Inc., 1982) data-management and statistical-analysis computer software. The programs computed correlations between concentrations of various constituents and between concentrations and time. In all statistical analyses, analytical values less than detection limits were assumed to follow a uniform distribution between zero and the detection limit (D.A. Rickert, U.S. Geological Survey, written commun., 1985).

Analysis of variance (ANOVA) was used to determine the relative importance of factors influencing constituent concentrations. A two-by-six factorial design was used to determine simultaneously the effects of two factors on the concentrations of constituents (for example, on-site Hulick Till Member with respect to off-site Roxana Silt).

Two geochemical models were used. The first, WATEQF (Plummer and others, 1976), employs chemical speciation to calculate the saturation indices (SI) of aqueous solutions with respect to solids. The second, BALANCE (Parkhurst and others, 1982), calculates the mass transfer of constituents entering or leaving 
the aqueous phase to account for observed changes in the chemical composition of water. Mass transfer calculations (BALANCE), when combined with speciation calculations (WATEQF), are useful for defining chemical reactions that may occur in the geologic medium.

Simulations of chemical equilibria by WATEQF and BALANCE are dependent on pH. A sensitivity analysis to determine the magnitude of possible error in $\mathrm{pH}$ measurements was made by comparing calculated partial pressures of carbon dioxide $\left({ }^{\mathrm{P}} \mathrm{CO}_{2}\right)$ determined by WATEQF for lysimeters at borehole 585 to ${ }^{\mathrm{P}} \mathrm{CO}_{2}$ 's measured from similar depths from three boreholes ( $a, b$, and $c$ ) near borehole 585 (fig. 9) (Striegl, 1988). Inputs of pH to the WATEQF model from the borehole 585 lysimeters were changed until calculated $\mathrm{P}_{\mathrm{CO}_{2}}$ 's equaled measured ${ }^{\mathrm{P}_{2}} \mathrm{CO}_{2}$ 's. The $\mathrm{pH}$ change that was required to attain agreement between calculated and measured ${ }^{\mathrm{P}_{2}} \mathrm{CO}_{2}$ 's averaged $-0.2 \mathrm{pH}$ units in the Toulon Member and the Hulick Till Member, -0.7 in the Roxana Silt, -0.5 in the Radnor Till Member, and -0.9 in the Peoria Loess. The average decrease in $\mathrm{pH}$ required to match calculated and measured $\mathrm{P}_{2} \mathrm{CO}_{2} \mathrm{~s}$ was -0.46 . Possible reasons for this pH discrepancy include (1) measured ${ }^{\mathrm{P}} \mathrm{CO}_{2}$ 's from boreholes $a, b$, and $c$ may not accurately represent ${ }^{\mathrm{P}_{2}} \mathrm{CO}_{2}$ concentrations in borehole $585 ;$ (2) the probability that equilibrium conditions do not exist in major portions of the unsaturated zone; and (3) the effect of degassing of the sample as it is drawn into the lysimeter. Additionally, possible lasting effects of the leaching of ceramic cups with hydrochloric acid (Suarez, 1986) could cause the measured pH's to be lower than in situ pH's. The decreased modeled pH's caused lowered saturation indices $(S I=\log I A P / K$; where IAP $=$ the activity product of aqueous ions produced by a reaction and $K=$ the chemical-equilibrium constant for the reaction) for both calcite and dolomite, an average of -0.35 and -0.60 , respectively. However, in only a few instances were these changes large enough to cause them to fall below saturation. Saturation indices for aragonite and montmorillonite were not substantially changed.

\section{PROPERTIES OF GEOLOGIC MATERIALS}

Particle-size distributions, surface area, bulk density, and bulk porosity of geologic materials from the various lithologic units are listed in table 7. Particle-size distributions of the Hulick Till Member and Radnor Till Member of the Glasford Formation were similar, although sand content in the Hulick Till Member was slightly higher. Peoria Loess and Roxana silt had the highest percentage of silt. Surface areas were highest in the Roxana silt, the Hulick Till Member, and the Radnor Till Member, followed by the Peoria Loess. Bulk density was least in the Peoria Loess and the Roxana silt, greatest in the Radnor Till vember and Hulick Till Member, and most variable in the trench material. Porosity trends were inversely related to bulk-density trends.

Mean values of $\mathrm{pH}$, cation-exchange capacity, concentrations of calcium and magnesium, percent iron, and percent organic matter are presented in table 8. Values of $\mathrm{pH}$ for geologic materials averaged 7.5. The total range of $\mathrm{pH}$ was from 6.2 to 8.4 (Piciulo and others, 1982). The lowest $\mathrm{pH}$ values were in the Hulick Till Member, and the highest values were in the Toulon Member of the Glasford Formation. 


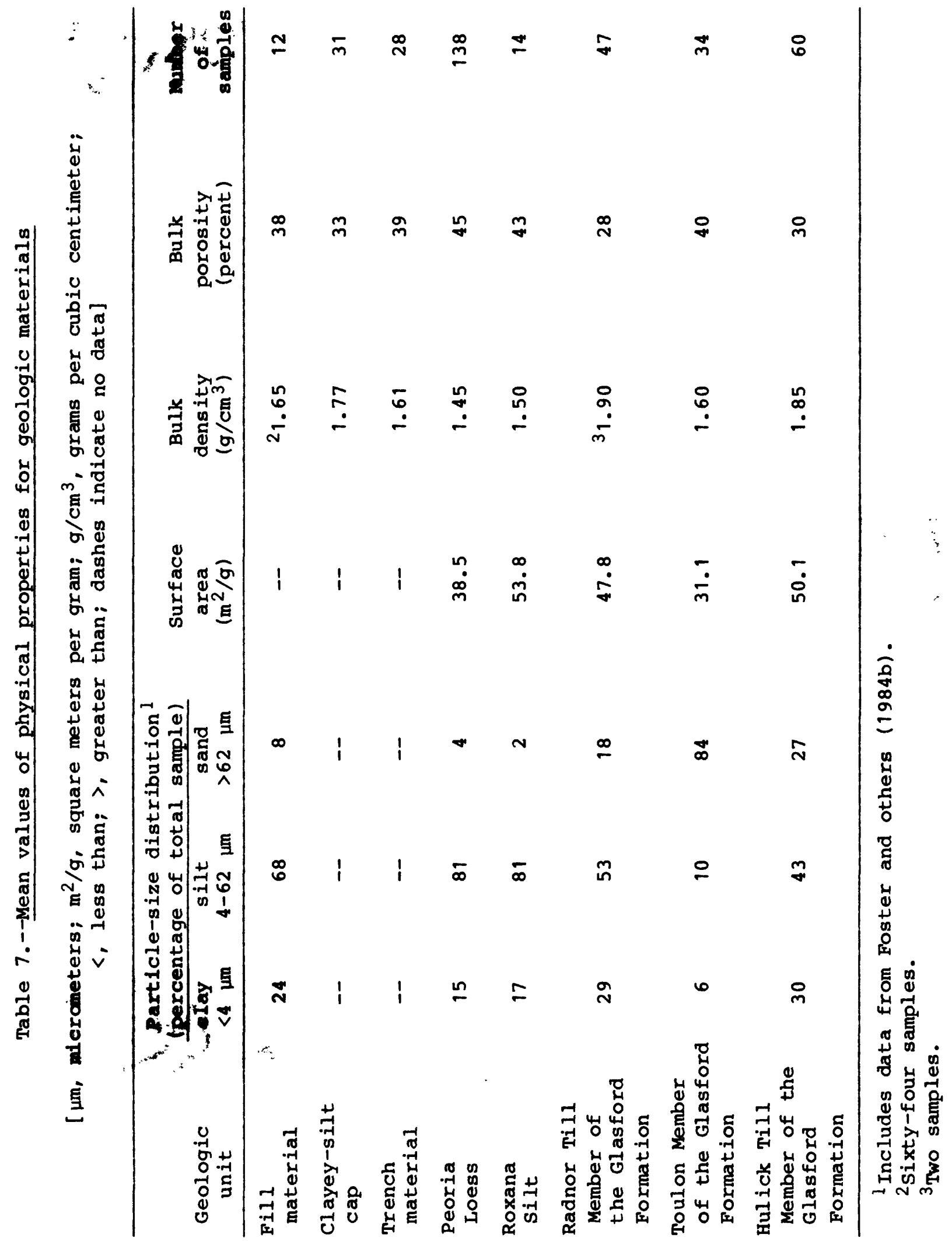


Table 8.--Mean values of chemical

[meq/100 g, milliequivalents

\begin{tabular}{lcccccc}
\hline $\begin{array}{c}\text { Geologic } \\
\text { unit }\end{array}$ & $\begin{array}{c}\text { Number } \\
\text { of } \\
\text { samples }\end{array}$ & $\begin{array}{c}\mathrm{pH}^{\mathrm{I}} \\
\text { (stand- } \\
\text { ard } \\
\text { units) }\end{array}$ & $\begin{array}{c}\text { Number } \\
\text { of } \\
\text { samples }\end{array}$ & $\begin{array}{c}\text { Cation- } \\
\text { exchange } \\
\text { capacity } \\
\text { (meq/100 g) }\end{array}$ & $\begin{array}{c}\text { Number } \\
\text { of } \\
\text { samples }\end{array}$ & $\begin{array}{c}\text { Calcium } \\
\text { (meq } / 100\end{array}$ \\
\hline $\begin{array}{l}\text { Peoria } \\
\text { Loess }\end{array}$
\end{tabular}

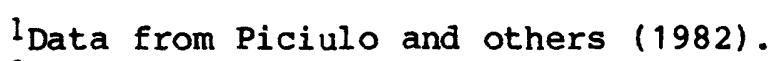

${ }^{2}$ Data from Piciulo and others (1982); Foster and others (1984b).

Mean cation-exchange capacities (CEC) for lithologic units ranged from $4.4 \mathrm{meg} / 100 \mathrm{~g}$ (milliequivalents per $100 \mathrm{grams}$ ) in the Toulon Member to 20.2 meq/100 $\mathrm{g}$ in the Radnor Till Member. Cation-exchange capacities are a significant factor when determining the exchangeability of radionuclides (Piciulo and others, 1982).

The most abundant of the exchangeable ions listed in table 8 were calcium, having mean bulk-sample concentrations of 17 to greater than $190 \mathrm{meg} / 100 \mathrm{~g}$; and magnesium, having mean concentrations of 3.6 to greater than $73 \mathrm{meq} / 100 \mathrm{~g}$. Concentrations of exchangeable ions in the geologic materials indicate their relative availability to pore water.

Iron content (as percentage of fine sands by weight) is an indicator of the potential of the medium for adsorbing chemical constituents (Jenne, 1977; Means and others, 1978). Also, iron-oxide precipitates may interact with electronegative clay minerals and adsorb radionuclides (Reesman and others, 1975, p. 12-5). The highest iron values were found in the Radnor Till Member, 


\begin{tabular}{|c|c|c|c|c|c|}
\hline $\begin{array}{l}\text { Number } \\
\text { of } \\
\text { s amples }\end{array}$ & $\begin{array}{c}\text { Magnesium } 1 \\
\text { (meq/100 g } \\
\text { as Mg) }\end{array}$ & $\begin{array}{l}\text { Number } \\
\text { of } \\
\text { samples }\end{array}$ & $\begin{array}{c}\text { Iron' } \\
\text { (percent } \\
\text { of fine } \\
\text { sands, } \\
\text { by weight) }\end{array}$ & $\begin{array}{l}\text { Number } \\
\text { of } \\
\text { samples }\end{array}$ & $\begin{array}{l}\text { Organic } \\
\text { matter } \\
\text { (percent } \\
\text { of total, } \\
\text { by weight) }\end{array}$ \\
\hline 130 & $>73$ & 4 & 3.2 & 4 & 2.1 \\
\hline 17 & 3.6 & 3 & 3.3 & 3 & .1 \\
\hline 51 & 22 & 5 & 8.3 & 5 & .5 \\
\hline 66 & 19 & 4 & .4 & 4 & .3 \\
\hline 43 & $>35$ & 3 & 1.4 & 3 & 1.9 \\
\hline
\end{tabular}

which is visibly mottled with oxidized iron, and the lowest values were in the Toulon Member.

Organic content of geologic materials can affect cation exchange, the sorptive capacity of the sediment-water system, and water movement in the materials (Brady, 1974, p. 150). Percent organic matter commonly varies from a trace to 15 percent (Brady, 1974, p. 154). Mean values of percent organic matter in unconsolidated deposits at the Sheffield site ranged from 0.1 to 2.1. The highest percentage of organic matter was in the Peoria Loess, where modern soil is developed.

Mineralogic properties of the lithologic units are shown in table 9. The matrix (in "Petrographic analysis"), which is the portion of sample that is unidentifiable because of small size, probably consists of clay minerals, silica, and feldspars. Aluminosilicate clays are derived from feldspars. 
Table 9.--Mean values of mineralogic

IDashes indicate

\begin{tabular}{|c|c|c|c|c|c|c|c|c|}
\hline \multirow[b]{2}{*}{$\begin{array}{l}\text { Geologic } \\
\text { unit }\end{array}$} & \multirow[b]{2}{*}{$\begin{array}{l}\text { Number } \\
\text { of } \\
\text { samples }\end{array}$} & \multicolumn{7}{|c|}{$\begin{array}{l}\text { Petrographic analysis } \\
\text { (percentage of fine sands) }\end{array}$} \\
\hline & & Matrix & Quartz & Feldspar & Marble & $\begin{array}{l}\text { Organic } \\
\text { matter }\end{array}$ & Volcanic & $\begin{array}{l}\text { Calcite } \\
\text { cement }\end{array}$ \\
\hline Fill material & 0 & -- & -- & - & -- & -- & -- & -- \\
\hline Peoria Loess & 4 & 31 & 41 & 5 & 0 & 5 & 2 & 11 \\
\hline Roxana silt & 0 & -- & -- & -- & -- & -- & -- & -- \\
\hline $\begin{array}{l}\text { Radnor Till } \\
\text { Member of } \\
\text { the Glasford } \\
\text { Formation }\end{array}$ & 4 & 32 & 33 & 6 & 0 & 8 & 8 & -- \\
\hline $\begin{array}{l}\text { Toulon Member } \\
\text { of the } \\
\text { Glasford } \\
\text { Formation }\end{array}$ & 9 & 4 & 49 & 6 & 20 & 0 & 8 & 5 \\
\hline $\begin{array}{l}\text { Hulick Till } \\
\text { Member of } \\
\text { the Glasford } \\
\text { Formation }\end{array}$ & 0 & -- & -- & - & -- & -- & -- & -- \\
\hline
\end{tabular}

l Data from Foster and others $(1984 \mathrm{~b})$.

2Data from Piciulo and others (1982); Foster and others (1984b).

The buffering capacity of geologic materials can be inferred from carbonate content. Peoria Loess had the highest bulk-carbonate content, and the Roxana Silt had the lowest. The Hulick Till Member had the highest calcite to dolomite ratios in the silt- and clay-size fractions.

Clay-sized particles accounted for 6 to 30 percent of the geologic materials (table 7 ). Minerals in the clay-sized fraction included montmorillonite, illite, and kaolinite plus chlorite. Montmorillonite, a sodium containing aluminosilicate of the smectite group, ranged from 82 percent of the clay mineral portion of the Roxana silt to only 17 percent of the clay mineral portion of the Toulon Member (table 9). Illite ranged from 62 percent of the clay minerals in the Toulon Member to 10 percent in the Roxana silt. Raolinite plus chlorite ranged from 27 percent in the Hulick Till Member to 8 percent in the Roxana silt.

Gross alpha and beta radiation did not exceed detection limits in any core samples of geologic materials. Detection limits were less than 1 count per hour for alpha activity and about 1 count per minute for beta activity. 


\begin{tabular}{|c|c|c|c|c|c|c|c|}
\hline \multirow[b]{2}{*}{ other } & \multicolumn{3}{|c|}{$\begin{array}{c}\text { Carbonate minerals }{ }^{2} \\
\text { (percentage of silt and } \\
\text { clay-size particles, } \\
\text { by weight) }\end{array}$} & \multicolumn{4}{|c|}{$\begin{array}{l}\text { Clay minerals } 1 \\
\text { (percentage of clay-size } \\
\text { particles, by weight) }\end{array}$} \\
\hline & $\begin{array}{l}\text { Number } \\
\text { of } \\
\text { s amples }\end{array}$ & Total & $\begin{array}{l}\text { Calcite/ } \\
\text { dolomite } \\
\text { ratio }\end{array}$ & $\begin{array}{l}\text { Number } \\
\text { of } \\
\text { samples }\end{array}$ & $\begin{array}{l}\text { Montmoril- } \\
\text { lonite }\end{array}$ & Illite & $\begin{array}{l}\text { Raolinite } \\
\text { and } \\
\text { chlorite }\end{array}$ \\
\hline-- & 24 & 16.0 & 0.01 & 15 & 69 & 17 & 14 \\
\hline 5 & 88 & 21.7 & .14 & 124 & 58 & 27 & 15 \\
\hline-- & 17 & 4.0 & .11 & 10 & 82 & 10 & 8 \\
\hline 13 & 44 & 10.6 & .12 & 39 & 44 & 42 & 14 \\
\hline 8 & 38 & 6.0 & .13 & 33 & 17 & 62 & 21 \\
\hline-- & 24 & 16.0 & .26 & 34 & 30 & 43 & 27 \\
\hline
\end{tabular}

Results of gamma-spectral analyses of 245 core samples obtained from above the tunnel were virtually identical to those determined for background samples. The highest potassium-40 concentrations measured were $7 \mathrm{pCi} / \mathrm{g}$ (picocuries per gram), followed by radium-226 at $1 \mathrm{pCi} / \mathrm{g}$. Trace amounts of radium-228, thorium-228, and thorium-234 also were detected. Concentrations refer to activity of the bulk sample and include the pore water.

\section{CHEMISTRY OF WATER SAMPLES}

The chemistry of water in the unsaturated zone is a function of the initial infiltrate chemistry, the pathway the water has taken between infiltration and the sampling points, and the rate of the water movement along the path. Chemical analyses of pore-water samples indicated bicarbonate (reported as $\mathrm{CaCO}_{3}$ (calcium carbonate) alkalinity), calcium, magnesium, sodium, sulfate, silica, chloride, iron, and zinc were the primary inorganic constituents. Samples also were analyzed for specific conductance, pH, DOC, gross alpha and beta radiation, and tritium. Table 14 (located at the end of the report) provides physical characteristics of the water-chemistry sampling sites. Results 
of analyses for inorganic constituents, DOC, and tritium also are shown in tables 15 through 19 (located at the end of the report). Table 14 aids interpretation of tables 15 through 19 and aids interpretation of table 20 (regarding saturated-zone water samples; located at the end of the report). The concentrations listed in tables 16 through 19 are for samples collected after an initial stabilization period following lysimeter installation. Chemical concentrations for some samples collected during the stabilization period were influenced by water used in grout and backfill slurries. Those concentrations were deleted from the data set. The stabilization period at borehole 585, a 150-mm-diameter borehole that contains five lysimeters, was about twice as long (about 0 to 4 months) as it was at 25-mm-diameter boreholes that contained only one lysimeter (about 0 to 2 months).

\section{Precipitation}

The specific conductance of precipitation ranged from less than 10 to 70 $\mu \mathrm{S} / \mathrm{cm}$ (microsiemens per centimeter at $25^{\circ} \mathrm{C}$ ) and averaged $28 \mu \mathrm{S} / \mathrm{cm}$ (table 15 ). Values for $\mathrm{pH}$ ranged from 3.8 to 7.5 . The average hydrogen-ion concentration, expressed as $\mathrm{pH}$, was 4.6. The ionic composition of precipitation was calcium $z$ inc sulfate ( $f i g .15)$. The average zinc concentration in precipitation was $1,300 \mu \mathrm{g} / \mathrm{L}$; this was higher than in pore water from the unsaturated zone (averaged $340 \mu \mathrm{g} / \mathrm{L}$ ) or in ground water (averaged $240 \mu \mathrm{g} / \mathrm{L}$ ). Elevated concentrations of zinc have previously been noted in precipitation in Illinois (D.F. Gatz, Illinois State water Survey, oral commun., 1984). The source of elevated concentrations of zinc in precipitation is not known. Gross-alpha and gross-beta radiation did not exceed detection limits in any precipitation or subsurface water samples. Tritium concentrations in precipitation were $0.2 \mathrm{nCi} / \mathrm{L}$.

\section{Unsaturated-Zone Pore Water}

\section{Undisturbed Unsaturated Zone, Borehole 585}

Water samples from five depths in borehole 585 were analyzed to evaluate conditions in an undisturbed area (table 16; mean values in table 10). values for $\mathrm{pH}$ ranged from 7.1 to 8.4 and averaged 7.5. The lowest average pH was 7.4 in the Toulon Member of the Glasford Formation, and the highest was 7.7 in the Peoria Loess and the Roxana Silt. Specific conductance ranged from 815 to $2,250 \mu \mathrm{S} / \mathrm{cm}$ and averaged $1,200 \mu \mathrm{S} / \mathrm{cm}$. Specific conductances varied most at lysimeter $585 \mathrm{D}$ in the Roxana Silt.

The ionic composition of water in the Peoria Loess was calcium sulfate, sodium bicarbonate sulfate in the Roxana Silt, and calcium magnesium bicarbonate in the Radnor Till Member of the Glasford Formation and Toulon Member (fig. 15). Alkalinity averaged $500 \mathrm{mg} / \mathrm{L}$ (milligrams per liter) as $\mathrm{CaCO}_{3}$ with a standard deviation of $100 \mathrm{mg} / \mathrm{L}$. Alkalinities are virtually equal to bicarbonate for the range of $\mathrm{pH}$ of all samples. Bicarbonate was the predominant anion in all water samples except for one sample from the Peoria Loess. About 32 percent of anion equivalent weight was bicarbonate in the Peoria Loess, and 66 percent was bicarbonate in the Toulon Member. Sulfate was the second most predominant anion and had the highest concentrations in water from the Peoria Loess and Roxana Silt. 


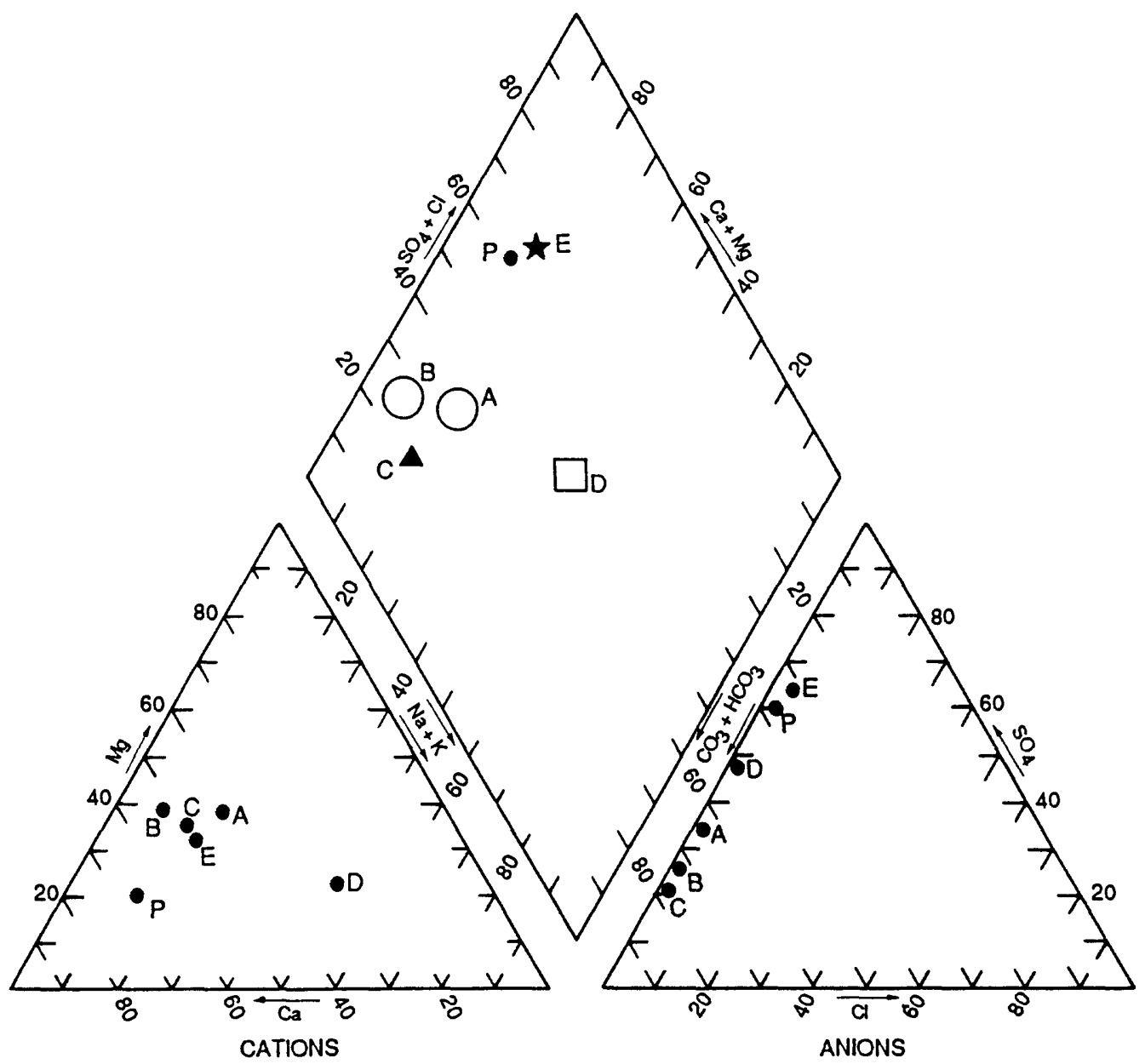

PERCENT OF TOTAL MILLIEQUIVALENTS PER LITER

\section{EXPLANATION}

BOREHOLE SITE 585 AND GEOLOGIC UNIT --Symbol size represents relative specific conductance value

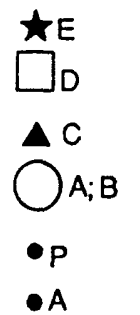

Peoria Loess

Roxana Silt

Radnor Till Member of the Glasford Formation

Toulon Member of the Glasford Formation

PRECIPITATION

SITE--Cations or anions
MEAN SPECIFIC CONDUCTANCE, IN MICROSIEMENS PER CENTIMETER AT 25 DEGREES CELSIUS

1,100

1,410

1,020

$1.160 ; 1,240$

28

Figure 15.--Ionic composition of water collected from off-site lysimeters (borehole 585) and precipitation. 


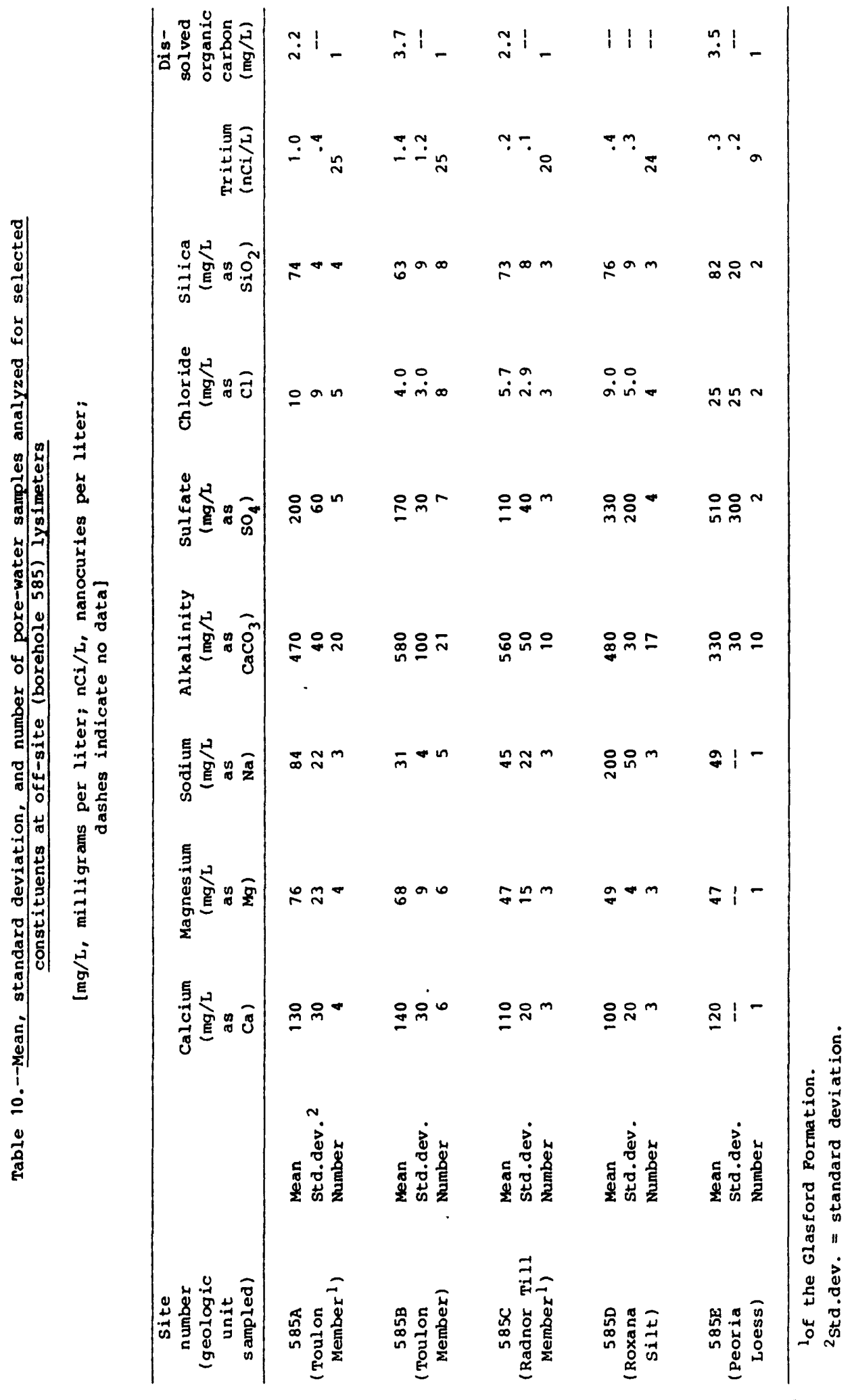


The milliequivalent ratio of calcium to magnesium varied with depth and geologic material, with the lowest ratio (1.16) in the Toulon Member, and the highest ratio (1.50) in the Roxana silt (as calculated from data in table 16). Sodium concentrations averaged $49 \mathrm{mg} / \mathrm{L}$ and had a standard deviation of $26 \mathrm{mg} / \mathrm{L}$, except in the Roxana Silt where they averaged $200 \mathrm{mg} / \mathrm{L}$ and had a standard deviation of $45 \mathrm{mg} / \mathrm{L}$.

Silica concentrations were relatively constant throughout the profile and averaged $70 \mathrm{mg} / \mathrm{L}$. Chloride concentrations averaged $8.4 \mathrm{mg} / \mathrm{L}$, with the highest concentration, $43 \mathrm{mg} / \mathrm{L}$, in the shallowest lysimeter location (Peoria Loess); the next highest concentration, $25 \mathrm{mg} / \mathrm{L}$, was in the deepest lysimeter location (Toulon Member). Zinc concentrations averaged $30 \mu \mathrm{g} / \mathrm{L}$, and concentrations increased slightly with depth. High sulfate and chloride concentrations in the Peoria Loess do not appear to be representative of typical conditions elsewhere off-site and on-site and may represent localized conditions.

Dissolved-organic-carbon concentrations ranged from 2.2 to $3.7 \mathrm{mg} / \mathrm{L}$ and averaged $2.9 \mathrm{mg} / \mathrm{L}$ at off-site lysimeters; background concentrations are considered to be approximately $3 \mathrm{mg} / \mathrm{L}$. Tritium was the only radionuclide detected. Concentrations of tritium ranged from 0.2 to $6.9 \mathrm{nCi} / \mathrm{L}$. The average off-site pore-water tritium concentration was $0.7 \mathrm{nCi} / \mathrm{L}$ and was $0.3 \mathrm{nCi} / \mathrm{L}$ in the Peoria Loess and $1.2 \mathrm{nCi} / \mathrm{L}$ in the Toulon Member. Water-quality criteria (U.S. Environmental Protection Agency, 1976) include a tentative limit of 20 $\mathrm{nCi} / \mathrm{L}$ tritium for drinking water. The U.S. Nuclear Regulatory Commission's (1975) maximum permissible concentration for tritium in effluent released to uncontrolled areas is $3,000 \mathrm{nCi} / \mathrm{L}$.

\section{Disturbed Unsaturated Zone, Above Trench}

Results of chemical analyses of water samples collected from 25 on-site lysimeters, including 12 above-trench and 13 below-trench lysimeters, are listed in tables 17 and 18. Mean concentrations of constituent are presented in table 11.

Specific conductance of pore water from on-site, above-trench lysimeters (table 17) ranged from 480 to $2,200 \mu \mathrm{S} / \mathrm{cm}$ and averaged $1,100 \mu \mathrm{S} / \mathrm{cm}$. Lowest specific conductances were for water samples from the Peoria Loess and represent recently infiltrated precipitation. The pH averaged 7.4 and ranged from 6.8 to 8.7 .

The ionic composition of water in the above-trench sediments, within at least $0.3 \mathrm{~m}$ of land surface, was calcium bicarbonate; below that depth the water generally changed to calcium magnesium bicarbonate. Alkalinity values averaged $460 \mathrm{mg} / \mathrm{L}$ as $\mathrm{CaCO}_{3}$; the minimum was $270 \mathrm{mg} / \mathrm{L}$ and the maximum was 760 $\mathrm{mg} / \mathrm{L}$. Bicarbonate was the predominant anion in all water samples except one sample from lysimeter 39. Sulfate values were nearly as dominant as bicarbonate in lysimeters 38 and 87 (clayey silt cap, figs. 13 and 14) and 39 (fill material, fig. 13). Percent anionic composition of samples from lysimeters ranged from 93 percent bicarbonate in water from lysimeters 40 and 51 (Peoria Loess) to 53 percent sulfate in water from lysimeter 39 (fill material, fig. 16). Percent compositions remained relatively constant over time for individual lysimeters. 


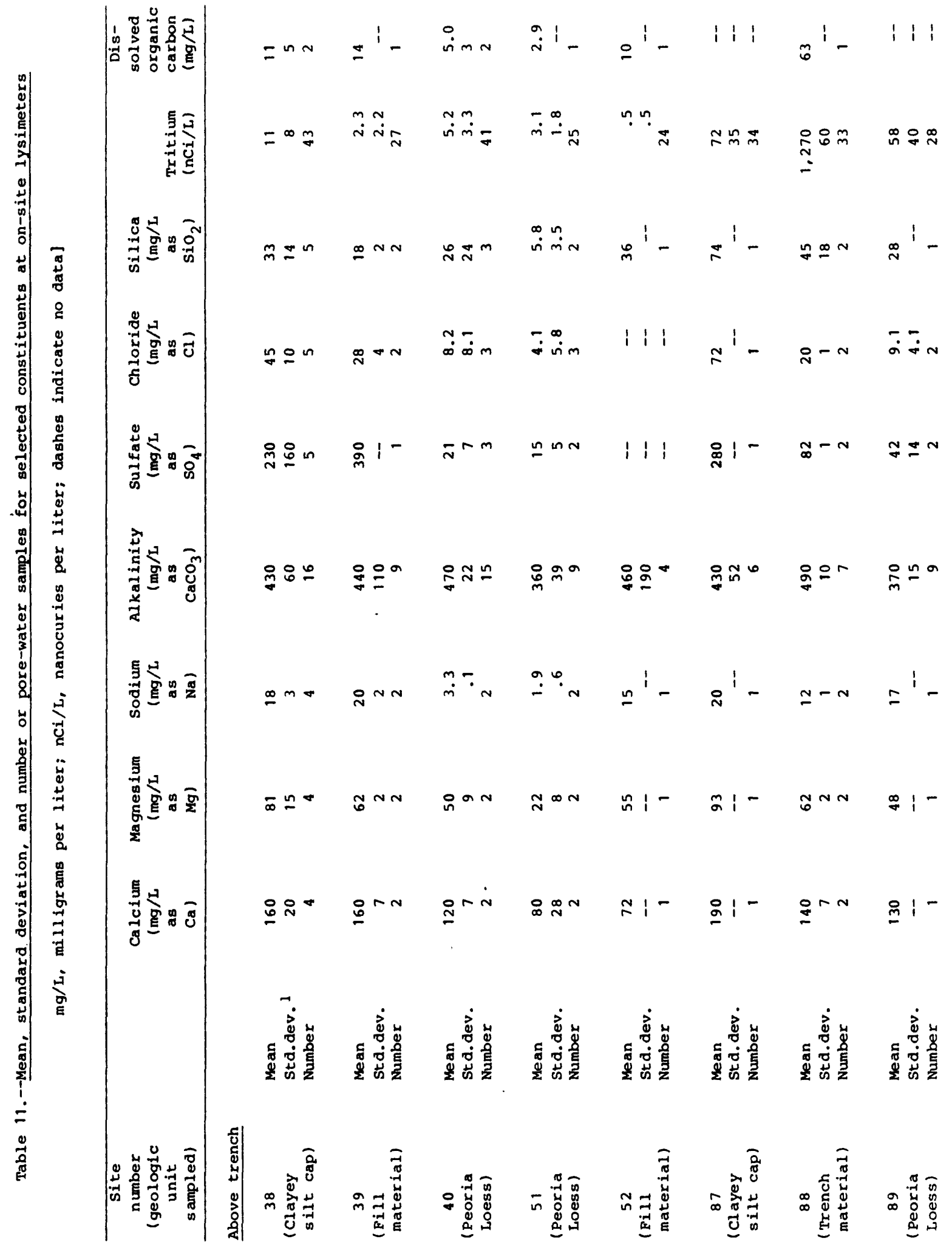




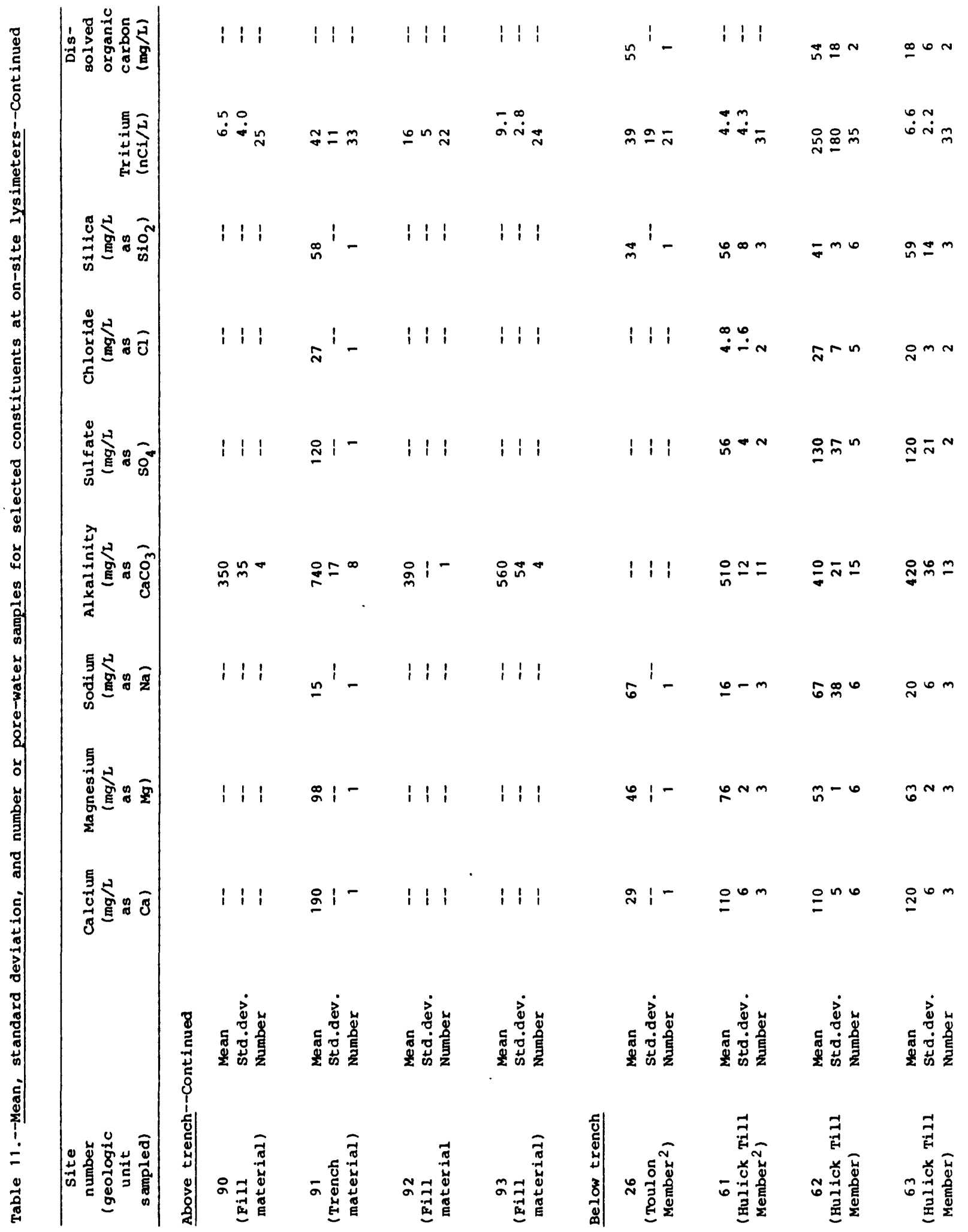




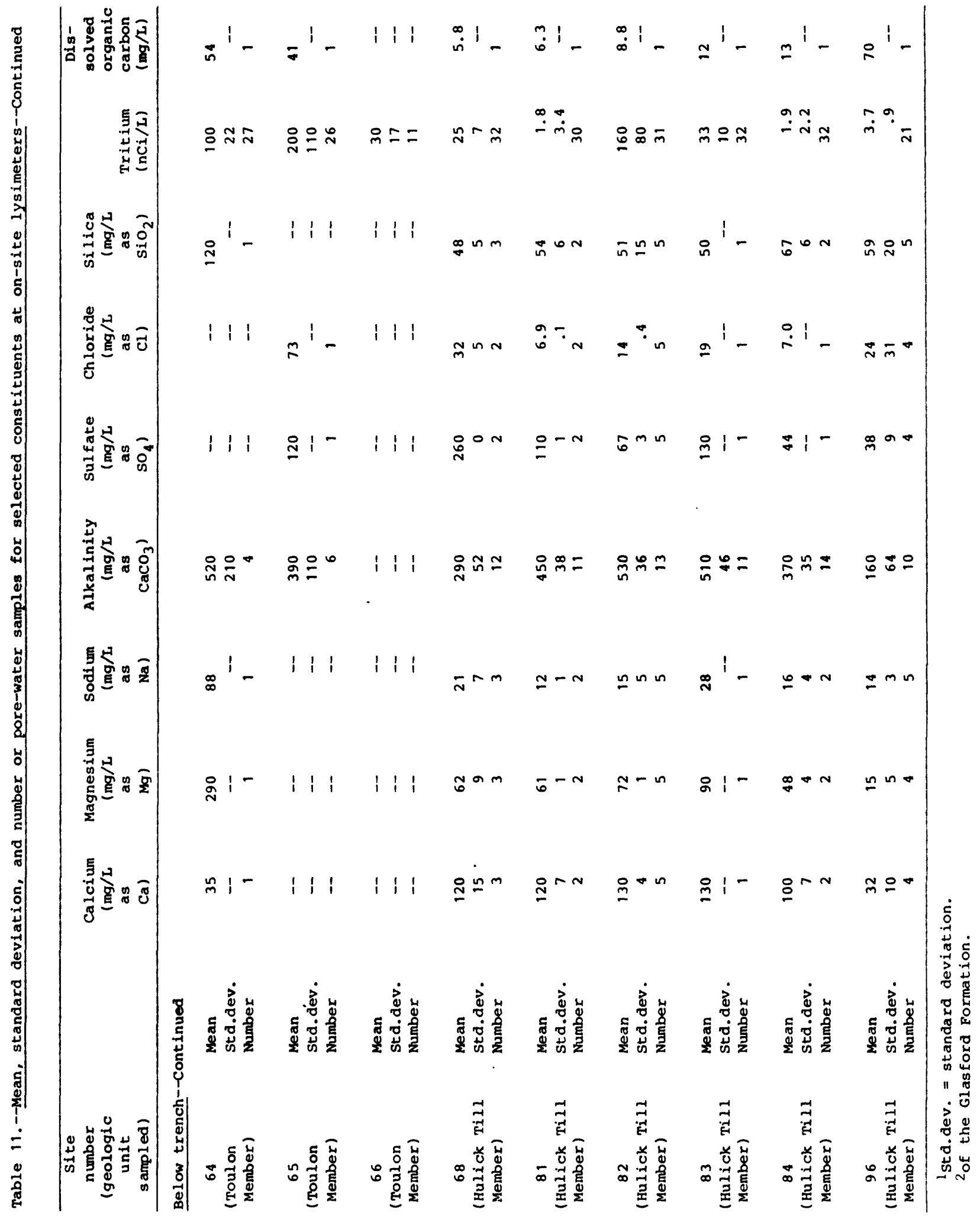




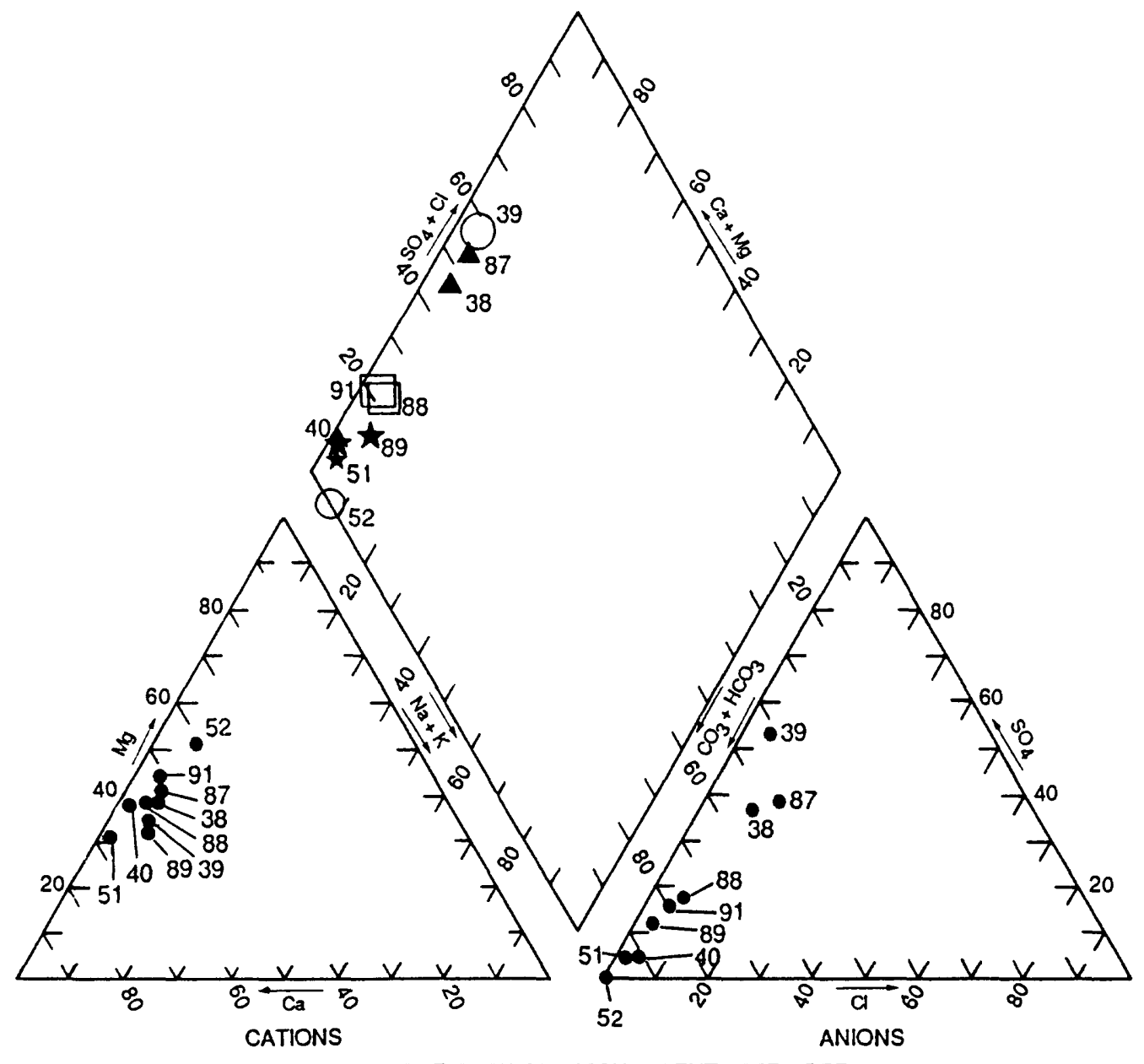

PERCENT OF TOTAL MILLIEQUIVALENTS PER LITER

\section{EXPLANATION}

SITE AND GEOLOGIC UNIT --Symbol size represents relative specific conductance value
A $87: 38$
○ 39
52
$91 ; 88$
† 89,40
$\star 51$
- 87

Clayey silt cap

Fill material

Fill material

Trench material

Peoria Loess

Peoria Loess

SITE.-Cations or anions
MEAN SPECIFIC CONDUCTANCE, IN MICROSIEMENS PER CENTIMETER AT 25 DEGREES CELSIUS

1,$310 ; 1,130$

1,330

875

$1.370 ; 1.030$

$974 ; 804$

629

Figure 16.--Ionic composition of pore water collected from on-site, above-trench lysimeters. 
Calcium was the predominant cation in all above-trench water samples except lysimeter 52 (fill material). Magnesium was the second most abundant cation in all above-trench pore-water samples except lysimeter 52, where it was most abundant. Bquivalent-weight ratios of calcium to magnesium ranged from 0.79 to 2.17 (computed from data in table 16); ratios for a $1: 1$ dolomite (equal parts calcium and magnesium) are about 1.65 (Reesman and others, 1975, p. 12-7). Sodium concentrations ranged from 1.4 to $22 \mathrm{mg} / \mathrm{L}$ and averaged 13 $\mathrm{mg} / \mathrm{L}$.

Silica concentrations ranged from 3.4 to $74 \mathrm{mg} / \mathrm{L}$ and averaged $32 \mathrm{mg} / \mathrm{L}$; water samples from lysimeter 51 (Peoria Loess) averaged only $5.8 \mathrm{mg} / \mathrm{L}$. Lower concentrations of other constituents also were reported in samples collected from lysimeter 51 .

Chloride concentrations ranged from 0.1 to $72 \mathrm{mg} / \mathrm{L}$ and averaged $25 \mathrm{mg} / \mathrm{L}$. $\mathrm{Z}$ inc concentrations averaged $140 \mu \mathrm{g} / \mathrm{L}$.

Dissolved organic carbon concentrations ranged from 2.8 to $63 \mathrm{mg} / \mathrm{L}$, with a mean of $15 \mathrm{mg} / \mathrm{L}$. The highest concentration was in water from lysimeter 88 , which is located just below the clayey silt cap in trench 2. The mean concentration for all water samples, excluding lysimeter 88 samples, was $8.5 \mathrm{mg} / \mathrm{L}$.

Tritium concentrations ranged from 0.2 to $1,380 \mathrm{nCi} / \mathrm{L}$ with a mean value of $140 \mathrm{nCi} / \mathrm{L}$ and a median value of $11 \mathrm{nCi} / \mathrm{L}$. The highest average concentration $(1,270 \mathrm{nCi} / L)$ and the highest individual concentrations were in water samples from lysimeter 88. Excluding the uncharacteristically high tritium concentrations of water samples from lysimeter 88 , tritium concentrations in water from on-site, above-trench lysimeters averaged $22 \mathrm{nci} / \mathrm{L}$. Water from lysimeter 52, located in the fill material and nearest land surface, had the lowest mean concentration $(0.5 \mathrm{nCi} / L)$.

Tritium concentrations at above-trench lysimeters varied seasonally. The highest concentrations occurred (with a slight lag time) during dry periods in the late summer and early fall when samples were less diluted by infiltrating precipitation and when evapotranspiration rates were highest (fig. 17).

Tritium concentrations in water from soil cores collected at the points of lysimeter-cup installation ranged from 0.2 to $1,230 \mathrm{nCi} / \mathrm{L}$ and averaged 68 $\mathrm{nCi} / \mathrm{L}$ in the above-trench samples (table 19); the median concentration was $2.1 \mathrm{nCi} / \mathrm{L}$. Tritium concentrations in pore water from the cores increased with depth and with proximity to trenches. The tritium concentrations in the cores generally were similar to the initial concentrations in pore water collected from lysimeters installed at the same locations.

\section{Disturbed Unsaturated Zone, Below Trench}

Specific conductances ranged from 250 to $3,500 \mu \mathrm{S} / \mathrm{cm}$ (table 18), averaged $1,060 \mu \mathrm{S} / \mathrm{cm}$, and had a standard deviation of $440 \mu \mathrm{S} / \mathrm{cm}$. The highest and most variable specific-conductance values were in water samples from the Toulon Member. The highest values in the Toulon Member (most notably at lysimeter 64) 

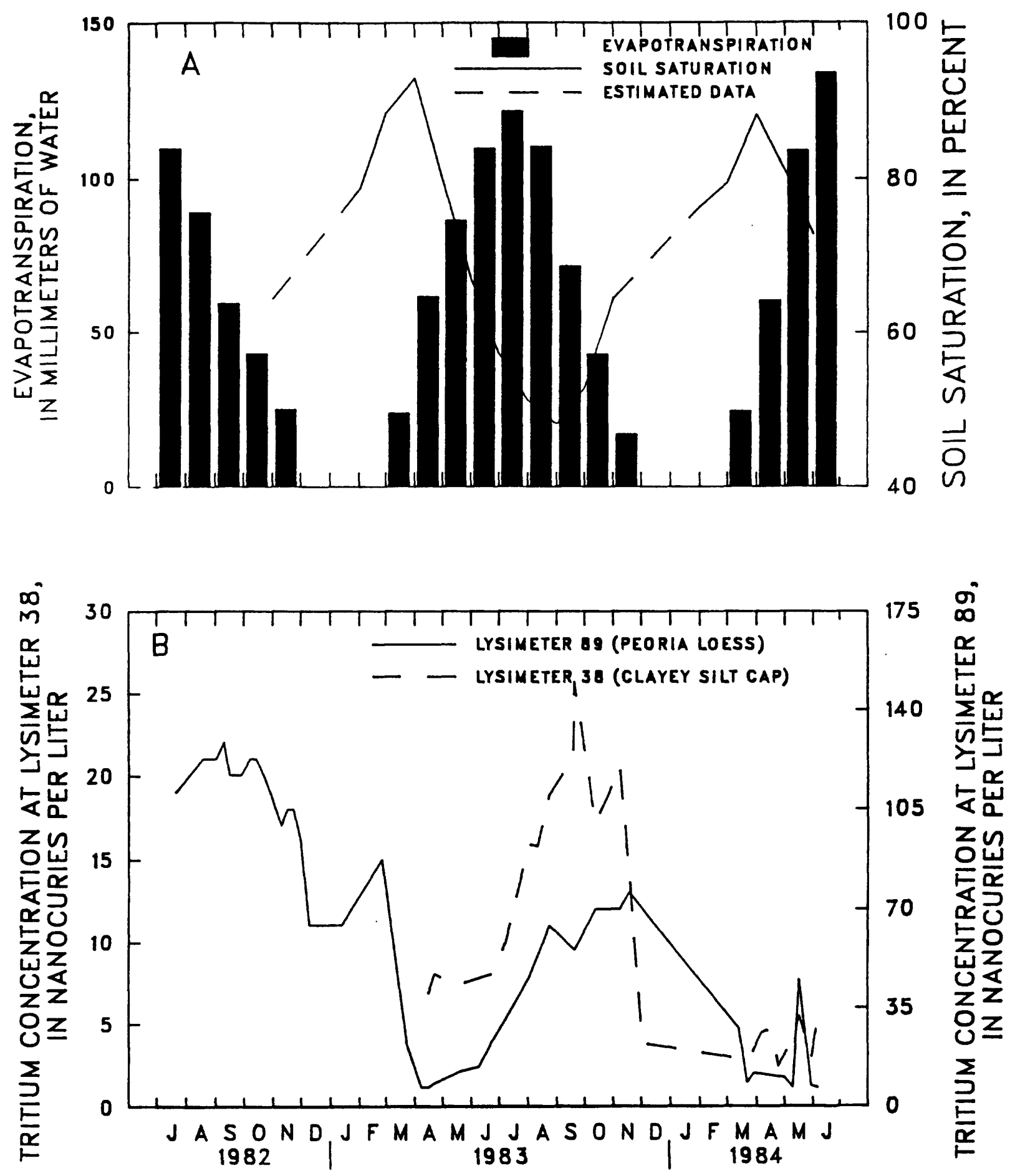

Figure 17.--Seasonal trends in evapotranspiration and soil saturation (A), and tritium concentrations at two above-trench lysimeter locations (B), July 1982 through June 1984 (modified from Mills and Healy, 1991, figs. 39 and 50). 
were commonly associated with the highest pH values, and alkalinity and DOC concentrations. Samples from lysimeter 96, located in the Hulick Till Member of the Glasford Formation near the interface with the Toulon Member, were the most dilute (figs. 7 and 18). The interface intersects the tunnel as the Hulick Till Member dips toward the northeast. Specific conductances decreased with increased distance of the lysimeters from the trenches.

The average $\mathrm{pH}$ was 7.5 , minimum $\mathrm{pH}$ was 6.9 , and maximum $\mathrm{pH}$ was 9.2. Highest pH values were in samples from lysimeters located in the Toulon Member.

The ionic composition of water generally was calcium magnesium bicarbonate. Samples from lysimeter 68, located in the Hulick Till Member near the Toulon Member/Hulick Till Member (sand/till) interface, had slightly higher sulfate (calcium magnesium sulfate) and chloride concentrations than those away from the interface and varied more chemically (fig. 18).

Alkalinity ranged from 87 to $820 \mathrm{mg} / \mathrm{L}$ and had a mean value of $410 \mathrm{mg} / \mathrm{L}$. Water samples from lysimeter 96 had the lowest mean alkalinities. The highest mean-alkalinity values were for samples from lysimeters 64,82 , and 83 . Lysimeter 64 , installed in sand near the sand/till interface below trench 2, had the highest alkalinity value. Lysimeters 82 and 83 are located below trench 11. Bicarbonate was the predominant anion in all samples except lysimeter 68. Bicarbonate and sulfate were present in nearly equivalent concentrations in samples from lysimeter 68 (Hulick Till Member).

Calcium and magnesium were the most abundant cations in water samples. Sodium concentrations ranged from 8.9 to $28 \mathrm{mg} / \mathrm{L}$ in all below-trench water samples except for samples from lysimeters 26, 62, and 64 where concentrations ranged from 32 to $140 \mathrm{mg} / \mathrm{L}$. Sodium concentrations in the Hulick Till Member near the sloping sand/till interface averaged $35 \mathrm{mg} / \mathrm{L}$, and those in the Hulick Till Member away from the interface averaged $16 \mathrm{mg} / \mathrm{L}$.

Silica concentrations in water samples ranged from 34 to $81 \mathrm{mg} / \mathrm{L}$ at all lysimeter locations except lysimeter 64 (Toulon Member); the single measurement of silica concentration at that location was $120 \mathrm{mg} / \mathrm{L}$. Chloride concentrations ranged from 3.6 to $73 \mathrm{mg} / \mathrm{L}$. The highest average concentration was from lysimeter 65 in the Toulon Member. Chloride concentrations averaged $26 \mathrm{mg} / \mathrm{L}$ in water samples from lysimeters near the sand/till interface compared to $10.9 \mathrm{mg} / \mathrm{L}$ in samples collected away from the interface. Zinc concentrations ranged from 12 to $9,700 \mu \mathrm{g} / \mathrm{L}$, had an average value of $560 \mu \mathrm{g} / \mathrm{L}$, and a median value of $140 \mu \mathrm{g} / \mathrm{L}$.

Dissolved-organic-carbon concentrations ranged from 5.8 to $70 \mathrm{mg} / \mathrm{L}$ and had a mean concentration of $32 \mathrm{mg} / \mathrm{L}$. Highest concentrations were in water samples from lysimeters 62, 64, 65, and 96, near the sand/till interface. Concentrations of DOC decreased as distance from the trenches increased.

Tritium concentrations in below-trench water samples ranged from 0.2 to $450 \mathrm{nCi} / \mathrm{L}$ and had a mean value of $70 \mathrm{nCi} / \mathrm{L}$ and a median value of $28 \mathrm{nCi} / \mathrm{L}$. Average tritium concentrations near the interface $(86 \mathrm{nCi} / \mathrm{L})$ were higher than concentrations away from the interface $(60 \mathrm{nCi} / \mathrm{L})$. Pore-water tritium concentrations in samples from some below-trench lysimeters varied seasonally (fig. 19), and highest concentrations occurred in the spring (wetter) months. 


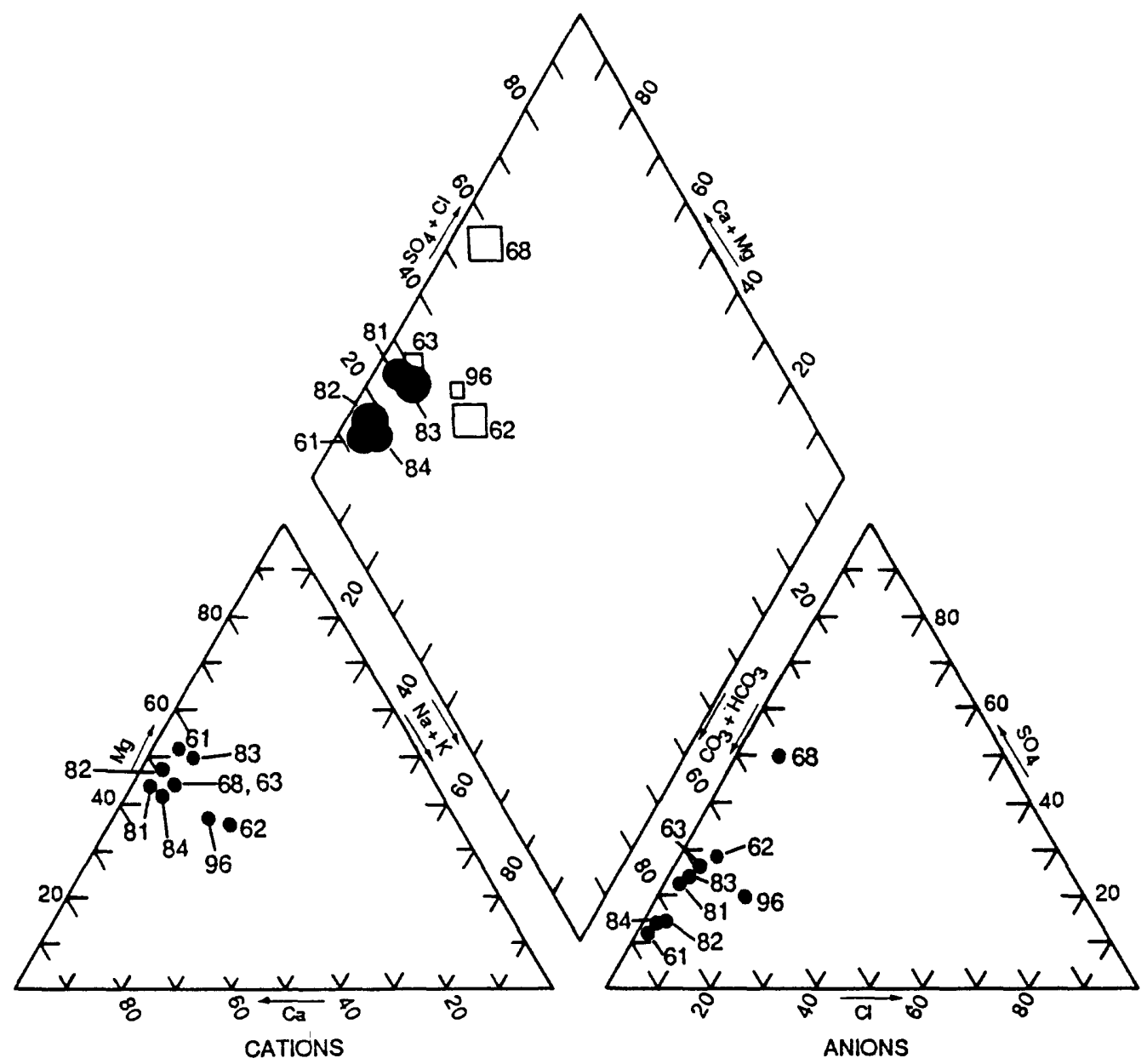

PERCENT OF TOTAL MILLIEQUIVALENTS PER LITER

\section{EXPLANATION}

SITE AND LOCATION RELATIVE TO INTERFACE WITH TOULON MEMBER OF THE GLASFORD FORMATION--Symbol size represents relative specific conductance value

$68 ; 62$

Near interface

$\square 63$

ㅁ 96

$83 ; 82$

$61 ; 81 ; 84$

- 68
Near interface

Near interface

Away from interface

Away from interface

SITE..Cations or anions

\section{MEAN SPECIFIC CONDUCTANCE, IN MICROSIEMENS PER CENTIMETER AT 25 DEGREES CELSIUS}

1,$060 ; 1,000$

978

407

1,$120 ; 1,030$

$954 ; 938 ; 826$

Figure 18.--Ionic composition of pore water collected from on-site, below-trench lysimeters in the Hulick Till Member of the Glasford Formation. 


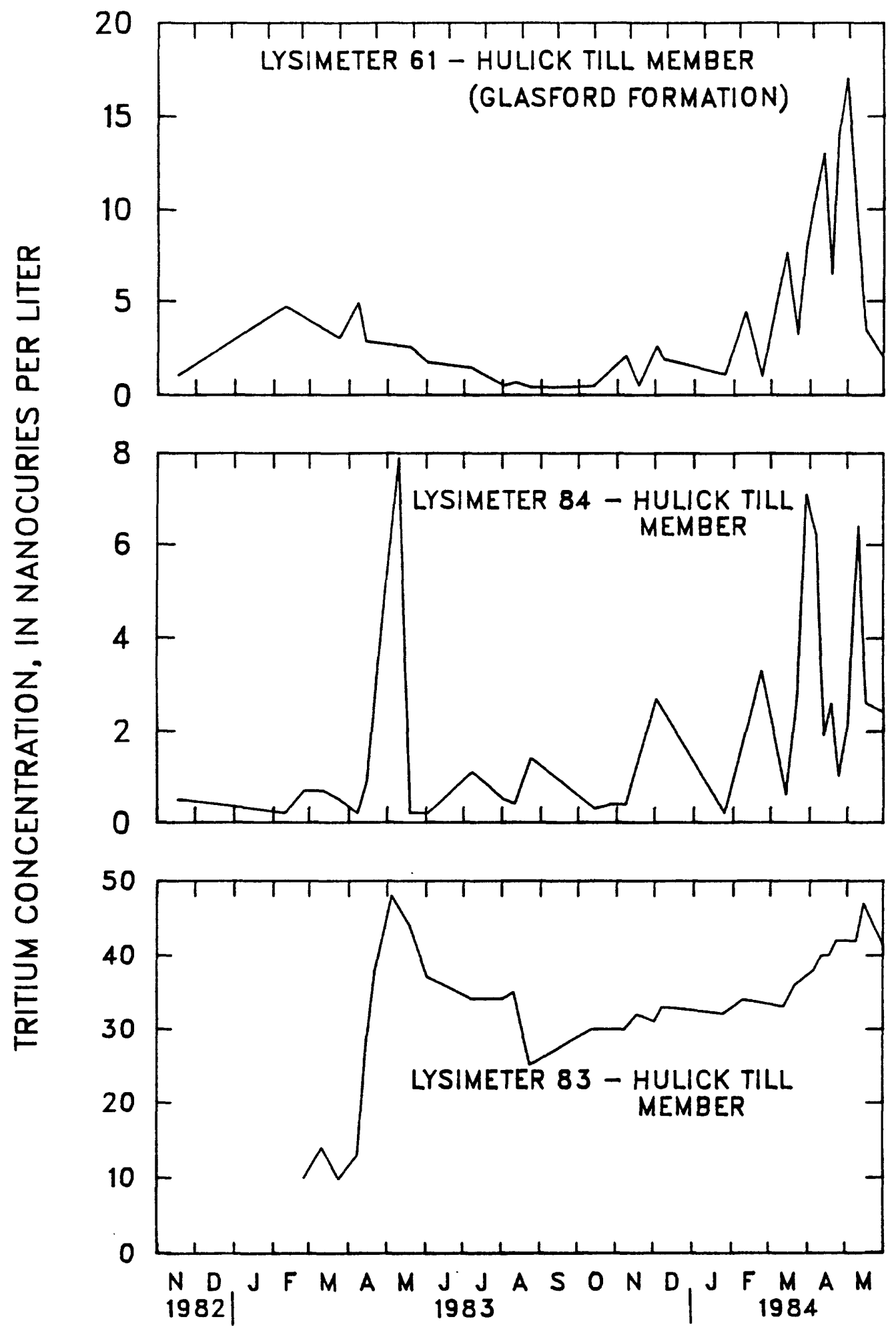

Figure 19.--Seasonal trends in tritium concentrations in pore water from three below-trench lysimeters, November 1982 through May 1984. 
High tritium concentrations in below-trench water samples in the spring may be due to freshwater infiltrating the trenches and flushing tritium from the waste materials, or due to water that had been in contact with the waste since the previous spring being flushed from the trenches. Tritium concentrations in water samples from lysimeters 62,65 , and 82 increased with time (18 months) by factors of about 4.5 to 9 ( $\mathrm{fig} .20$ ). The relatively sudden increases in tritium concentrations at lysimeters 62 and 65 appear to be related to the simultaneous occurrence of a large rainfall (124 mm) during July 29-30, 1983, and the development of several sinkholes in overlying trench caps. Tritium concentrations remained high after that time.

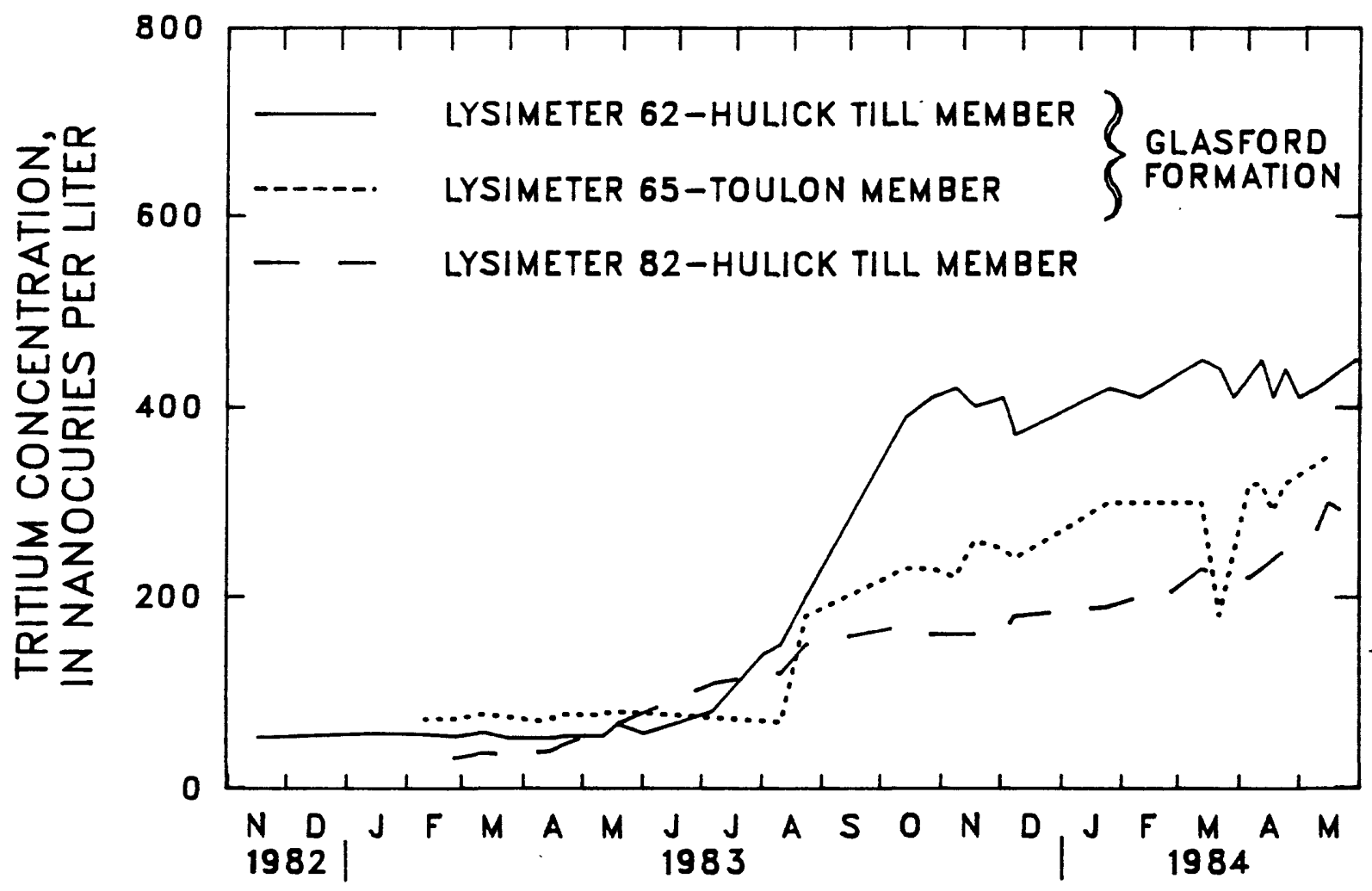

Figure 20.--Tritium concentrations in pore water from three below-trench lysimeters, November 1982 through May 1984.

Tritium and DOC concentrations in water samples from below-trench lysimeters had a moderate positive correlation (correlation coefficient of 0.55 ). This indicates an association between the sources of tritium and organic carbon (most probably the waste containers in the trenches).

Tritium concentrations in water from soil cores ranged fram 0.4 to 170 $\mathrm{nCi} / \mathrm{L}$ and averaged $44 \mathrm{nCi} / \mathrm{L}$ in the below-trench samples (table 19); the median concentration was $34 \mathrm{nCi} / \mathrm{L}$. Tritium concentrations in the below-trench cores were, for the most part, higher in sand cores than in the till cores. 
Concentrations varied most near the sloping interface between the Toulon Member and Hulick Till Member. In cores collected from the tunnel, concentrations of tritium in the tills often decreased with distance from the tunnel.

\section{Saturated-Zone Water}

Chemical analyses of water collected from the observation wells were used to define ground-water chemistry near the lysimeters (fig. 6 and table 20). Specific conductances of ground water averaged 1,140 $\mathrm{HS} / \mathrm{cm}$ and ranged from 328 to $2,130 \mu \mathrm{S} / \mathrm{cm}$. The $\mathrm{pH}$ ranged from 6.2 to 9.0 and averaged 7.0 .

The ionic composition of water was magnesium bicarbonate in all wells except well 502, where it was sodium magnesium bicarbonate. Sulfate concentrations in water samples from well 507 were higher than in samples from other wells (fig. 21).

Calcium and magnesium were the predominant cations. The mean calcium concentration was $92 \mathrm{mg} / \mathrm{L}$; the mean magnesium concentration was $85 \mathrm{mg} / \mathrm{L}$. Sodium concentrations averaged $30 \mathrm{mg} / \mathrm{L}$. In well 502 (Hulick Till Member, off-site) water samples, sodium was the predominant cation having an average concentration of $61 \mathrm{mg} / \mathrm{L}$.

Alkalinity ranged from 36 to $1,150 \mathrm{mg} / \mathrm{L}$ and averaged $490 \mathrm{mg} / \mathrm{L}$. Bicarbonate was the predominant anion in all samples. Bicarbonate equivalents composed 65 to 85 percent of the anions in all samples, with the exception of the samples from well 507 (Hulick Till Member, on-site) where bicarbonate composed 52 percent of the anions.

Silica concentrations ranged from 0.9 to $23 \mathrm{mg} / \mathrm{L}$ and averaged $12 \mathrm{mg} / \mathrm{L}$. Chloride concentrations ranged from 1.8 to $37 \mathrm{mg} / \mathrm{L}$ and averaged $8.5 \mathrm{mg} / \mathrm{L}$; lowest concentrations were from wells 502, 524, and 527, the wells that are located farthest off-site. Highest chloride concentrations in ground water were in samples from wells 505, 523, and 528, which are located adjacent to trench 11. Zinc concentrations ranged from less than 50 to $1,100 \mu \mathrm{g} / \mathrm{L}$ and averaged $240 \mu \mathrm{g} / \mathrm{L}$.

Dissolved-organic-carbon concentrations were measured in water samples collected from wells 502 and 528. Concentrations in these wells were near background levels; DOC concentrations ranged from 1.5 to $2.8 \mathrm{mg} / \mathrm{L}$ and had a mean of $2.3 \mathrm{mg} / \mathrm{L}$.

Tritium concentrations averaged $38 \mathrm{nCi} / L$, with a minimum of $0.2 \mathrm{nCi} / \mathrm{L}$ and a maximum of $170 \mathrm{nCi} / \mathrm{L}$. The lowest concentrations were in water from wells 502, 524, and 527, located farthest from trenches (off-site wells). The highest concentrations were in water from well 523 located adjacent to trench 11. Tritium concentrations in ground water were significantly different between on-site and off-site wells. On-site concentrations averaged $81 \mathrm{nCi} / \mathrm{L}$, and off-site concentrations averaged $2.9 \mathrm{nCi} / \mathrm{L}$. 


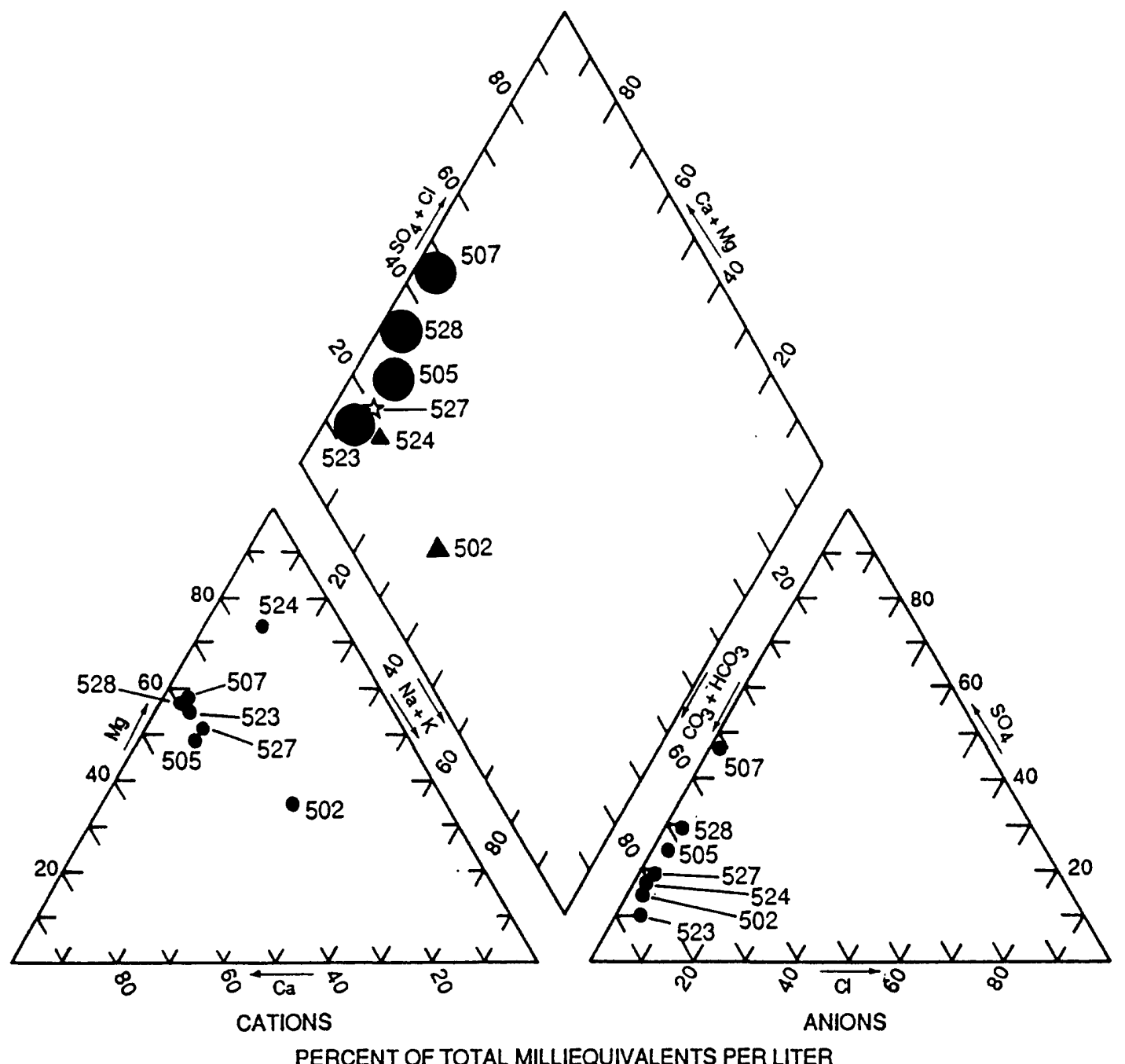

PERCENT OF TOTAL MILLIEQUIVALENTS PER LITER

\section{EXPLANATION}

SITE AND GEOLOGIC UNIT

--Symbol size represents relative

$507 ; 523$;

$505 ; 528$

次 527

$\triangle 502$

$\triangle 524$

- 507 specific conductance value

Hulick Till Member of the Glasford Formation, On-site

\section{Roxana Sitt, Off-site}

Hulick Till Member, Off-site

Hulick Till Member, Off-site

SITE--Cations or anions
MEAN SPECIFIC CONDUCTANCE, IN MICROSIEMENS PER CENTIMETER AT 25 DEGREES CELSIUS

1,$630 ; 1,480 ; 1,350 ; 1,250$

946

828

414

Figure 21.--Ionic composition of water collected from the saturated zone. 
EFFECTS OF RADIOACTIVE-WASTE DISPOSAL ON WATER CHEMISTRY

IN THE UNSATURATED ZONE

\section{Affected Constituents}

Burial of low-level radioactive waste in the unsaturated zone has the potential to alter the chemistry of pore water that percolates to the aquifer. Excavation during waste-trench construction removes geologic material that naturally interacts with water to neutralize precipitation, provides surfaces for chemical adsorption and ion exchange, and contributes ions to solution through solution-recrystallization reactions. Replacement of those materials with low-level radioactive waste provides a source that can contribute radionuclides, metals, and various organic solvents and petrochemicals to the ground-water system. Compaction of trench-cap materials over waste materials can inhibit communication between the unsaturated zone and the atmosphere, creating localized redox conditions that can mobilize some waste types. The failure of trench caps (Gray and McGovern, 1986) can provide pathways for channelized flow of surface runoff through waste materials. The sections that follow discuss the hydrogeochemical processes that determine the occurrence of dominant ions in the unsaturated zone, apparent effects of waste disposal on those processes, and chemicals present in the pore water that have a source at the waste.

\section{Carbonate Minerals}

Reactions of water and carbon dioxide with carbonate minerals largely determine the concentrations of bicarbonate, calcium, and magnesium ions in solution. Important carbonate-dissolution reactions that occur in various units in the unsaturated zone at the Sheffield site include congruent dissolution of calcite (1) and dolomite (2), which contribute $\mathrm{HCO}_{3}^{-}(\mathrm{ag})$, $\mathrm{Ca}^{+2}(\mathrm{aq})$, and $\mathrm{Mg}^{+2}(\mathrm{ag})$ ions to solution; and incongruent dissolution of dolomite to calcite (3), which contributes a $\mathrm{Mg}^{+2}(\mathrm{aq})$ ion to solution and precipitates a $\mathrm{Ca}^{+2}$ (aq) ion to calcite.

$$
\begin{aligned}
& \mathrm{CaCO}_{3}(\mathrm{~s})+\mathrm{H}_{2} \mathrm{O}(1)+\mathrm{CO}_{2}(\mathrm{aq})=\mathrm{Ca}^{+2}(\mathrm{aq})+2 \mathrm{HCO}_{3}^{-}(\mathrm{aq}) \\
& \mathrm{CaMg}\left(\mathrm{CO}_{3}\right)_{2}(\mathrm{~s})+2 \mathrm{H}_{2} \mathrm{O}_{(1)}+2 \mathrm{CO}_{2}(\mathrm{aq})=\mathrm{Ca}^{+2}(\mathrm{aq})+\mathrm{Mg}^{+2}(\mathrm{aq})+4 \mathrm{HCO}_{3}^{-}(\mathrm{aq}) \\
& \mathrm{CaMg}\left(\mathrm{CO}_{3}\right)_{2}(\mathrm{~s})+\mathrm{Ca}^{+2}(\mathrm{aq})=\mathrm{Mg}^{+2}(\mathrm{aq})+2 \mathrm{CaCO}_{3}(\mathrm{~s})
\end{aligned}
$$

Sufficient amounts of carbonate minerals are present in the unsaturated zone for reactions 1-3 to be maintained at or near chemical equilibrium. Therefore, the mass transfer of bicarbonate, calcium, and magnesium to and from solution depends on the ${ }^{\mathrm{P}_{2}}$ in the unsaturated-zone atmosphere. At borehole 585, average ${ }^{\mathrm{P}_{\mathrm{CO}}}$ increases from about 0.035 percent by volume at the land surface to about 3.9 percent at a depth of $11 \mathrm{~m}$ (Striegl and Ruhl, 1986). The largest annual variation in $\mathrm{P}_{2}$, from about 1.2 to 5 percent, is found in 
the near-surface root zone where annual peak $\mathrm{P}_{\mathrm{CO}_{2}}$ coincides with peak periods of soil-microorganism and root respiration during late summer (Thorstenson and others, 1983, p. 324-325; Suarez, 1982, p. 303).

Saturation indices were determined using the geochemical model WATEQF with the equilibrium constants shown in table 12. The SI (table 13) indicated that water samples from nearly all sites were supersaturated (SI greater than zero) with calcite and dolomite. Pore water from lysimeter 96 was undersaturated for three of four samples with respect to both calcite and dolomite. Highest SI generally were found near the surface both on-site and off-site. Lowest SI were found in the trench material on-site and just below the Roxana Silt in the Radnor Till Member of the Glasford Formation off-site (table 13). Greatest variability in the SI was in the Peoria Loess on-site and in the Roxana Silt off-site. Most samples were more saturated with dolomite than with calcite (fig. 22). This could be due to incongruent dissolution of dolomite, preferential exchange of calcium for magnesium in cation-exchange reactions with clay minerals, preferential precipitation of calcite with respect to dolomite (Drever, 1982; Thorstenson and others, 1979; Henderson, 1984), or the carbonate mineralogy of the geologic materials (table 9).

Table 12.--Equilibrium constants used in calculation of saturation indices

\begin{tabular}{lcc}
\hline \multicolumn{1}{c}{$\begin{array}{c}\text { Mineral } \\
\text { specie }\end{array}$} & $\begin{array}{c}\text { Equilibrium } \\
\text { constant, } \\
\text { temperature } \\
\text { adjusted }\end{array}$ & $\begin{array}{c}\text { Equilibrium } \\
\text { constant at } \\
\text { 25 degrees } \\
\text { Celsius }\end{array}$ \\
\hline Aragonite & -2.5890 & -8.3360 \\
Calcite & -2.2970 & -8.4800 \\
Dolomite & -9.4360 & -17.0900 \\
Gypsum & -0.0280 & -4.6020 \\
Magnesite & -6.1690 & -8.2400 \\
Montmorillonite & 60.355 & -45.2600 \\
Pyrite & 11.3000 & -18.4800 \\
\hline
\end{tabular}

Calculations made using the BALANCE model indicated the possibility of calcite precipitation from supersaturated water in the fill material, the clayey silt cap, and the Toulon Member of the Glasford Formation. Microscopic examination indicated that sand grains from upper parts of the Toulon Member at borehole 585 had secondary deposits of calcite. Calcium to magnesium ratios in the pore water decreased with depth in the unit near that location.

Rates of calcite dissolution are relatively rapid, even for extremely small ratios of calcite surface area to water volume; calcite dissolution is rapid relative to dolomite dissolution (Plummer and others, 1978). At the 
Table 13.--Saturation indices for calcite and dolomite on-site and off-site

[dashes indicate not applicable]

\begin{tabular}{|c|c|c|c|c|c|c|}
\hline & \multicolumn{3}{|c|}{ Calcite } & \multicolumn{3}{|c|}{ Dolomite } \\
\hline & Mean & Number & $\begin{array}{l}\text { Standard } \\
\text { deviation }\end{array}$ & Mean & Number & $\begin{array}{l}\text { Standard } \\
\text { deviation }\end{array}$ \\
\hline \multicolumn{7}{|c|}{ On-site } \\
\hline Fill material & 0.79 & 3 & 0.57 & 0.89 & 3 & 1.02 \\
\hline Clayey silt cap & .65 & 5 & .43 & 1.33 & 5 & 1.44 \\
\hline Trench material & .40 & 3 & .17 & .77 & 3 & .81 \\
\hline Peoria Loess & .69 & 5 & .61 & 1.22 & 5 & 1.33 \\
\hline Hulick Till Member ${ }^{l}$ & .54 & 12 & .27 & 1.10 & 12 & 1.09 \\
\hline $\begin{array}{l}\text { Hulick Till Member } \\
\text { (near Toulon Member } \\
\text { Hulick Till Member } \\
\text { interface) }\end{array}$ & .53 & 14 & .41 & 1.20 & 14 & 1.11 \\
\hline \multicolumn{7}{|c|}{ off-site } \\
\hline Peoria Loess & .59 & 1 & -- & .96 & 1 & -- \\
\hline Roxana Silt & 1.04 & 3 & .83 & 1.98 & 3 & 1.90 \\
\hline Radnor Till Member ${ }^{l}$ & .47 & 3 & .05 & .72 & 3 & .53 \\
\hline $\begin{array}{l}\text { Toulon Member } \\
\text { (shallow) }\end{array}$ & .45 & 3 & .01 & .81 & 3 & .59 \\
\hline $\begin{array}{l}\text { Toulon Member } \\
\text { (deep): }\end{array}$ & .51 & 3 & .56 & 1.23 & 3 & 1.44 \\
\hline
\end{tabular}

lof the Glasford Formation. 


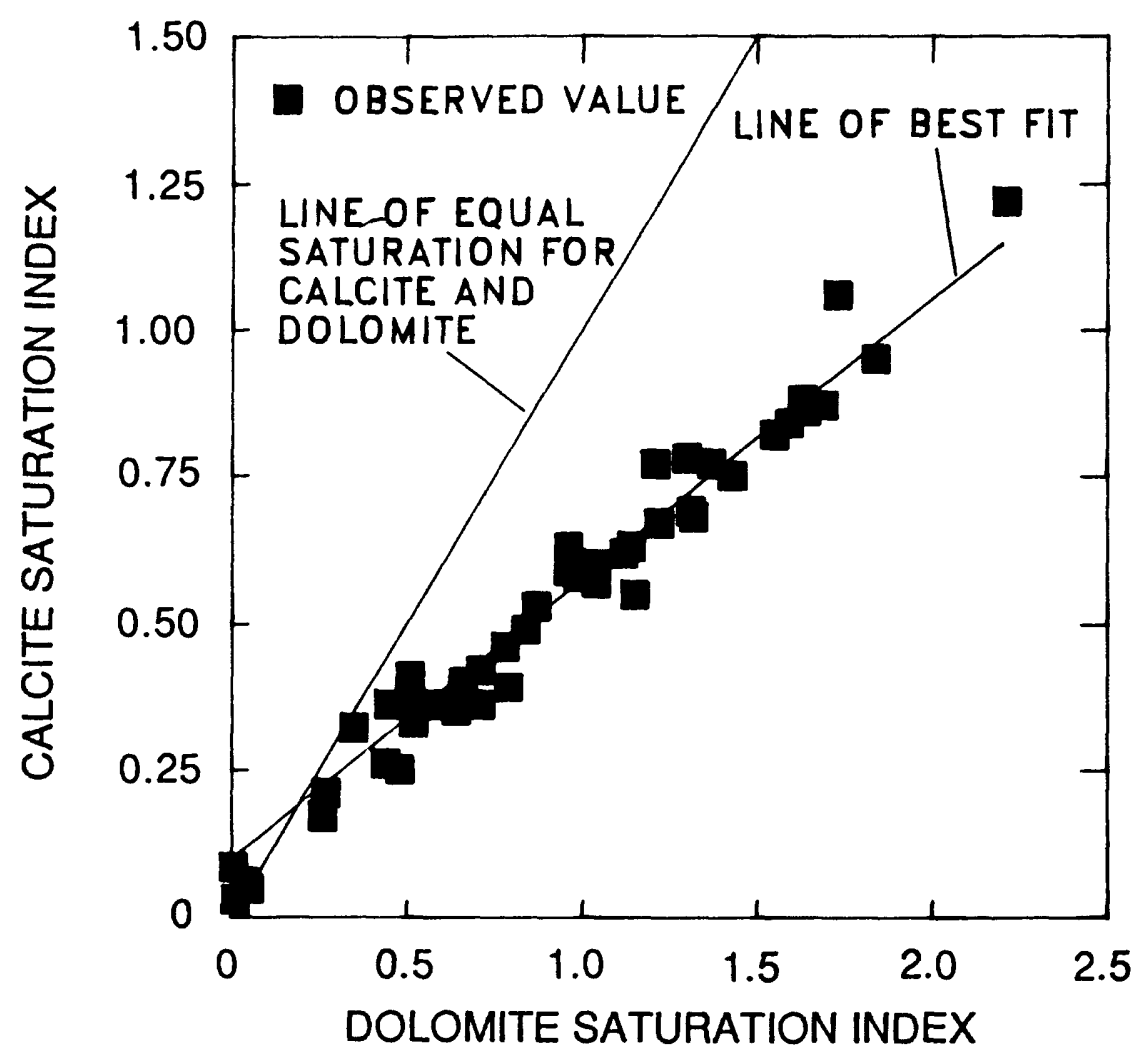

Figure 22.--Relation of dolomite saturation index to calcite saturation index.

Sheffield site, $\mathrm{Ca}^{+2}$ (aq) concentrations increased more rapidly in the first meter of depth than did $\mathrm{Mg}^{+2}(\mathrm{aq})$, even though dolomite was more abundant than calcite in those geologic materials (tables 9, 16-18, and 20).

Dissolution of carbonate minerals is more extensive at a low pH than at a high pH. In turn, the ions produced by the dissolution of carbonates buffer the pH of the water that contacts the carbonate minerals. Water that infiltrated the unsaturated zone increased from an average pH of 4.6 in precipitation to an average $\mathrm{pH}$ of 7.9 in the first $0.3 \mathrm{~m}$ from the land surface. Below that depth, the pH of water in the unsaturated zone averaged 7.5 and remained between 6.8 and 9.2 .

Pore-water $\mathrm{pH}$ was highest and most varied in the Toulon Member. High pH and large variances in $\mathrm{pH}$ can result from $\mathrm{CO}_{2}(\mathrm{aq})$ degassing fram pore water collected in lysimeters. Degassing occurs more rapidly than precipitation of carbonates and can cause increases in pH and supersaturation of water with respect to carbonate minerals (Freeze and Cherry, 1979, p. 255). It is likely that the effects of $\mathrm{CO}_{2}(\mathrm{aq})$ degassing would be most noticed for samples collected from the Toulon Member, where the average $\mathrm{P}_{\mathrm{CO}_{2}}$ is highest. Another possible reason for higher and more variable $\mathrm{pH}$ 's in the Toulon Member could be relatively rapid water movement from the trenches through the sand of the Toulon Member. 
The equilibrium chemistry of carbonate minerals also can be affected by cation-exchange processes. The Hoffmeister series, which predicts the affinity of cations to sediment surfaces in the order of $\mathrm{Ca}^{+2}>\mathrm{Mg}^{+2}>\mathrm{Na}^{+}$(Stumm and Morgan, 1981, p. 645; Brady, 1974, p. 75), favors $\mathrm{Ca}^{+2}$ and $\mathrm{Mg}^{+2}$ to adsorb to surfaces and $\mathrm{Na}^{+}$to move into solution as follows:

$$
4 \times \mathrm{Na}+\mathrm{Ca}^{2+}+\mathrm{Mg}^{2+} 4 \mathrm{Na}^{+}+\mathrm{XCa}+\mathrm{XMg} \text {. }
$$

Increased $\mathrm{Na}^{+}$concentrations coupled with decreased $\mathrm{Ca}^{+2}(\mathrm{aq})$ and $\mathrm{Mg}^{+2}(\mathrm{aq})$ concentrations ( $\mathrm{fig} .23$ ) are indicative of cation exchange (Henderson, 1984, p. 13-15). In general, high concentrations of $\mathrm{Na}^{+}(\mathrm{aq})$ were present in geologic units where the montmorillonite content of the clay-mineral fraction was high (fig. 24). As much as $250 \mathrm{mg} / \mathrm{L} \mathrm{Na}{ }^{+}$was measured in pore water collected from the Roxana Silt, where the montmorillonite content was highest ( 82 percent).

Ratios of $\mathrm{Ca}^{+2}$ (aq) to $\mathrm{Mg}^{+2}$ (aq) generally were related directly to the calcium content of the geologic materials from which pore water was collected (fig. 25). Both $\mathrm{Ca} / \mathrm{Mg}$ ratios and the content of calcium in the soil were highest in the Peoria Loess. The ratio decreases considerably from the surficial deposits to the Toulon Member both off-site and on-site (figs. 23 and 25). The pronounced decrease in the $\mathrm{Ca}^{+2}(\mathrm{aq})$ to $\mathrm{Mg}^{+2}(\mathrm{aq})$ ratio in the Toulon Member onsite is possibly induced by the presence of the tunnel. The partial pressure of $\mathrm{CO}_{2}$ in the air that is mechanically circulated through the tunnel is about two orders of magnitude less than the $\mathrm{P}_{\mathrm{CO}_{2}}$ that is naturally found in the Toulon Member. Mixture of that air into the unsaturated zone that surrounds the tunnel can cause extensive crystallization of calcite as a secondary mineral on grain surfaces. Dolomite does not readily recrystalize at the temperatures found in the unsaturated zone (Hostetler, 1964, p. 34-49); hence, $\mathrm{Mg}^{+2}(\mathrm{aq})$ concentrations remain nearly constant from the trench material to the Toulon Member. Also, more cation exchange might take place in the Roxana silt ( $S I=1.04$ for calcite and 1.98 for dolomite), which is present off-site only, resulting in decreased dissolved calcium and magnesium concentrations in the off-site Toulon Member.

\section{Sulfate}

Sulfate is the second most predominant anion found in the unsaturated zone at the Sheffield site. The possible sources of sulfate $\left(\mathrm{SO}_{4}^{-2}(\mathrm{aq})\right)$ in unsaturated-zone pore water include fragments of sulfate-rich bedrock incorporated in the till during its deposition; the oxidation of organic sulfur, which was deposited in the till after glacial-ice erosion of organic-rich bedrock; and the oxidation of the sulfide minerals pyrite and marcasite.

The availability of sulfate in the till from fragments of sulfate-rich bedrock is minimal $(0.008$ to $0.056 \mathrm{meq} / 100 \mathrm{~g}$ in dry soil). Furthermore, there is no apparent correlation between sulfate available in the various geologic units and the pore-water sulfate concentrations in those units. The oxidation of organic sulfur as a source for pore-water sulfate concentrations (Hendry and others, 1986) is possible. However, sulfate concentrations generally 

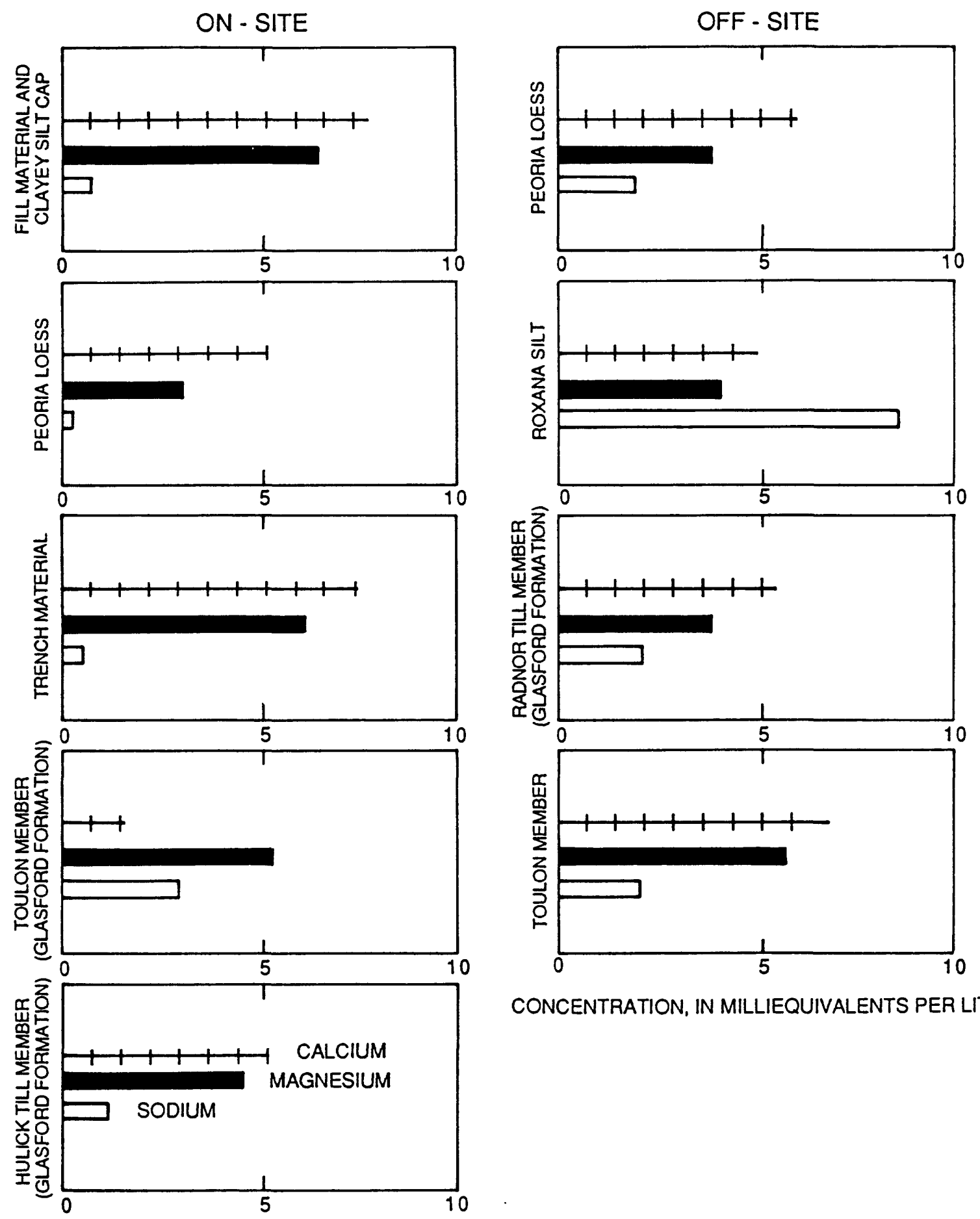

CONCENTRATION, IN MILLIEQUIVALENTS PER LITER

CONCENTRATION, IN MILLIEQUIVALENTS PER LITER

Figure 23.--Average concentrations of calcium, magnesium, and sodium in pore water from lithologic units on-site (above-trench and below-trench lysimeters) and off-site (borehole 585 lysimeters), July 1982 through May 1984. 


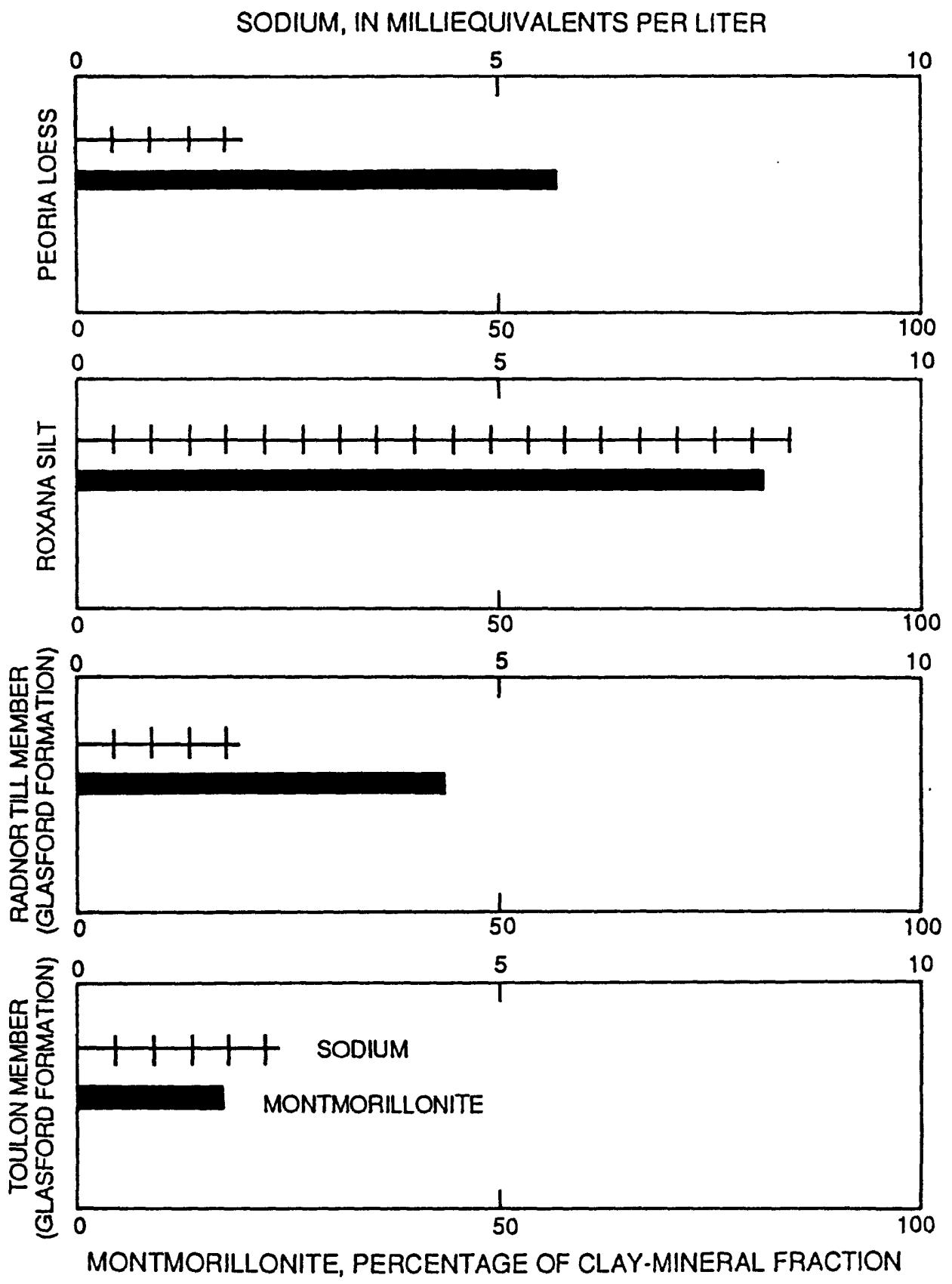

Figure 24.--Average concentration of sodium in pore water relative to average percent montmorillonite in the clay-mineral fraction of four lithologic units off-site (borehole 585 1ysimeters), October 1982 through May 1984. 
MOLAR RATIO OF CALCIUM TO MAGNESIUM

IN SOLUTION, IN LOGARITHM (BASE 10) UNITS

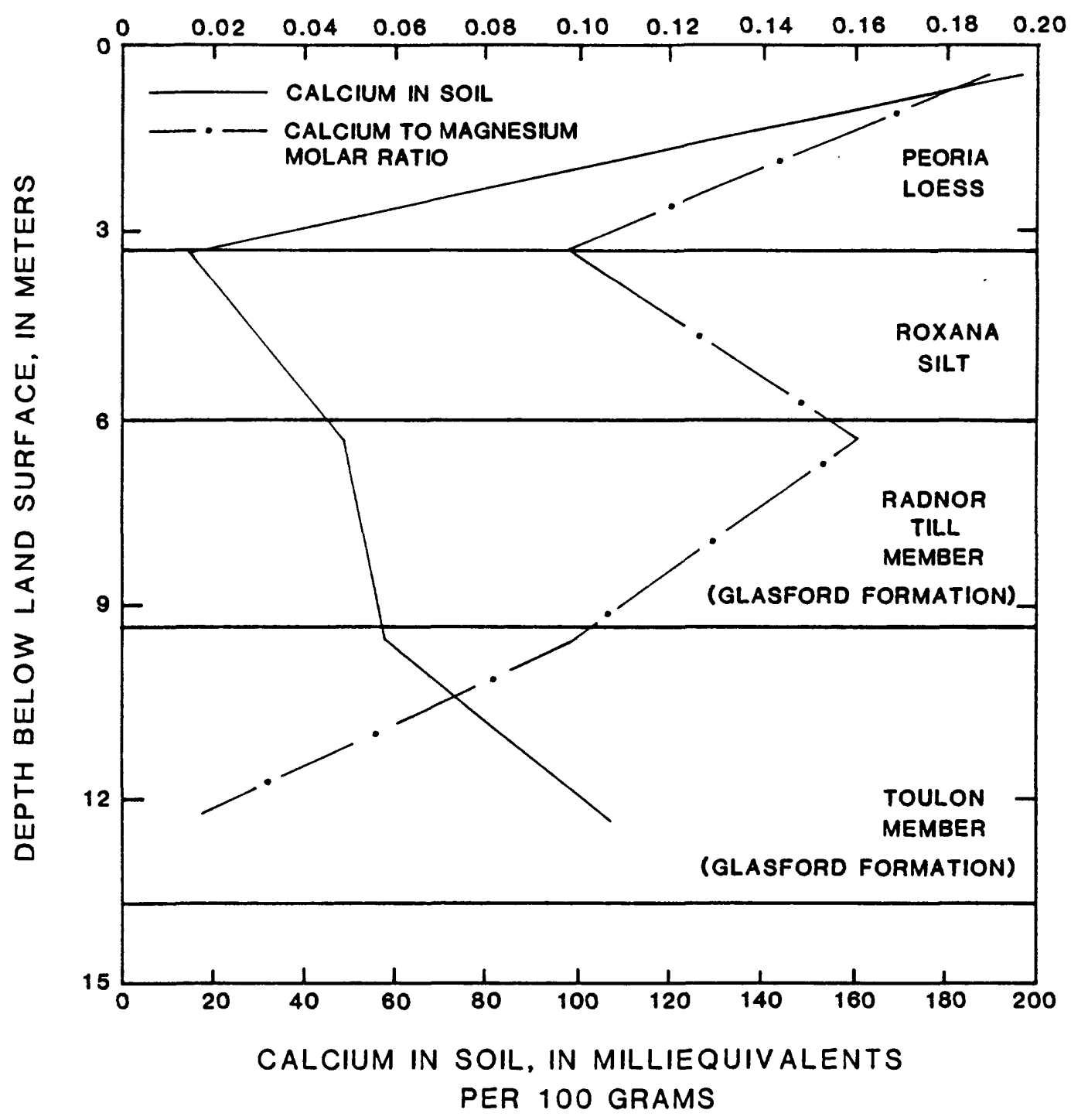

Figure 25.--Calcium content of geologic materials and molar ratios of calcium to magnesium in pore water relative to depth and geologic material offsite (borehole 585 .lysimeters). 
cannot be correlated with percent organic matter in the sediments. Thus, the apparent source of sulfate in unsaturated-zone pore water at the Sheffield site is the oxidation of sulfide minerals.

Although average concentrations of $\mathrm{SO}_{4}{ }^{-2}(\mathrm{aq})$ were higher off-site than on-site, the shape of curves that depict sulfate concentrations with respect to depth (fig. 26) are similar for both locations (with the exception of an anomalously high $\mathrm{SO}_{4}$ value in the Peoria Loess). As previously mentioned, the high sulfate concentrations in the Peoria Loess at borehole 585 might not be representative of sulfate concentrations throughout the geologic deposit; there is no obvious source for sulfate in the silt material. An anomalous source for sulfate at borehole 585 could account for the difference in on-site and off-site concentrations.

Highest sulfate concentrations were at depths of $3 \mathrm{~m}$ or less both offsite and on-site. Maximum near-surface sulfate concentrations were $720 \mathrm{mg} / \mathrm{L}$ in the Peoria Loess at borehole $585,390 \mathrm{mg} / \mathrm{L}$ in on-site fill material, and $240 \mathrm{mg} / \mathrm{L}$ in the clayey silt trench caps. The fill material and clayey silt cap on-site had the highest percentage of off-site material mixed with them. The off-site material used on-site was obtained from coal-mining overburden from the area. The decrease in sulfate concentrations below $3 \mathrm{~m}$ is possibly due to sulfate precipitation.

Sulfate concentrations in the Radnor Till, Hulick Till Member of the Glasford Formation, and the Toulon Member ranged from 30 to $280 \mathrm{mg} / \mathrm{L}$ and had a mean of $130 \mathrm{mg} / \mathrm{L}$. These sulfate concentrations were similar to those found in ground water that ranged from 13 to $710 \mathrm{mg} / \mathrm{L}$ and averaged $140 \mathrm{mg} / \mathrm{L}$.

\section{Other Inorganic Constituents}

Chloride concentrations can be indicative of the leaching of waste materials from burial sites (Johnson and Cartwright, 1980; Freeze and Cherry, 1979 , p. 436). Concentrations of chloride in lysimeter pore-water samples ranged from 0.1 to $73 \mathrm{mg} / \mathrm{L}$ and had a mean of $18 \mathrm{mg} / \mathrm{L}$. Mean chloride concentrations were higher on-site $(23 \mathrm{mg} / \mathrm{L})$ than off-site $(8.4 \mathrm{mg} / \mathrm{L})$. Highest chloride concentrations in the unsaturated zone were from the clayey silt trench caps and from below the trenches, in the Toulon Member and near the Toulon Member/Hulick Till Member interface. As previously mentioned, the high chloride concentration of $43 \mathrm{mg} / \mathrm{L}$ at borehole $585 \mathrm{E}$ does not appear to represent natural conditions elsewhere in the Peoria Loess. Highest chloride concentrations in the saturated zone were from wells located on-site.

The average silica concentration from lysimeter pore-water samples was $53 \mathrm{mg} / \mathrm{L}$. Concentrations of silica in ground water averaged $12 \mathrm{mg} / \mathrm{L}$. Silica concentrations in ground water collected from sandstones and shales are ordinarily between 2 and $60 \mathrm{mg} / \mathrm{L}$ (Hem, 1985, p. 69-73).

Lowest silica concentrations in pore water were from on-site, abovetrench sediments; mean concentrations ranged from $20 \mathrm{mg} / \mathrm{L}$ in the Peoria Loess to $40 \mathrm{mg} / \mathrm{L}$ in the clayey silt cap. Mean concentrations in geologic materials below the trenches and of $\mathrm{f}-\mathrm{site}$ ranged from $53 \mathrm{mg} / \mathrm{L}$ in the Hulick Till Member 


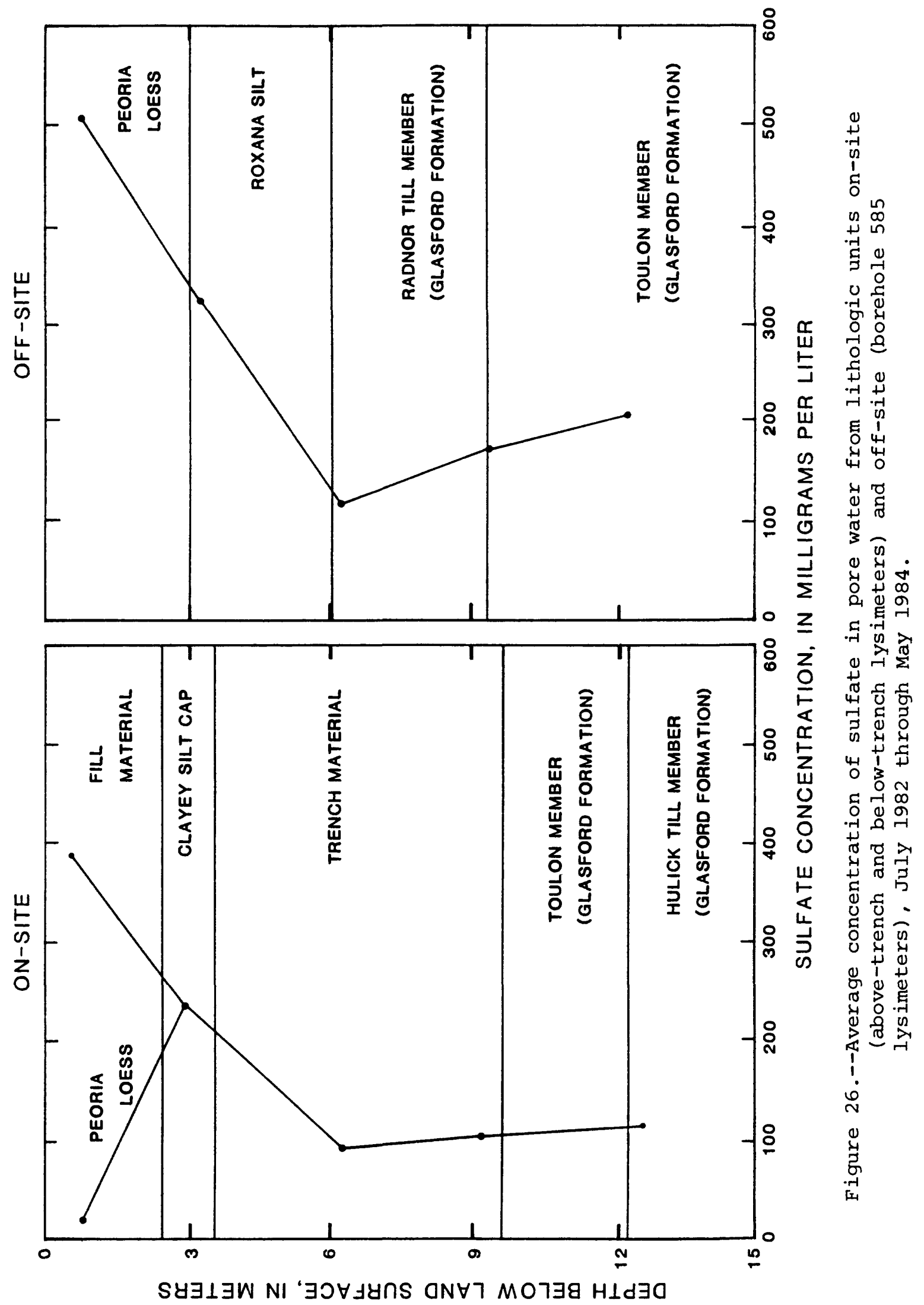


to $82 \mathrm{mg} / \mathrm{L}$ in the Peoria Loess. Likely sources of silica in the pore-water samples include the desorption of monomeric silica from the soil matrix (Wood and Signor, 1975, p. 486-488), the leaching of silica and cations from alumino silicates by water high in carbon dioxide, the dissolution of montmorillonite, and the dissolution of oxidized plant material (Reesman and others, 1975). The lower concentrations in the on-site, above-trench sediments possibly result from trench-construction activities; reworking the sediments may have accelerated the leaching process and depleted much of the silica-source materials.

The highest silica concentration, $120 \mathrm{mg} / \mathrm{L}$, occurred in the Toulon Member below trench 2 . Silica concentrations greater than $100 \mathrm{mg} / \mathrm{L}$ may indicate saturation with respect to silicate minerals present (Thorstenson and others, 1979, p. 1488; Reesman and others, 1975, p. 12-2); WATEQF results indicated supersaturation.

Comparisons between on-site, above-trench and below-trench pore-water silica concentrations show a seasonal trend (fig. 27). The high silica concentrations in late summer and early fall in samples from above-trench lysimeters indicate an increase of about 25 to $35 \mathrm{mg} / \mathrm{L}$ of silica in above-trench unsaturated-zone water. This could be due partly to the lysimeters proximity to decaying plant material. Lovering (1959) stated that grasses, such as those present at the Sheffield site, accumulate about 3.5 percent of their mass as silica. Silica in plant material is concentrated by plant decay and is transformed into a more soluble form of silica as organic matter. seasonal shifts in silica concentrations of about $20 \mathrm{mg} / \mathrm{L}$ in samples from below-trench lysimeters indicate seasonality due to something other than proximity to decaying plant tissue.

The high concentrations of zinc present in precipitation (average of $1,300 \mu \mathrm{g} / \mathrm{L})$ are not present in typical unsaturated-zone pore waters $(340 \mu \mathrm{g} / \mathrm{L})$ at the site. This is probably because at pH ranges in pore water of 6.8 to 9.2, zinc is strongly adsorbed by manganese or iron hydroxides (Stumm and Morgan, 1981, p. 625-640; Jenne, 1977). These oxides are ubiquitous in soils that are not strongly reducing. Additionally, organic matter will adsorb zinc, and $z$ inc can substitute for aluminum in montmorillonite clays. Water from lysimeters that have average zinc concentrations greater than $200 \mu \mathrm{g} / \mathrm{L}$ were either constructed, in part, with galvanized materials or were below the trenches and, hence, the contribution of the decaying metal waste containers was available. Zinc concentrations in pore-water lysimeters from off-site, where no galvanized materials were used in construction, averaged $30 \mu \mathrm{g} / \mathrm{L}$.

The oxidation of pyrite probably is the source of most of the iron in the pore water. Most of the iron released during this oxidation process likely sorbs to soil particles or precipitates as an oxide or hydroxide (B.F. Jones, U.S. Geological Survey, oral commun., 1984) and, thus, shows no correlation to high sulfate concentrations. However, mass balance calculations indicate that if the iron present in the sediments and the pore water was derived from pyrite oxidation this reaction would have been sufficient to produce the sulfate concentrations that exist in the pore water. 


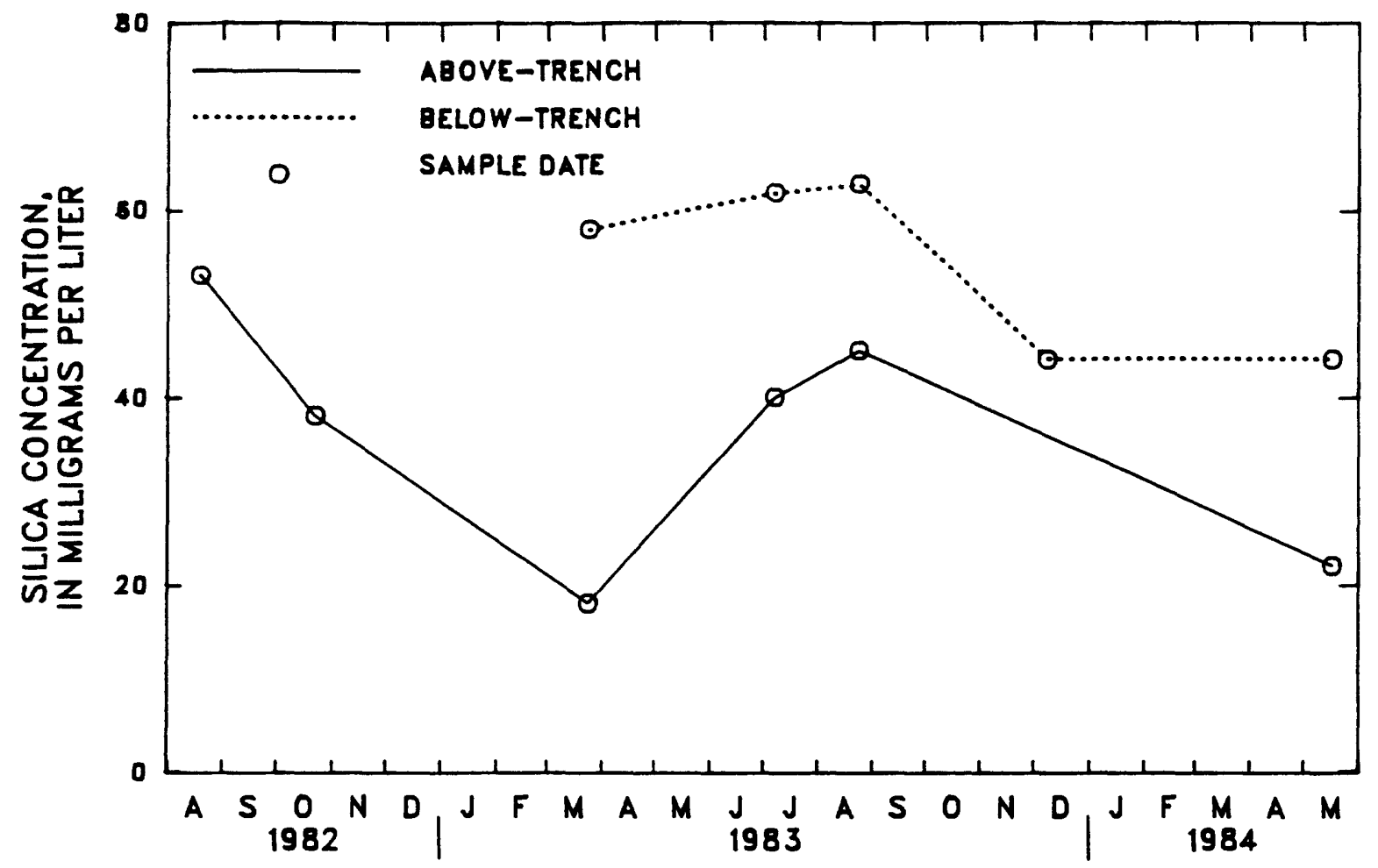

Figure 27.--Average concentration of silica in pore water from above-trench and below-trench lysimeters, August 1982 through May 1984.

Lysimeters yielding water samples with the highest iron concentrations also had high concentrations of zinc. However, not all lysimeters yielding water with high zinc concentrations had correspondingly high iron concentrations. High iron concentrations did not appear to be related to lysimeter construction materials nor to trench proximity. All the water from wells in the saturated zone had high iron concentrations due to steel well casings.

\section{Dissolved Organic Carbon}

Dissolved organic carbon that occurs naturally in the unsaturated zone is contributed by the breakdown of plant and animal matter that was recently deposited on or near the land surface and from oil shales and coal of the Carbondale Formation. Dissolved organic carbon also may originate from solvents, petroleum products, plastics, scintillation fluids, plant and animal tissues, and other organic wastes buried with the radioactive wastes.

Dissolved organic carbon concentrations were highest in water samples from below-trench lysimeters (average of $32 \mathrm{mg} / \mathrm{L}$ ) (tables 10 and 11). The highest average $D O C$ concentrations in water samples from the below-trench lysimeters were from lysimeters located in the Toulon Member $(50 \mathrm{mg} / \mathrm{L})$ and near the Toulon Member/Hulick Till Member interface $(39 \mathrm{mg} / \mathrm{L})$. Average concentrations of DOC in water near the interface were higher in July $1983(45 \mathrm{mg} / \mathrm{L})$ than in March 
$1983(28 \mathrm{mg} / \mathrm{L})$. Primary annual water movement below the trenches in 1983 occurred in mid-May (Mills and Healy, 1987). Concentrations of DOC in water samples probably were elevated in May by the flushing of DOC from the trenches due to rain-water and snowmelt percolation and remained elevated after the water had moved through.

Average DOC concentrations in water from on-site, above-trench lysimeters, excluding lysimeter 88 , were about three times as high $(8.5 \mathrm{mg} / \mathrm{L})$ as in water from of $\mathrm{f}-\mathrm{site}$ lysimeters $(2.9 \mathrm{mg} / \mathrm{L})$ and saturated-zone water $(2.3 \mathrm{mg} / \mathrm{L})$. Lysimeter 88 , which was installed just below the compacted clayey silt cap into the trench fill material, yielded water having a DoC concentration $(63 \mathrm{mg} / \mathrm{L})$ as high as concentrations below the trenches. Concentrations of DOC in water samples had a positive correlation with tritium in water samples.

\section{Tritium}

Natural concentrations of tritium in pore water at the Sheffield site are near the analytical detection limit. Pore water that has greater concentrations of tritium originates, at least partly, from the waste material. Wastederived sources of tritium include tritiated water in containers, tritium that has exchanged with pore water from solids, and biologic decomposition of tritiated organic wastes.

Tritium migration appears to be directly related to water movement in the unsaturated zone. Tritium movement in the gaseous phase has not been detected at the Sheffield site (striegl and Ruhl, 1986, p. 725). Tritium concentrations in the unsaturated zone often change in response to the seasonal movement of water. Differential rates of water movement through the various lithologic units and along interfaces between lithologic units, and the variability in the source terms cause variable rates of tritium migration and, hence, areal variability of tritium concentrations. This can be observed in concentrations of tritium in soil cores (table 19) taken at the time of tunnel construction, where slower migration rates through the till apparently resulted in lower tritium concentrations in the till than in the sand at the same altitude or distance from the trenches. The variability of tritium concentrations around the Toulon Member/Hulick Till Member interface is evidence of the importance of these interfaces as flow routes through the unsaturated zone.

Seasonal movement of water through the unsaturated zone initiates the migration of pore water stored in contact with the waste and also leaches radionuclides from the waste as water moves through the trenches. High tritium concentrations in water samples from below-trench lysimeters in spring months (fig. 19) reflect the annual wetting cycle (Mills and Healy, 1987, p. 178). High tritium concentrations in samples from some lysimeters above the trenches occur during the summer and early fall when evapotranspiration rates are high (fig. 17). This seasonal increase in tritium is caused by rewetting of the surface sediments as tritiated pore water moves upward from the trenches. The upward movement of tritiated water during high evapotranspiration periods also was indicated by tritium in the tissue of plant-cover material at the site (M.P. deVries, U.S. Geological Survey, oral commun., 1985). In addition to seasonal water movement, molecular diffusion (Freeze and Cherry, 1979, p. 103) may dictate tritium-concentration changes. 
The amount of tritium available for migration changes as the waste containers deteriorate and as the water available to cause migration increases with trench-cap deterioration. Collapse holes that develop in trench caps may allow water to move through a trench in amounts greater than usual and at atypical times. This is exemplified by the previously discussed incident in which tritium concentrations at three below-trench locations increased dramatically following the development of several collapse holes during a large precipitation event (see "Disturbed unsaturated zone, below-trench"). These collapse holes may have allowed the movement of significant quantities of water through previously isolated wastes. Water movement was not detected in connection with this precipitation event at other tunnel-area locations. Mills and Healy (1989) also discuss an incident in which an estimated 1,700 liters of water entered one trench at the Sheffield site during a single precipitation event.

Both instantaneous and continuous releases of tritium from the waste containers may occur. An instantaneous release of tritium, such as may occur when waste containers break down, may move through the unsaturated zone as a slug over several months and over a number of precipitation events. Instantaneous releases of tritium, as measured at below-trench lysimeters, show a gradual increase in tritium concentrations followed by a gradual decline. A continuous tritium release may result in continuously increasing tritium concentrations until a steady state is reached; the concentrations stabilize until the tritium source is exhausted and a gradual decline begins. These long-term fluctuations in tritium concentrations have been observed in water samples from several below-trench lysimeters. The early variability of tritium concentrations in the soil cores along the length of the tunnel has become less variable (as observed in pore-water samples).

In general, tritium concentrations increased during the 2-year study period. Tritium concentrations, however, decreased in water from some lysimeters while increasing at others. Figure 28 shows trends in tritium concentrations in pore water and ground water in the vicinity of the Sheffield site during July 1982 through May 1984; the values represent average concentrations on dates when samples were obtained from all instruments located at the specified sample sites (all "above-trench" lysimeters, for example). Most notable increases in tritium concentrations were in pore water below the trenches and in ground water on-site. The greatest tritium concentrations in ground water were in water samples from on-site wells. However, because of the complex nature of ground-water flow at the site (Foster and others, 1984), it is not always possible to relate tritium concentrations in the saturated zone to the proximity of the sampling point to the trenches. The movement of tritiated water may be short-circuited in the unsaturated zone, as lateral flow occurs along boundaries between geologic units of contrasting permeability. This phenomenon has been described at the Sheffield site by Mills and Healy (1987, p. 183) and might account for the unexpectedly rapid migration of tritium along a flow path in the southeast corner of the site (Foster and others, 1984 , p. 23). 


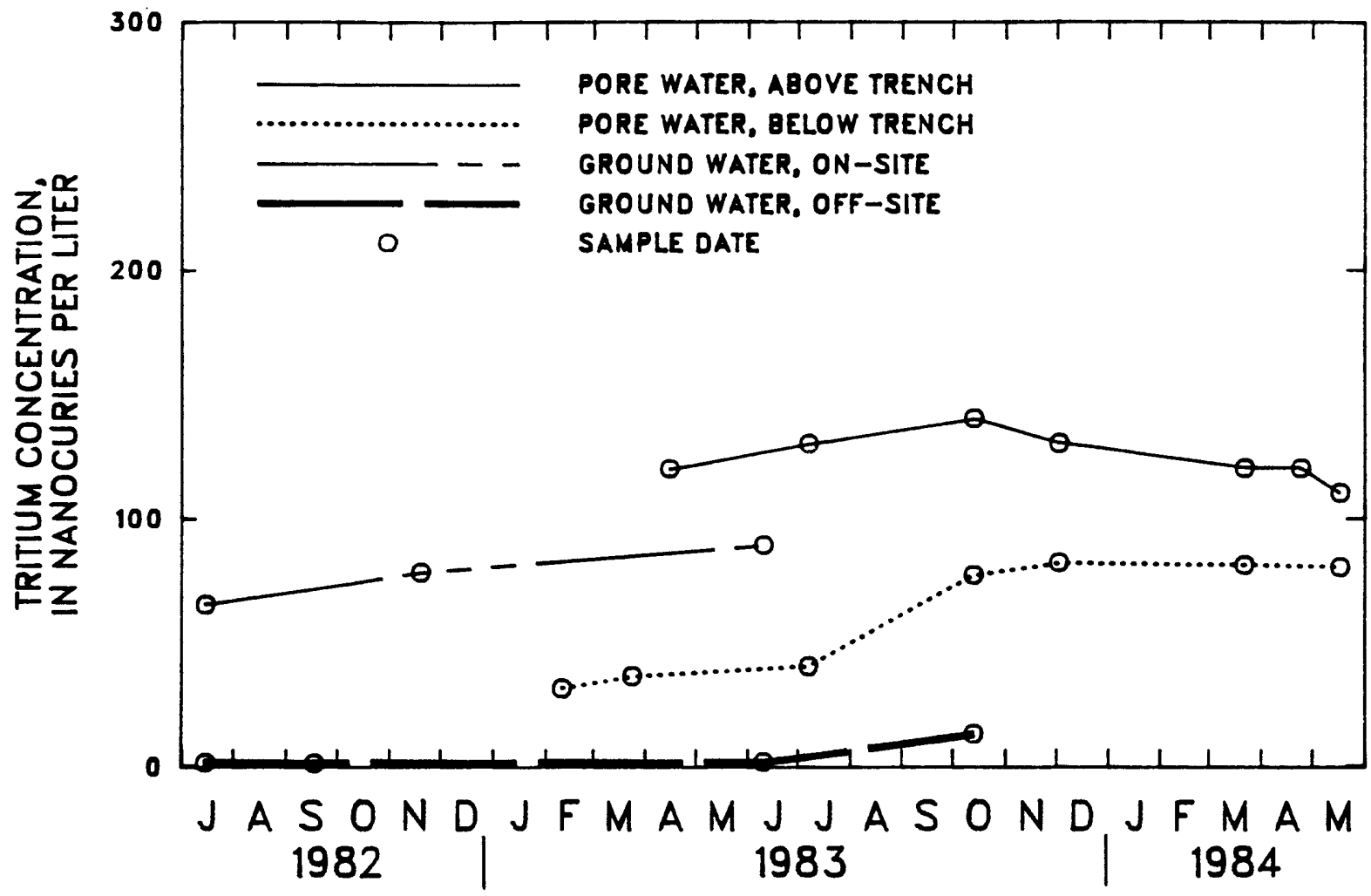

Figure 28.--Average concentration of tritium in pore water and ground water, July 1982 through May 1984.

\section{Contributing Influences}

Changes in water chemistry in the unsaturated zone resulted in part from dissolution reactions involving calcite, dolomite, and montmorillonite; the oxidation of pyrite; cation-exchange reactions; sorption of $z$ inc by iron- and manganese-oxides and hydroxides; precipitation of calcite and sulfate; and the transport of DOC and tritium from the trenches. Information gained from other unsaturated-zone flow studies at the Sheffield site (Foster and others, 1984; Mills and Healy, 1987) was used to construct water-flow paths that show the lysimeters that are hydraulically downgradient from one another. Flow paths and geochemical reactions that are thought to occur in each lithologic unit are shown in figure 29.

Average differences in chemistry of water between lysimeters located onsite and off-site are depicted in figure 30 and tables 10 and 11 . The major difference between on-site and off-site water chemistry was the elevated tritium and DOC concentrations and the slight decrease in sodium concentrations in on-site water; this difference is attributed to the effects of waste burial and removal of Roxana silt and Radnor Till Member from on-site.

Below-trench pore-water chemistry varied depending on proximity to the Toulon Member/Hulick Till Member interface. Lysimeters near the interface had 

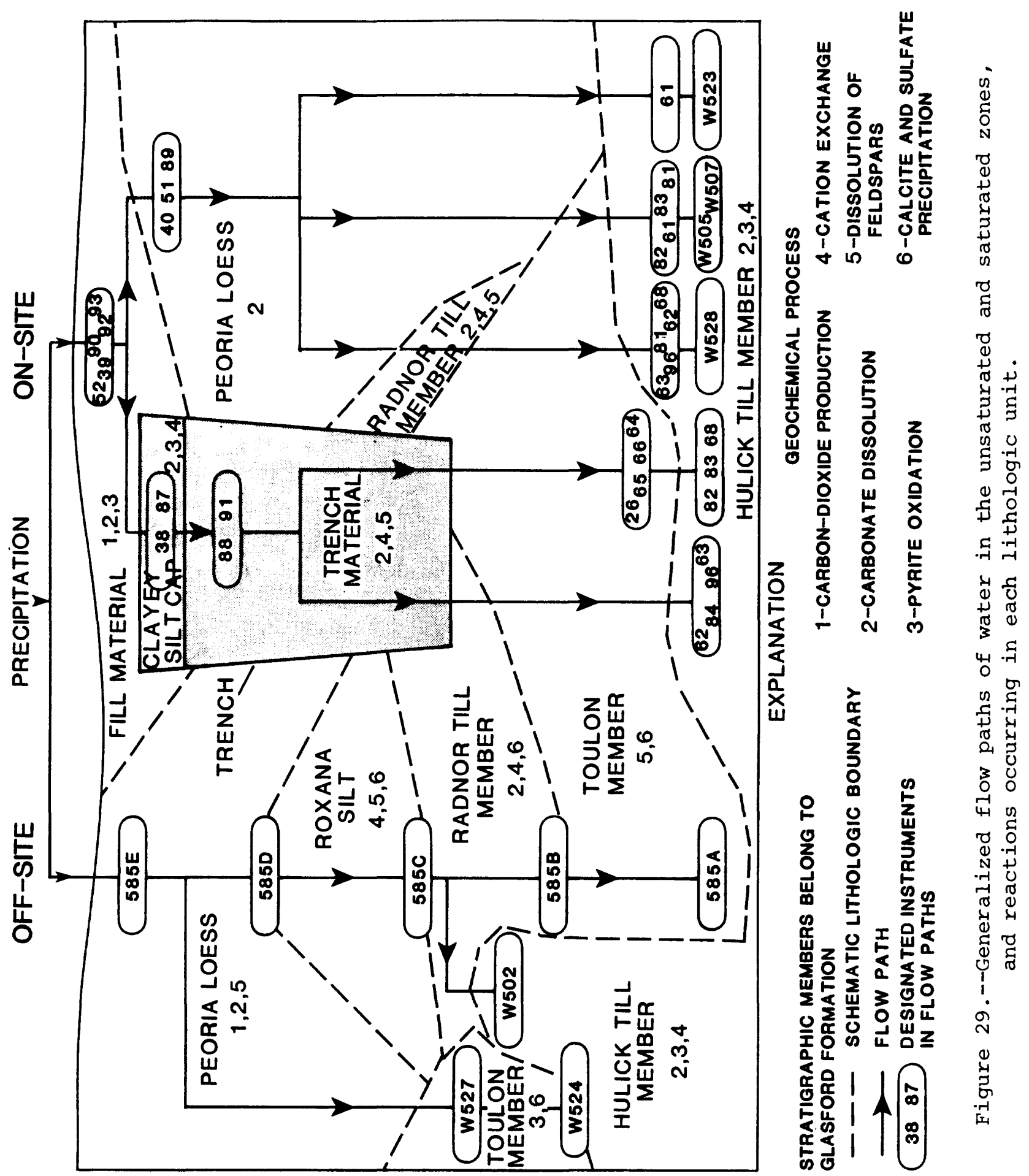

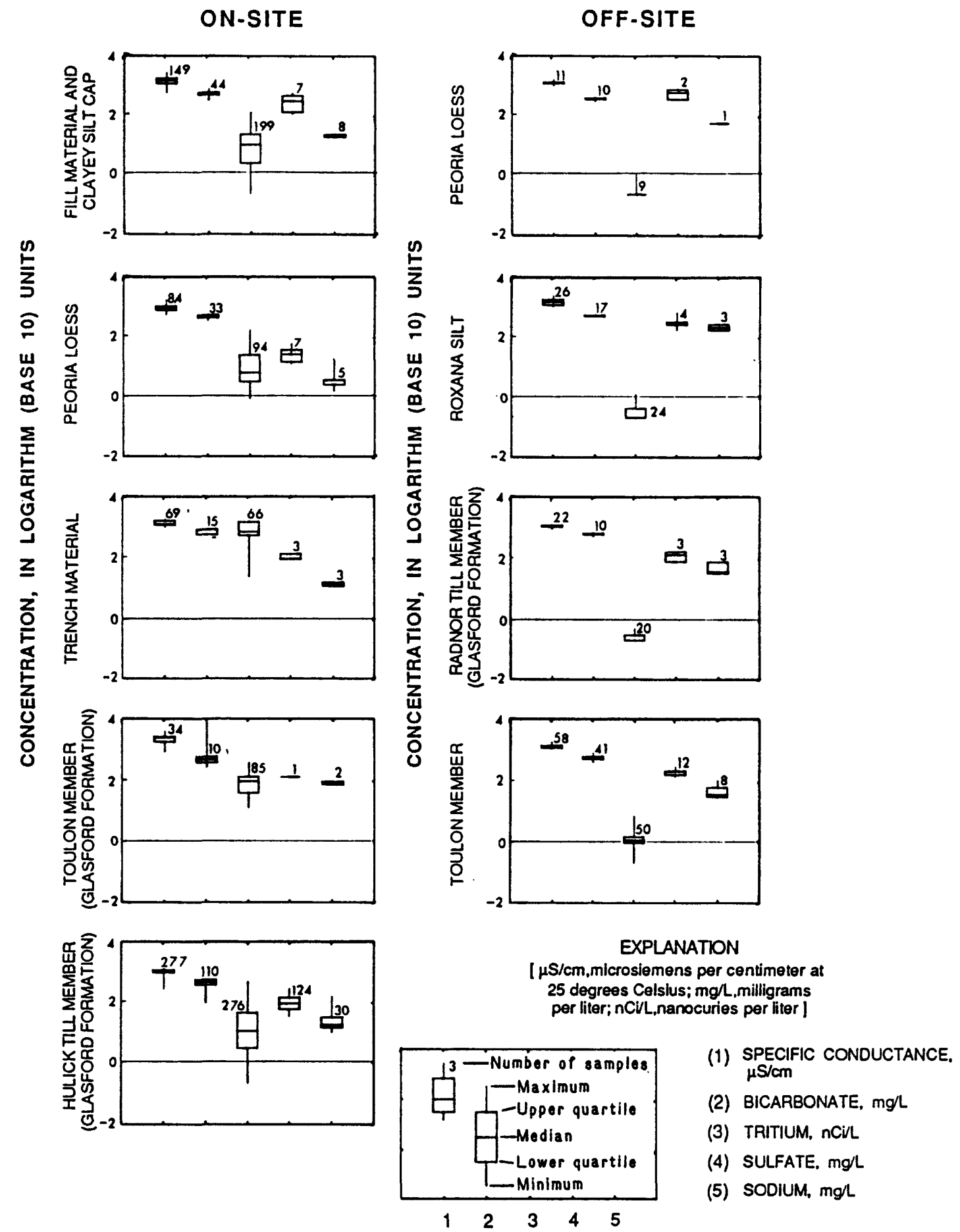

Figure 30.--Statistical summary of selected chemical properties in pore water in lithologic units on-site (above-trench and below-trench lysimeters) and off-site (borehole 585 lysimeters), June 1982 through June 1984. 
more seasonally varied water chemistry than those not near the interface; this may be explained by mixing of various chemistries of pore waters by lateral flow at the interface (M.P. deVries, U.S. Geological Survey, oral commun., 1985). The major effect of the trenches was to contribute DOC and tritium to the pore water.

Off-site, the Roxana silt contributed substantial quantities of sodium to solution from montmorillonite dissolution and associated cation-exchange reactions. The Radnor Till Member provided exchange surfaces for magnesium.

\section{SUMMARY}

The geologic materials found in undisturbed and disturbed unsaturated deposits were described and the change in chemistry of infiltrating water was defined at a low-level radioactive-waste disposal site near sheffield, Illinois. The ability to sample water effectively from the unsaturated zone using ceramic-cup soil-water pressure-vacuum lysimeters was evaluated.

Precipitation was collected in a stainless-steel collector six times during a 6-month period (June through December 1983). Pore water was collected monthly from 30 soil-water pressure-vacuum lysimeters during a 2-year period (1982-84). On-site lysimeters were installed above, within, and below trenches. Lysimeters that were located below trenches were installed through the wall of a $90-\mathrm{m}-1$ ong by $2-\mathrm{m}$-diameter tunnel that extends beneath trenches $11,3,2$, and 1. Five lysimeters were located $30 \mathrm{~m}$ east of the tunnel in undisturbed materials outside the site boundary. The saturated zone was sampled for 5 years (1978-83) as part of another study. Chemical data of water from seven wells near the lysimeters were compared to chemical data of water from the lysimeters.

The ionic composition of precipitation at the site was calcium zinc sulfate, and it had an average $\mathrm{pH}$ of 4.6. The average concentration of zinc in precipitation was $1,300 \mu \mathrm{g} / \mathrm{L}$. The ionic composition of precipitation infiltrating the unsaturated zone changed to calcium sulfate off-site and to calcium bicarbonate on-site within $0.3 \mathrm{~m}$ of the land surface and had an average pH of 7.9; below that depth, pH averaged 7.5 and generally was calcium magnesium bicarbonate.

Some variability in water type of pore water was noted. Pore water from one lysimeter installed in the Hulick Till Member of the Glasford Formation on-site was calcium magnesium sulfate, and pore water from one lysimeter in the Roxana silt of $f-s i t e$ was sodium bicarbonate sulfate. Alkalinity concentrations (as $\mathrm{CaCO}_{3}$ ) of pore water ranged from 87 to $820 \mathrm{mg} / \mathrm{L}$. The pH values ranged from 6.8 to 9.2 and were highest in water samples from the Toulon Member of the Glasford Formation. Dissolved-organic-carbon concentrations were higher than the background level in water from a few on-site lysimeters close to the trenches. Tritium was the only radionuclide found in the pore water. The highest concentration of tritium was $1,380 \mathrm{nCi} / \mathrm{L}$ in a pore-water sample collected from trench material. Median concentrations of tritium in pore water at above-trench and below-trench lysimeter locations were 11 and $18 \mathrm{nCi} / \mathrm{L}$, respectively. Tritium concentrations in the below-trench, tunnel-area geologic 
deposits ranged from 0.2 to $450 \mathrm{nCi} / \mathrm{L}$. Water chemistry was most variable near the sloping Toulon Member/Hulick Till Member interface, a major pathway for unsaturated-zone flow.

The ionic composition of water from the saturated zone was magnesium bicarbonate except in well 502, where it was sodium magnesium bicarbonate. The $\mathrm{pH}$ values of ground water ranged from 6.2 to 9.0 , and alkalinities ranged from 36 to $1,150 \mathrm{mg} / \mathrm{L}$. Average silica concentrations were lower in the saturated zone $(12 \mathrm{mg} / \mathrm{L})$ than in the unsaturated zone $(53 \mathrm{mg} / \mathrm{L})$. Dissolved-organiccarbon concentrations were near the background level in all wells. Tritium was the only radionuclide detected in the saturated zone and the highest concentration $(170 \mathrm{nCi} / \mathrm{L})$ was from a well on-site.

The highest specific conductances in the unsaturated zone occurred where the highest alkalinity and DOC concentrations occurred. The cations and anions that were dominant in the pore water also were dominant in the geologic materials.

Geochemical modeling indicated that nearly all unsaturated-zone pore water and saturated-zone waters were supersaturated with respect to calcite and dolomite. Concentrations of calcium, magnesium, and bicarbonate in unsaturated-zone pore water were increased by the dissolution of carbonates. Cation-exchange reactions caused concentrations of calcium and magnesium to decrease and concentrations of sodium to increase. The oxidation of pyrite was the likely source of sulfate at the site. On-site sulfate concentrations could be correlated with the amount of clayey silt materials present. Trench construction activities appear to account for low silica concentrations in pore water from on-site, near-surface sediments.

The major difference between on-site and off-site water chemistry was the higher tritium and DOC concentrations and reduced sodium concentrations on-site; this difference is attributed to the effects of waste burial and removal of the Roxana silt and the Radnor Till Member of the Glasford Formation from on-site.

Tritium and DOC concentrations were highest near the trenches. Tritium and DOC concentrations in ground water were near background levels in off-site areas. Tritium concentrations in ground water varied seasonally in on-site areas. Seasonally elevated tritium concentrations in water samples from the below-trench lysimeters result from increased percolation of pore water during the spring; elevated concentrations in the above-trench lysimeter samples occur during the summer as a result of increased evapotranspiration. Large increases in tritium concentrations in pore water from three below-trench lysimeters apparently coincided with large rainfall and the development of collapse holes in the trench surface above the tunnel. Both instantaneous and continuous releases in tritium from the trenches may occur, each represented by different patterns of increasing and decreasing pore-water tritium concentrations.

off-site, the Roxana silt contributed substantial quantities of sodium to solution from montmorillonite dissolution and associated cation-exchange reactions. The Radnor Till Member provided exchange surfaces for magnesium. 
Ceramic-cup soil-water pressure-vacuum lysimeters were determined to be an adequate means of collecting representative samples from the unsaturated zone. The constituents whose concentrations may have changed because of lysimeter-cup leaching and degassing were silica (concentrations increased), certain heavy metals (concentrations either increased or decreased depending on the metal), and $\mathrm{pH}$. All other major cations and anions appeared to be unaffected by the use of ceramic-cup pore-water pressure-vacuum lysimeters.

\section{SELECTED REFERENCES}

American Public Health Association, 1985, Standard methods for the examination of water and wastewater, 16th edition: Washington, D.C., American Public Health Association, 1,268 p.

Barnes, Ivan, 1964, Field measurement of alkalinity and pH: U.S. Geological Survey water-Supply Paper 1535-H, $17 \mathrm{p}$.

Blake, G.R., 1965, Bulk density, in Black, C.A. ed., Methods of soil analysis: Madison, Wisconsin, American Society of Agronomy, p. 374-390.

Bohn, H.L., McNeal, B.L., and O'Connor, G.A., 1979, Soil chemistry: New York, John wiley and Sons, 329 p.

Brackensiek, D.L., Osborn, H.B., and Rawls, w.J., coordinators, 1979, Field manual for research in agricultural hydrology: U.S. Department of Agriculture, Agricultural Handbook 224, 550 p.

Brady, N.C., 1974, The nature and properties of soils: New York, Macmillan Publishing Co., 639 p.

Broadbent, F.E., 1973, Organics, in Proceedings of the Joint Conference on Recycling Municipal Sludges and Effluents on Land, Champaign, Illinois, July 9-13, 1973: National Association of State Universities and Land-Grant Colleges, p. 97-101.

Brown, Eugene, Skougstad, M.W., and Fishman, M.J., 1970, Methods for collec$t$ ion and analysis of water samples for dissolved minerals and gases: U.S. Geological Survey Techniques of Water-Resources Investigations, Book 5, Chapter A1, 160 p.

Brunaer, S.E., Emmett, P.H., and Teller, E., 1938, Adsorption of gases in multimolecular layers: Journal of the American Chemical Society, v. 60, p. 309-319.

Buhler, Shirrell, Firester, L., Buhler, R., Heiberger, R.M., and Laurance, D., 1983, P-STAT users manual: Princeton, New Jersey, P-STAT Inc., 719 p.

Butler, J.N., 1982, Carbon dioxide equilibria and their applications: Reading, Massachusetts, Addison-Wesley Publishing Co., 259 p.

Chapelle, F.H., and Knobel, L.L., 1983, Aqueous geochemistry and the exchangeable cation composition of glauconite in the Aquia aquifer, Maryland: Groundwater, v. 21, no. 3, p. 343-352.

Chapman, H.D., 1965, Cation exchange capacity, in Black, C.A., ed., Methods of soil analysis: Madison, Wisconsin, American Society of Agronomy, p. 896-898.

Claassen, H.C., 1982, Guidelines and techniques for obtaining water samples that accurately represent the water chemistry of the aquifer: U.S. Geological Survey Open-File Report 82-1024, 49 p.

Crouthamel, C.E., 1970, Applied gamma-ray spectrometry: Second edition revised by F. Adams, and R. Dams, Oxford, Pergamon Press, 747 p. 
Day, P.R., 1965, Particle size analysis, in Black, C.A., ed., Methods in soil analysis: Madison, Wisconsin, American Society of Agronomy, p. 545-566.

Dreimanis, Aleksis, 1962, Quantitative gasometric determination of calcite and dolomite by using chittick apparatus: Journal of Sedimentary Petrology, v. 32, no. 3, p. 520-529.

Drever, J.F., 1982, The Geochemistry of natural waters: Englewood Cliffs, New Jersey, Prentice-Hall, 388 p.

Foster, J.B., and Erickson, J.R., 1980, Preliminary report on the hydrogeology of a low-level radioactive-waste disposal site near Sheffield, Illinois: U.S. Geological Survey Open-File Report 79-1545, 87 p.

Foster, J.B., Erickson, J.R., and Healy, R.W., 1984, Hydrogeology of a lowlevel radioactive-waste disposal site near Sheffield, Illinois: U.S. Geological Survey Water-Resources Investigations Report 83-4125, 83 p.

Foster, J.B., Garklavs, George, and Mackey, G.W., 1984a, Geologic and hydrologic data collected during 1976 to 1984 at the Sheffield low-level radioactive-waste disposal site and adjacent areas, Sheffield, Illinois: U.S. Geological Survey Open-File Report 83-926, 261 p.

---- 1984b, Hydrogeologic setting east of a low-level radioactive-waste disposal site near Sheffield, Illinois: U.S. Geological Survey WaterResources Investigations Report 84-4183, 20 p.

Freeze, A.R., and Cherry, J.A., 1979, Groundwater: Englewood Cliffs, New Jersey, Prentice Hall, 604 p.

Garklavs, George, and Healy, R. W., 1986, Hydrogeology, ground-water flow, and tritium migration at a low-level radioactive-waste disposal site near Sheffield, Illinois: U.S. Geological Survey Water-Resources Investigations Report 86-4153, 35 p.

Gray, J.R., and McGovern, L.L., 1986, Collapse and erosion at the low-level radioactive-waste burial site near Sheffield, Illinois, in Proceedings of the Seventh Annual Participants Information Meeting DOE Low-Level Waste Management Program: Department of Energy, CONF-8509121, p. 737-753.

Hansen, E.A., and Harris, A.R., 1975, Validity of soil water samples collected with porous ceramic cups: Soil Science Society of America Proceedings, v. 39, p. 528-536.

Healy, R.W., 1989, Seepage through a hazardous-waste trench cover: Journal of Hydrology, v. 108, no. 1-4, p. 213-234.

Healy, R.w., deVries, M.P., and Striegl, R.G., 1986, Concepts and datacollection techniques used in a study of the unsaturated zone at a lowlevel radioactive-waste disposal site near Sheffield, Illinois: U.S. Geological Survey Water-Resources Investigations Report 85-4228, 37 p.

Healy, R.W., deVries, M.P., and Sturrock, A.M., Jr., 1989, Evapotranspiration and microclimate at a low-level radioactive-waste disposal site in northwestern Illinois: U.S. Geological Survey Water-Supply Paper 2327, 44 p.

Hem, J.D., 1972, Geochemical controls of groundwater quality, in Proceedings of the Fourteenth water-Quality Conference, Groundwater Quality and Treatment, Champaign, Illinois: University of Illinois Bulletin, v. 69, no. 120 , p. 7-18.

-.-- 1985, Study and interpretation of the chemical characteristics of natural water: U.S. Geological Survey Water-Supply Paper 2254, 3 rd edition, 263 p. 
Henderson, Thomas, 1984, Geochemistry of ground-water in two sandstone aquifer systems in the northern great plains in parts of Montana, Wyoming, North Dakota, and South Dakota: U.S. Geological Survey Professional Paper 1402-C, 84 p.

Hendry, M.J., Cherry, J.A., Wallick, E.I., 1986, Origin and distribution of sulfate in a fractured till in southern Alberta, Canada: Water Resources Research, v. 22, no. 1, p. 45-61.

Horr, C.A., 1959, Methods for the determination of strontium in natural water: U.S. Geological Survey Water-Supply Paper 1496-A, 30 p.

Hostetler, P.B., 1964, The degree of saturation of magnesium and calcium carbonate minerals in natural waters: International Association of Science Hydrology Commission of Subterranean Waters Publication 64, p. 34-49.

Hurlbut, C.S., and Klein, Cornelis, 1977, Manual of mineralogy: New York, John Wiley and Sons, 532 p.

Illinois Environmental Protection Agency, 1982, Manual of lab methods: Springfield, Illinois, Division of Labs, 1,028 p.

Jenne, E.A., 1977, Trace element sorption by sediments and soils--sites and processes, in Chappel, W., and Petersen, K., eds., Symposium on Molybdenum in the Environment, v. 2: New York, Marcel Dekker, p. 425-553.

Johnson, T.M., and Cartwright, Keros, 1980, Monitoring of leachate migration in the unsaturated zone in the vicinity of sanitary landfills: Illinois State Geological Survey Circular 514, 82 p.

Levin, M., and Verhagen, B.Th., 1985, Soil moisture studies in the unsaturated zone at the South African nuclear waste repository facility, in Hydrology of Rocks of Low Permeability: International Association of Hydrogeologists, Memoires, v. 17, part 1, p. 236-247.

Lovering, T.S., 1959, Significance of accumulator plants in rock weathering: Geological Society of America Bulletin, v. 70, p. 781-800.

Martland, M.M., and Kemper, W.D., 1965, Surface area, in Black, C.A., ed., Methods of soil analysis: Madison, Wisconsin, American Society of Agronomy, p. 532-544.

Means, J.L., Crerar, D.A., Borcsik, M.P., and Duguid, J.O., 1978, Adsorption of $\mathrm{Co}$ and selected actinides by $\mathrm{Mn}$ and $\mathrm{Fe}$ oxides in soils and sediments: Geochimica et Cosmochimica Acta, v. 42, p. 1763-1773.

Mills, P.C., and Healy, R.W., 1987, water and tritium movement through variably saturated glacial deposits at a low-level radioactive-waste disposal site near Sheffield, Illinois, in Proceedings of the FOCUS Conference on Midwestern Ground Water Issues, Indianapolis, Indiana: National Water Well Association, p. 169-186.

----- 1991, water and tritium movement through the unsaturated zone at a lowlevel radioactive-waste disposal site near Sheffield, Illinois, 1981-85: U.S. Geological Survey Open-File Report 89-271, 109 p.

Moran, S.R., Groenewold, G.H., and Cherry, J.A., 1978, Geologic, hydrologic, and geochemical concepts and techniques in overburden characterization for mined-land reclamation: North Dakota Geological Survey Report of Investigations No. 63, 152 p.

Nuclear Measurements Corporation, 1975, Instruction manual, proportional Counting System--NMC Model PC-5, 22 p.

Parkhurst, D.L., Plummer, L.N., and Thorstenson, D.C., 1982, BALANCE--a computer program for calculating mass transfer for geochemical reactions in ground water: U.S. Geological Survey Water-Resources Investigations 82-14, 33 p. 
Peters, C.A., and Healy, R.W., 1988, Representiveness of pore-water samples collected from the unsaturated zone using pressure-vacuum lysimeters: Ground water Monitoring Review, v. 8, p. 96-101.

Piciulo, Paul, Shea, C.E., and Barletta, R.E., 1982, Analysis of soil from an area adjacent to a low-level radioactive-waste disposal site, at Sheffield, Illinois: Brookhaven National Laboratory, BNL-NUREG-31667, $43 \mathrm{p}$.

Pietrzak, R.F., and Dayal, R., 1982, Evaluation of isotope migration--1and burial water chemistry at a commercially operated low-level radioactivewaste disposal site: Brookhaven National Laboratory, BNL-NUREG-31567, $34 \mathrm{p}$.

Piper, A.M., 1944, A graphical procedure in the geochemical interpretation of water analyses: American Geophysical Union Transcripts, v. 25, p. 914-923.

Piskin, Kemal, and Bergstrom, R.E., 1975, Glacial drift in Illinois--thickness and character: Illinois State Geological Survey Circular 490, 35 p.

Plummer, L.N., Jones, B.F., and Truesdale, A.H., 1976, WATEQF--a Fortran IV version of WATEQ, a computer program for calculating chemical equilibria of natural waters: U.S. Geological survey water-Resources Investigations $76-13,61 \mathrm{p}$.

Plummer, L.N., Wigley, T.M.L., and Parkhurst, D.L., 1978, The kinetics of calcite dissolution in $\mathrm{CO}_{2}$-water systems at 5 to $60^{\circ} \mathrm{C}$ and 0.0 to 1.0 atm $\mathrm{CO}_{2}$ : American Journal of Science, v. 278, no. 2, p. 179-216.

Reardon, E.J., Mozeto, A.A., and Fritz, P., 1980, Recharge in northern clime calcareous sandy soils: Soil water chemical and carbon-14 evolution: Geochimica et Cosmochimica Acta, v. 44, p. 1723-1735.

Reesman, A.L., Walton, A.W., Sprinkle, C.L., Godfrey, A.E., and Smith, D.B., 1975, Hydro-geochemistry in a carbonate basin-geomorphic and environmental implications: Water Resources Research Center, University of Tennessee, Resources Report No. 44, 261 p.

SAS Institute, Inc., 1982, SAS user's guide: Statistics, 1982 edition: Cary, North Carolina, 921 p.

Shepard, F.P., 1954, Nomenclature based on sand-silt-clay ratios: Journal of Sedimentary Petrology, v. 24, no. 3, p. 151-158.

Skougstad, M.W., and Horr, C.A., 1963, Occurrence and distribution of strontium in natural water: U.S. Geological Survey Water-Supply Paper 1496-D, p. 55-97.

Skougstad, M.W., Fishman, M.J., Friedman, L.C., Erdmann, D.E., and Duncan, Sandra, editors, 1979, Methods for determination of inorganic substances in water and fluvial sediments: U.S. Geological Survey Techniques of Water-Resources Investigations, Book 5, Chapter A1, 626 p.

State of Illinois, Department of Registration and Education, 1958, At las of Illinois resources, Section 1: Water Resources and Climate: Division of Industrial Planning and Development, $58 \mathrm{p}$.

Striegl, R.G., 1988, Distribution of gases in the unsaturated zone at a lowlevel radioactive-waste disposal site near Sheffield, Illinois: U.S. Geological Survey Water-Resources Investigations Report 88-4025, 69 p.

striegl, R.G., and Ruhl, P.M., 1986, Variability in the partial pressures of gases in the unsaturated zone adjacent to a low-level radioactivewaste disposal site near Sheffield, Illinois, in Proceedings of Seventh Annual Participants Information Meeting DOE Low-Level Waste Management Program: Department of Energy, CONF-8509121, p. 725-736. 
Stumm, Werner, and Morgan, J.J., 1981, Aquatic chemistry, Second edition: New York, Wiley Interscience, $780 \mathrm{p}$.

Suarez, D.L., 1982, Graphical calculation of ion concentration in calcium carbonate and/or gypsum soil solutions: Journal of Environmental Quality, v. 11, no. 2, p. 302-308.

----- 1986, A soil water extractor that minimizes $\mathrm{CO}_{2}$ degassing and pH errors: Water Resources Research, v. 22, no. 6, p. 876-880.

Thatcher, L.L., Janzer, V.J., and Edwards, K.K., 1977, Methods for determination of radioactive substances in water and fluvial sediments: U.S. Geological Survey Techniques of Water-Resources Investigations, Book 5, Chapter A5, 95 p.

Thornburn, T.H., 1963, Surface deposits of Illinois--a guide for soil engineers: Urbana, Illinois, University of Illinois Engineering Experiment Station Circular No. 80, 135 p.

Thorstenson, D.C., Fisher, D.W., and Croft, M.G., 1979, The geochemistry of the Fox Hills-Basal Hell Creek Aquifer in southwestern North Dakota and northwestern South Dakota: Water Resources Research, v. 15, no. 6, p. 1479-1498.

Thorstenson, D.C., Weeks, E.P., Haas, H., and Fisher, D.W., 1983, Distribution of gaseous $\mathrm{CO}_{2}$ in the subsoil unsaturated zone of the western U.S. Great Plains: Radiocarbon, v. 25, no. 2, p. 315-346.

Tsai, T.C., Morrison, R.D., and Stearns, R.J., 1980, Validity of the porous cup vacuum/suction lysimeter as a sampling tool for vadose zone waters: Huntington Beach, California, Calscience Research, Inc. (unpublished report), $11 \mathrm{p}$.

Turkenian, K.K., and Kulp, J.L., 1956, Geochemistry of strontium: Geochemica et Cosmochimica Acta, v. 10, p. 245-296.

U.S. Department of Commerce, National Oceanic and Atmospheric Administration, 1939-79, Climatological data for Illinois, annual summary: Asheville, North Carolina, Environmental Data Information Service, National Climatic Center.

U.S. Envi ronmental Protection Agency, 1976, Quality criteria for water, 256 p.

U.S. Nuclear Regulatory Commission, 1975, 10CFR, 20, B, II.

van Lier, J.A., de Bruyn, P.L., and Overbeek, J.Th.G., 1960, The solubility of quartz: Journal of Physical Chemistry, v. 64, p. 1675-1682.

Verhagen, B.Th., Smith, P.E., McGeorge, I., and Dziembowski, Z., 1979, Tritium profiles in Kalahari sands as a measure of rain-water recharge, in Proceedings of an International Symposium on Isotope Hydrology, June 19-23, 1978, Neuherberg, Germany: Vienna, Austria, International Atomic Energy Agency, v. 2, p. 733.

Vomocil, J.A., 1965, Porosity, in Black, C.A., ed.: Methods of soil analysis: Madison, wisconsin, American Society of Agronomy, p. 299-314.

Wallace, Debbie, 1980, Water quality provinces of Illinois: Illinois Water Information System Report of Investigation No. 27, 82 p.

Warrick, A.W., and Amoozegar-Fard, A., 1977, Soil-water regimes near porous cup water samplers: Water Resources Research, v. 13, no. 1, p. 203-207.

Willman, H.B., and Frye, J.C., 1970, Pleistocene stratigraphy of Illinois: Illinois State Geological Survey Bulletin 94, 204 p.

Wolfe, R.G., 1967, Weathering of Woodstock Granite near Baltimore, Maryland: American Journal of Science, v. 265, p. 106-117.

Wood, W.W., and Signor, D.C., 1975, Geochemical factors affecting artificial recharge in the unsaturated zone: Water Resources Research, v. 9, no. 2, p. 486-488. 

TABLES 14 to 20 
Table 14.--Physical characteristics of water-chemistry sampling sites

$$
\text { [m, meters ] }
$$

\begin{tabular}{|c|c|c|c|c|}
\hline $\begin{array}{l}\text { Site } \\
\text { number } \\
\text { (see } \\
\text { fig. 6) }\end{array}$ & $\begin{array}{l}\text { Type of } \\
\text { sampling } \\
\text { site }\end{array}$ & Location & $\begin{array}{l}\text { Height } \\
\text { above } \\
\text { land } \\
\text { surface } \\
\text { (m) }\end{array}$ & $\begin{array}{c}\text { Sample } \\
\text { material }\end{array}$ \\
\hline 0001 & Precipitation & Off-site & 2.5 & $\begin{array}{r}\text { Atmospheric } \\
\text { deposition }\end{array}$ \\
\hline $\begin{array}{l}\text { Site } \\
\text { number } \\
\text { (see } \\
\text { fig. 6) }\end{array}$ & $\begin{array}{c}\text { Type of } \\
\text { sampling } \\
\text { site }\end{array}$ & Location & $\begin{array}{l}\text { Depth } \\
\text { below } \\
\text { land } \\
\text { surface } \\
\text { (m) }\end{array}$ & $\begin{array}{l}\text { Geologic } \\
\text { material }\end{array}$ \\
\hline
\end{tabular}

\begin{tabular}{|c|c|c|c|c|}
\hline $\begin{array}{l}585 A \\
585 B \\
585 C \\
585 D \\
585 E\end{array}$ & $\begin{array}{l}\text { Lysimeter } \\
\text { do. } \\
\text { do. } \\
\text { do. } \\
\text { do. }\end{array}$ & $\begin{array}{l}\text { off-site } \\
\text { do. } \\
\text { do. } \\
\text { do. } \\
\text { do. }\end{array}$ & $\begin{array}{r}13.1 \\
10.1 \\
6.7 \\
3.5 \\
1.2\end{array}$ & $\begin{array}{l}\text { Toulon Member }{ }^{1} \\
\text { Toulon Member } \\
\text { Radnor Till Member }{ }^{1} \\
\text { Roxana Silt } \\
\text { Peoria Loess }\end{array}$ \\
\hline $\begin{array}{l}38 \\
39 \\
40 \\
51 \\
52\end{array}$ & $\begin{array}{l}\text { do. } \\
\text { do. } \\
\text { do. } \\
\text { do. } \\
\text { do. }\end{array}$ & $\begin{array}{l}\text { On-site, above trench } \\
\text { do. } \\
\text { do. } \\
\text { do. } \\
\text { do. }\end{array}$ & $\begin{array}{r}1.4 \\
.6 \\
1.0 \\
.5 \\
.3\end{array}$ & $\begin{array}{l}\text { Clayey silt cap } \\
\text { Fill material } \\
\text { Peoria Loess } \\
\text { Peoria Loess } \\
\text { Fill material }\end{array}$ \\
\hline $\begin{array}{l}87 \\
88 \\
89 \\
90 \\
91\end{array}$ & $\begin{array}{l}\text { do. } \\
\text { do. } \\
\text { do. } \\
\text { do. } \\
\text { do. }\end{array}$ & $\begin{array}{l}\text { do. } \\
\text { do. } \\
\text { do. } \\
\text { do. } \\
\text { do. }\end{array}$ & $\begin{array}{r}1.1 \\
2.3 \\
1.3 \\
.7 \\
2.2\end{array}$ & $\begin{array}{l}\text { Clayey silt cap } \\
\text { Trench material } \\
\text { Peoria Loess } \\
\text { Fill material } \\
\text { Trench material }\end{array}$ \\
\hline $\begin{array}{l}92 \\
93\end{array}$ & $\begin{array}{l}\text { do. } \\
\text { do. }\end{array}$ & $\begin{array}{l}\text { do. } \\
\text { do. }\end{array}$ & $\begin{array}{r}1.0 \\
.4\end{array}$ & $\begin{array}{l}\text { Fill material } \\
\text { Fill material }\end{array}$ \\
\hline $\begin{array}{l}26 \\
61 \\
62 \\
63 \\
64\end{array}$ & $\begin{array}{l}\text { do. } \\
\text { do. } \\
\text { do. } \\
\text { do. } \\
\text { do. }\end{array}$ & $\begin{array}{l}\text { On-site, below trench } \\
\text { do. } \\
\text { do. } \\
\text { do. } \\
\text { do. }\end{array}$ & $\begin{array}{r}11.6 \\
7.0 \\
11.6 \\
11.6 \\
11.6\end{array}$ & $\begin{array}{l}\text { Toul on Member } \\
\text { Hulick Till Member } \\
\text { Hulick Till Member } \\
\text { Hulick Till Member } \\
\text { Toul on Member }\end{array}$ \\
\hline
\end{tabular}


Table 14.--Physical characteristics of water-chemistry sampling sites--Continued

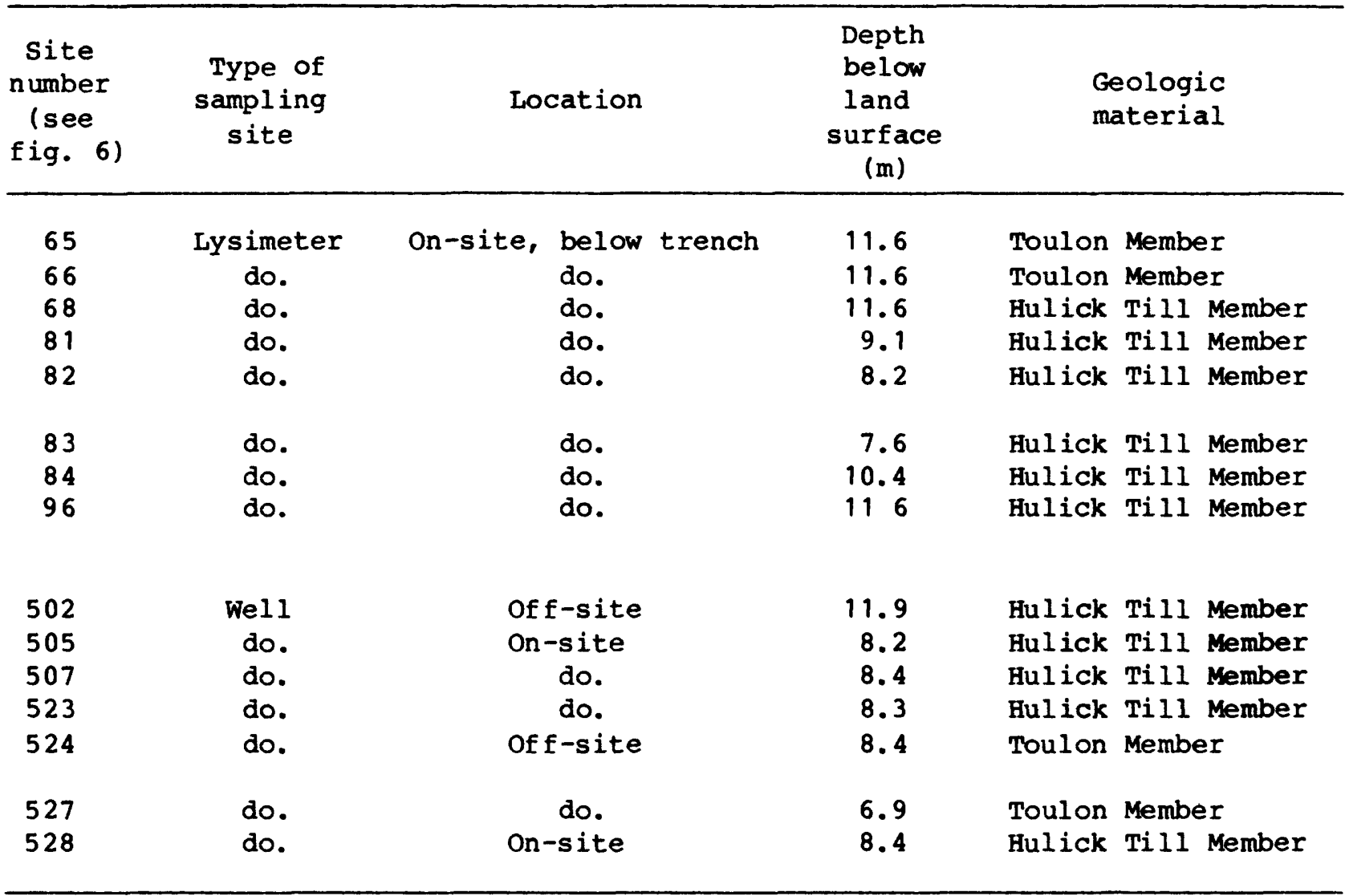

lof the Glasford Formation. 


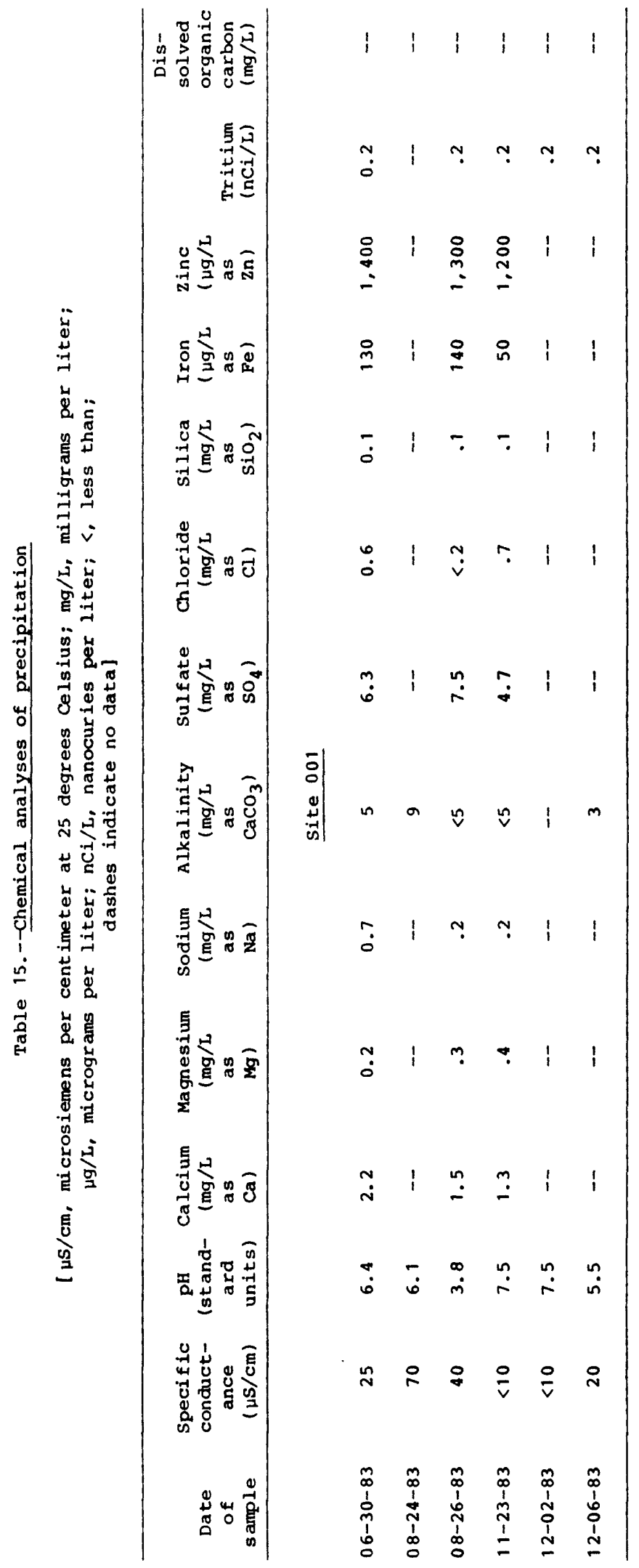




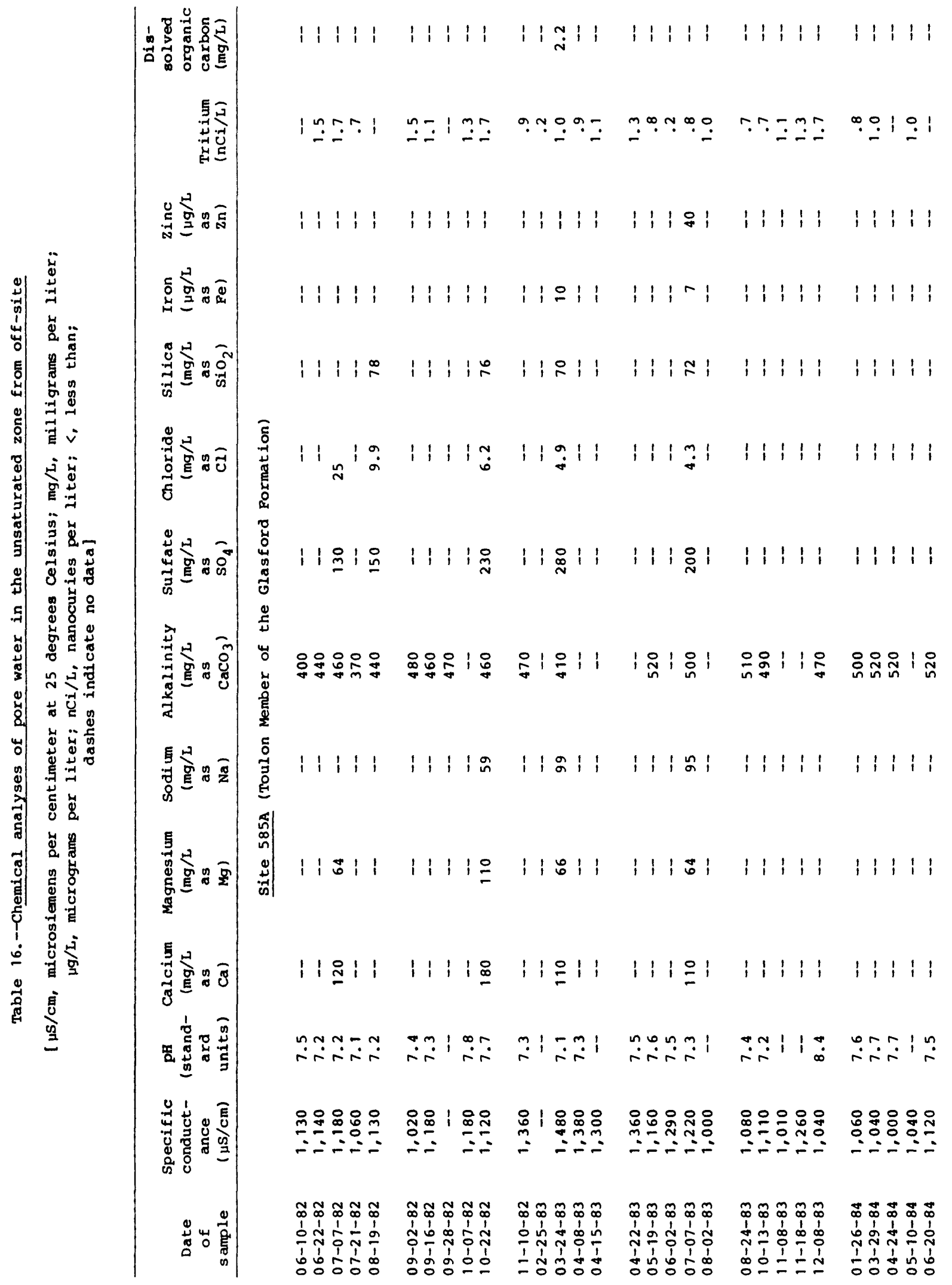




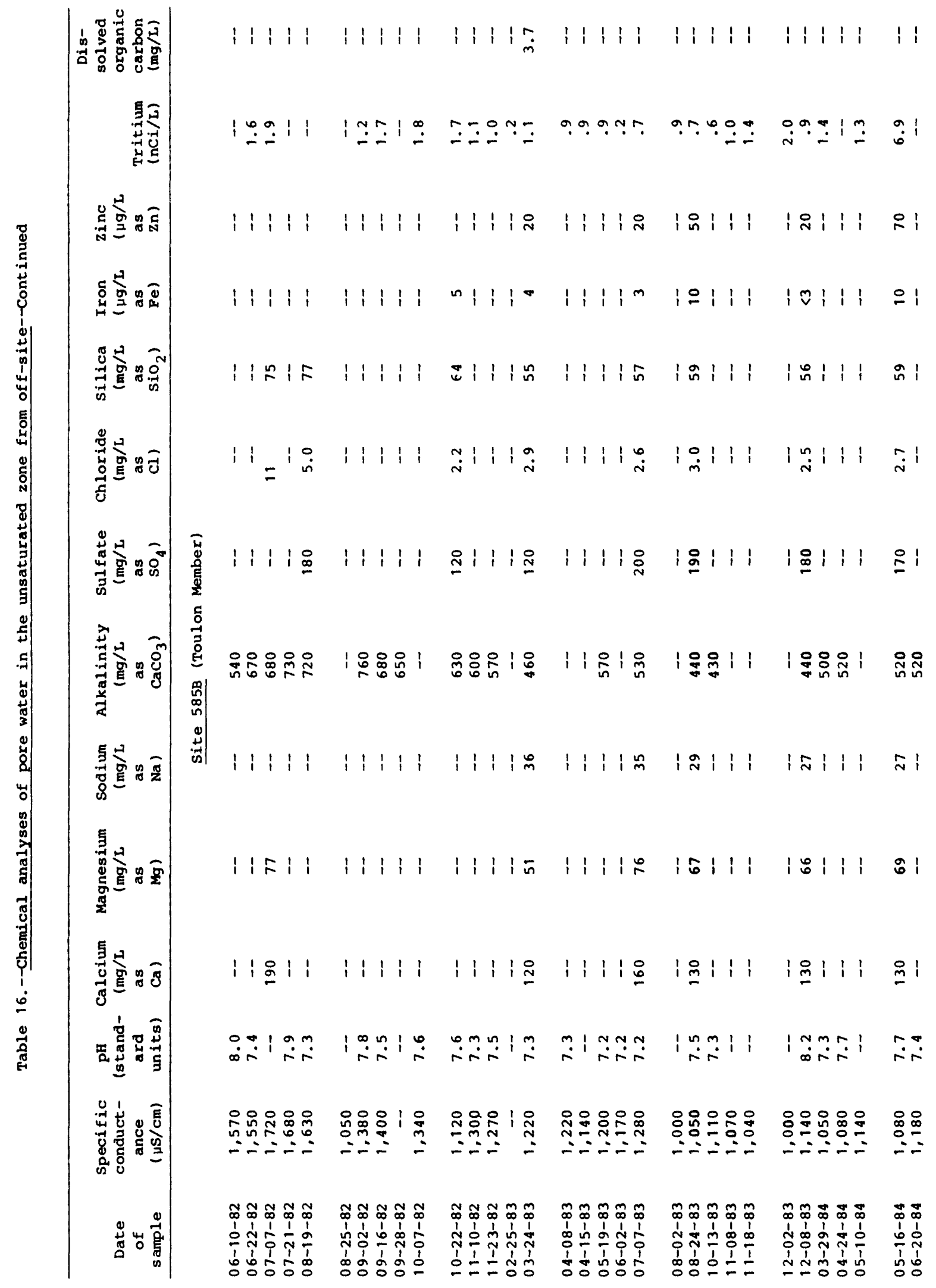




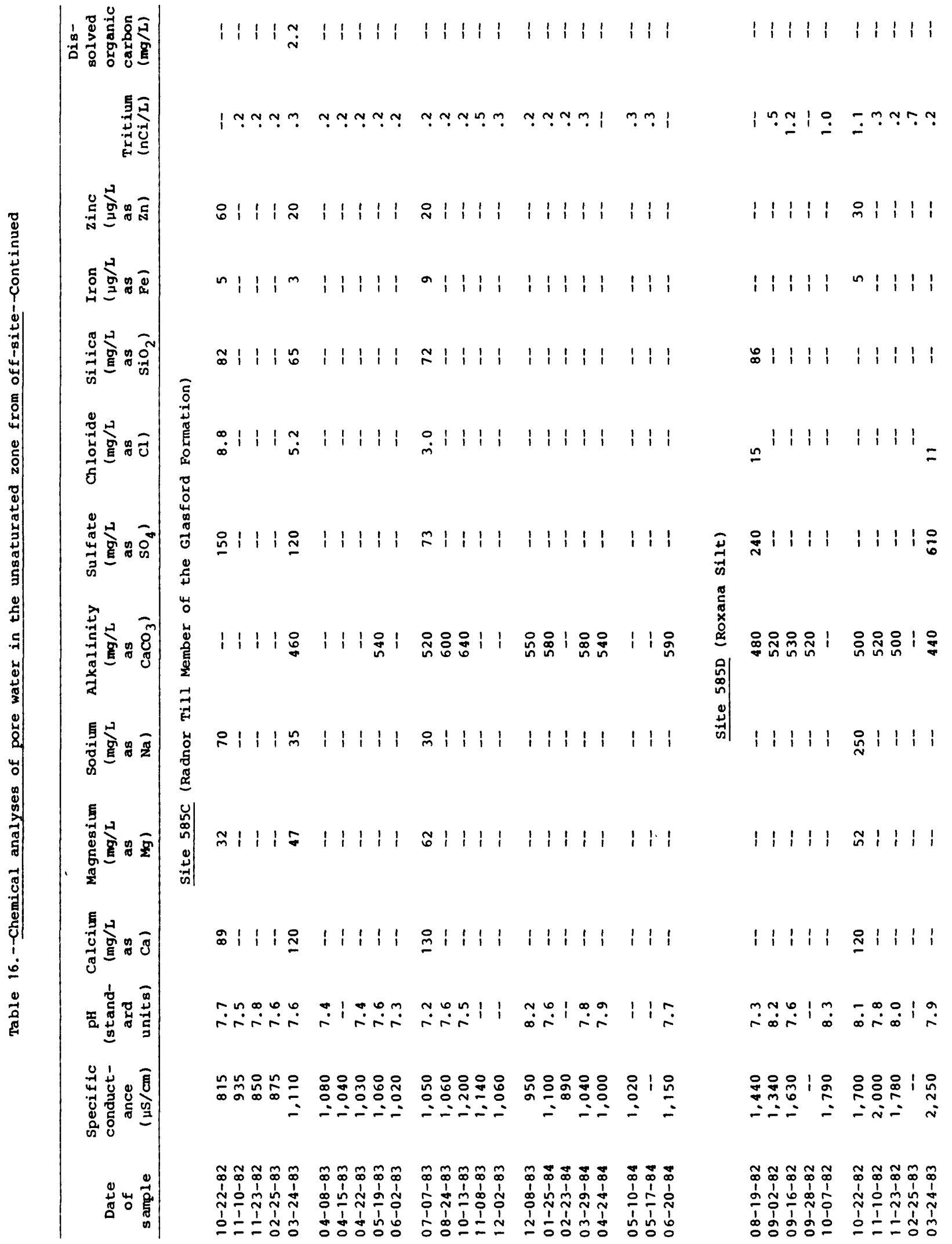




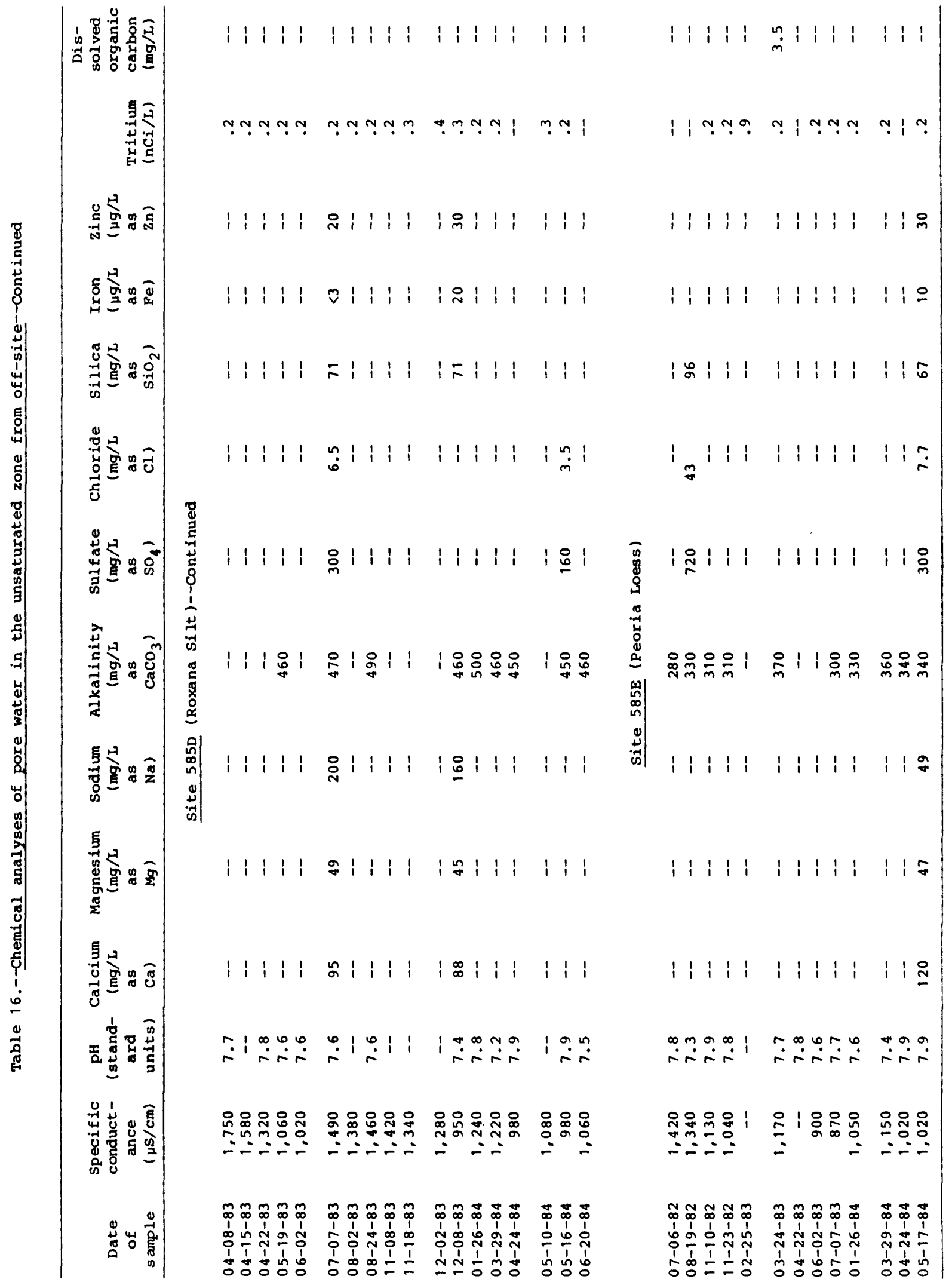




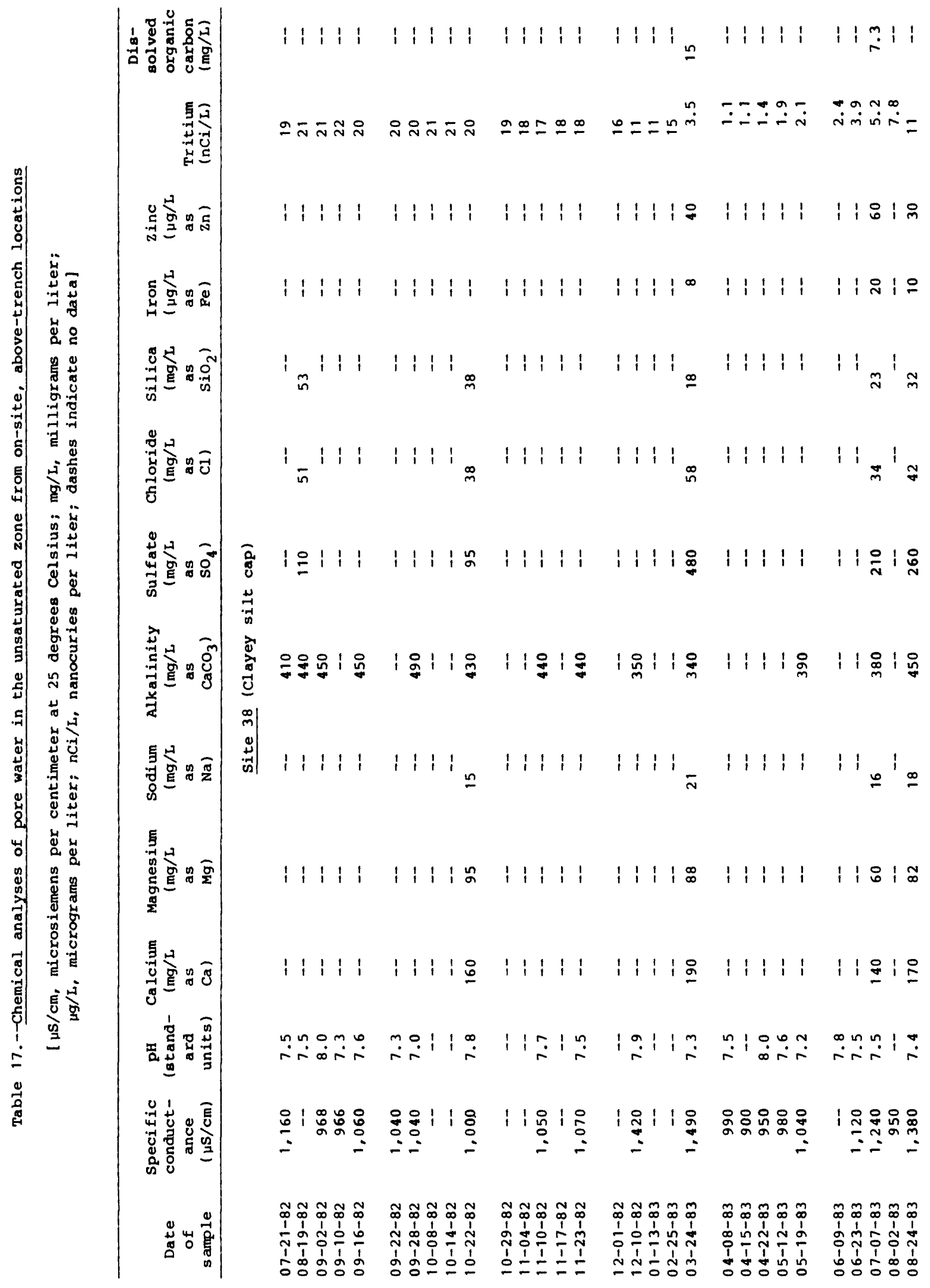




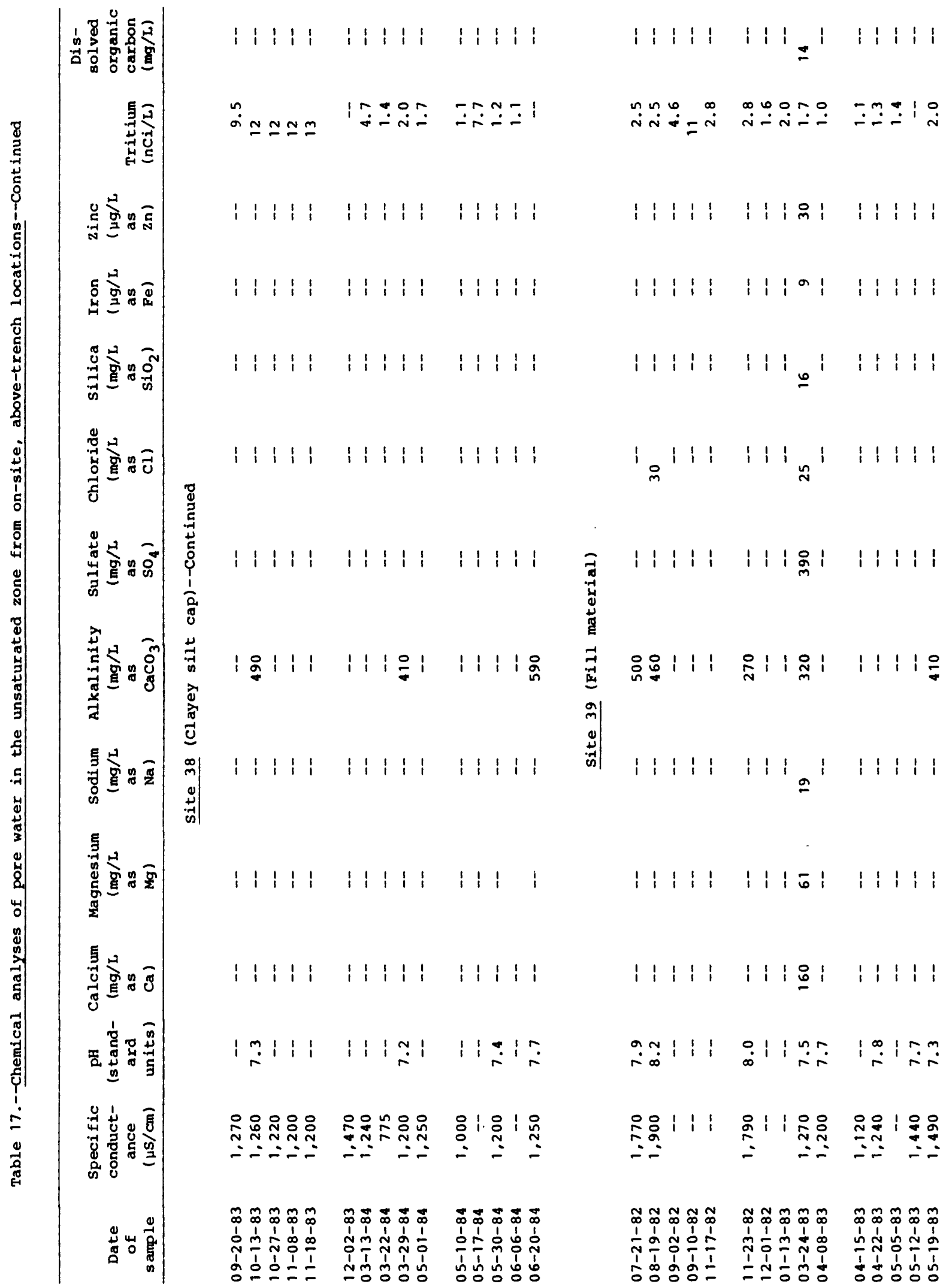




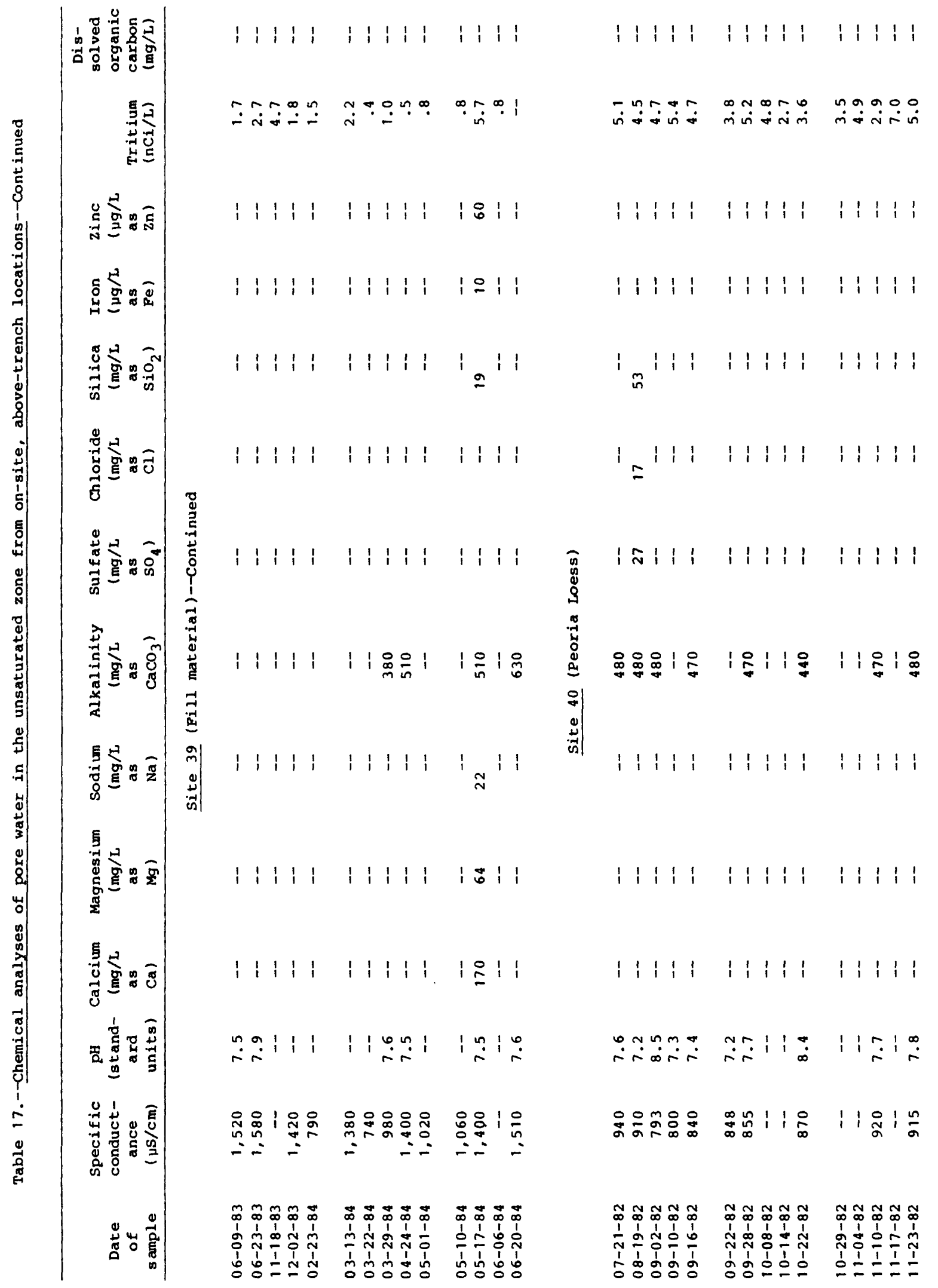




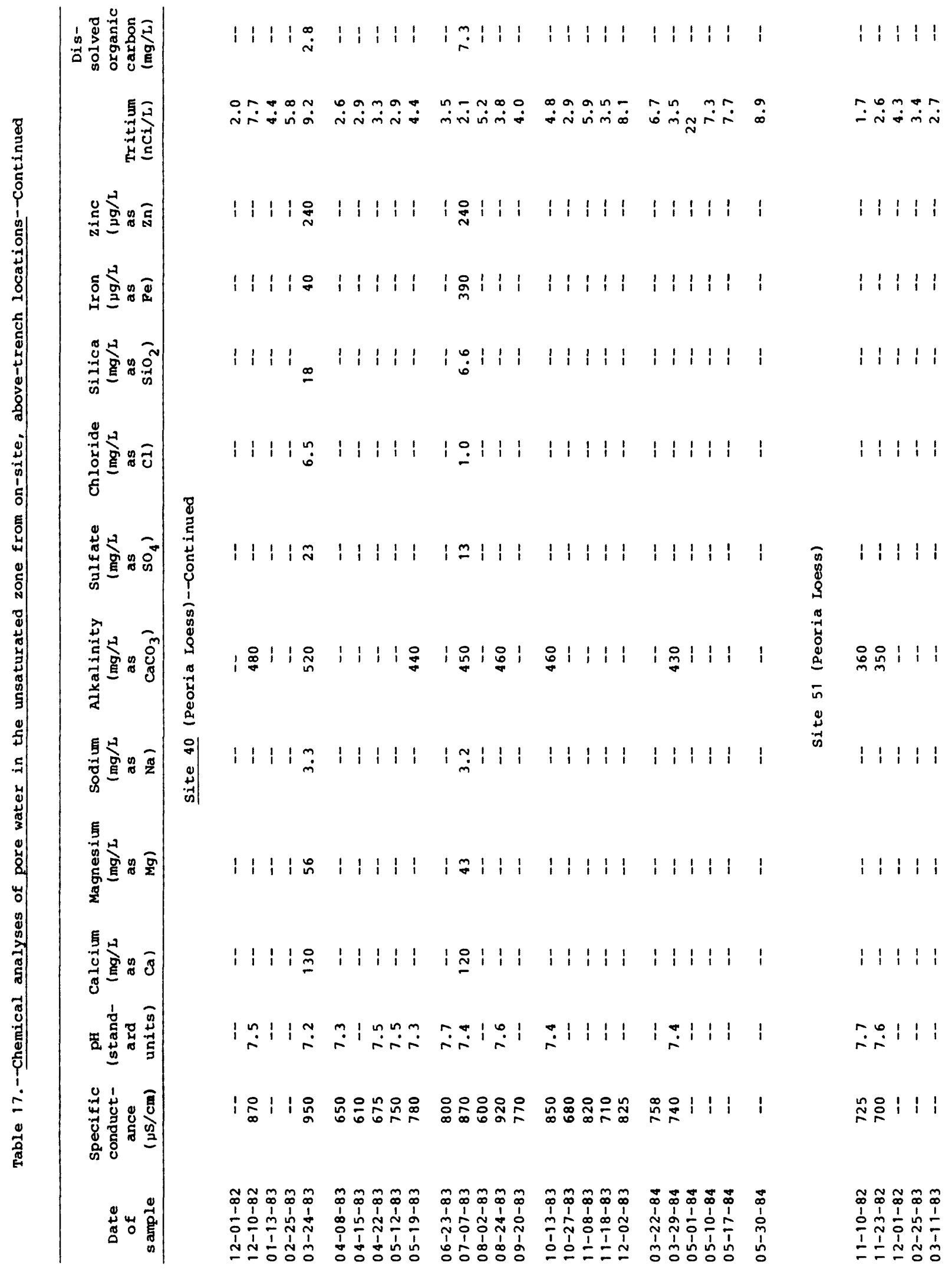




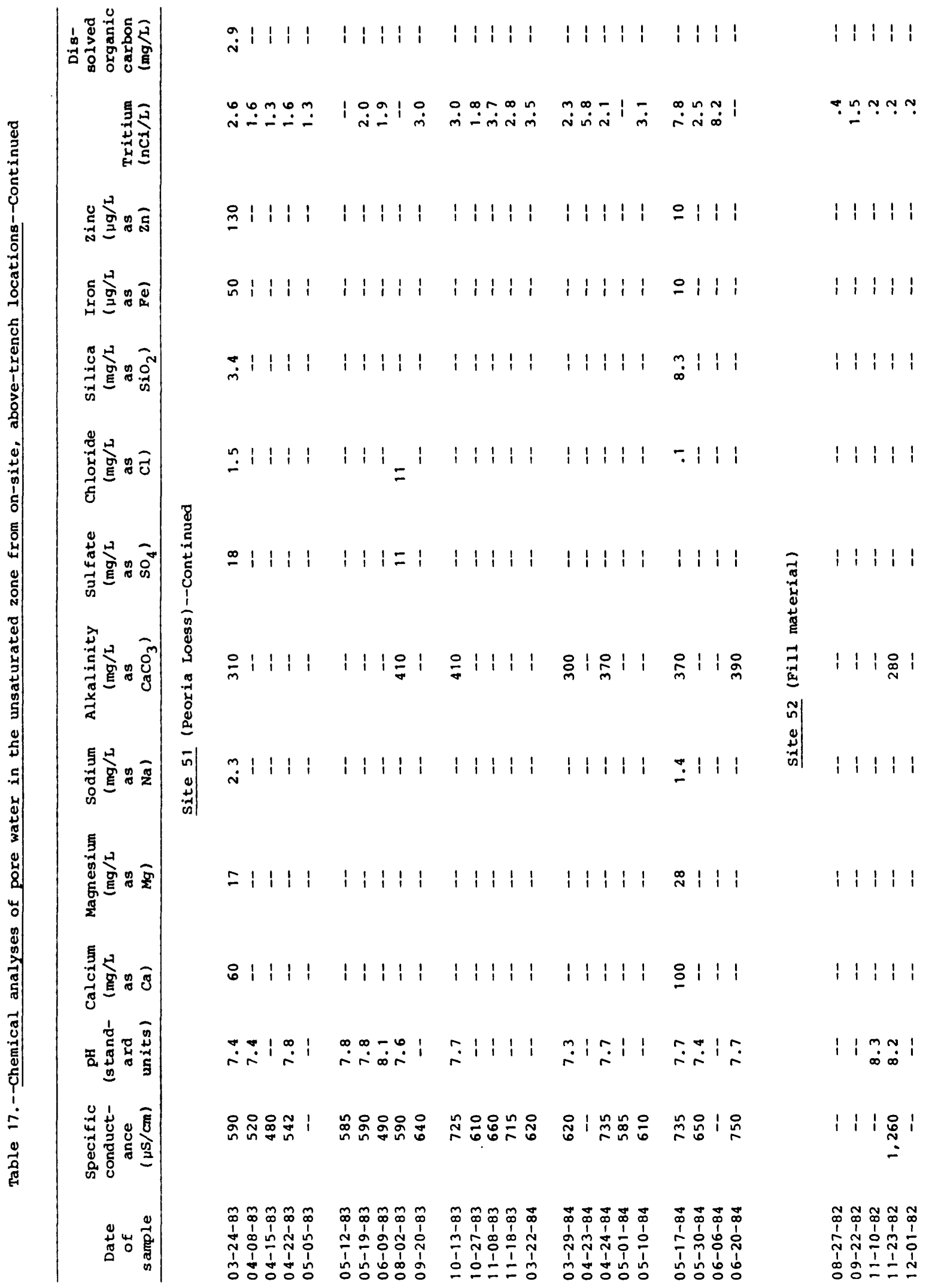




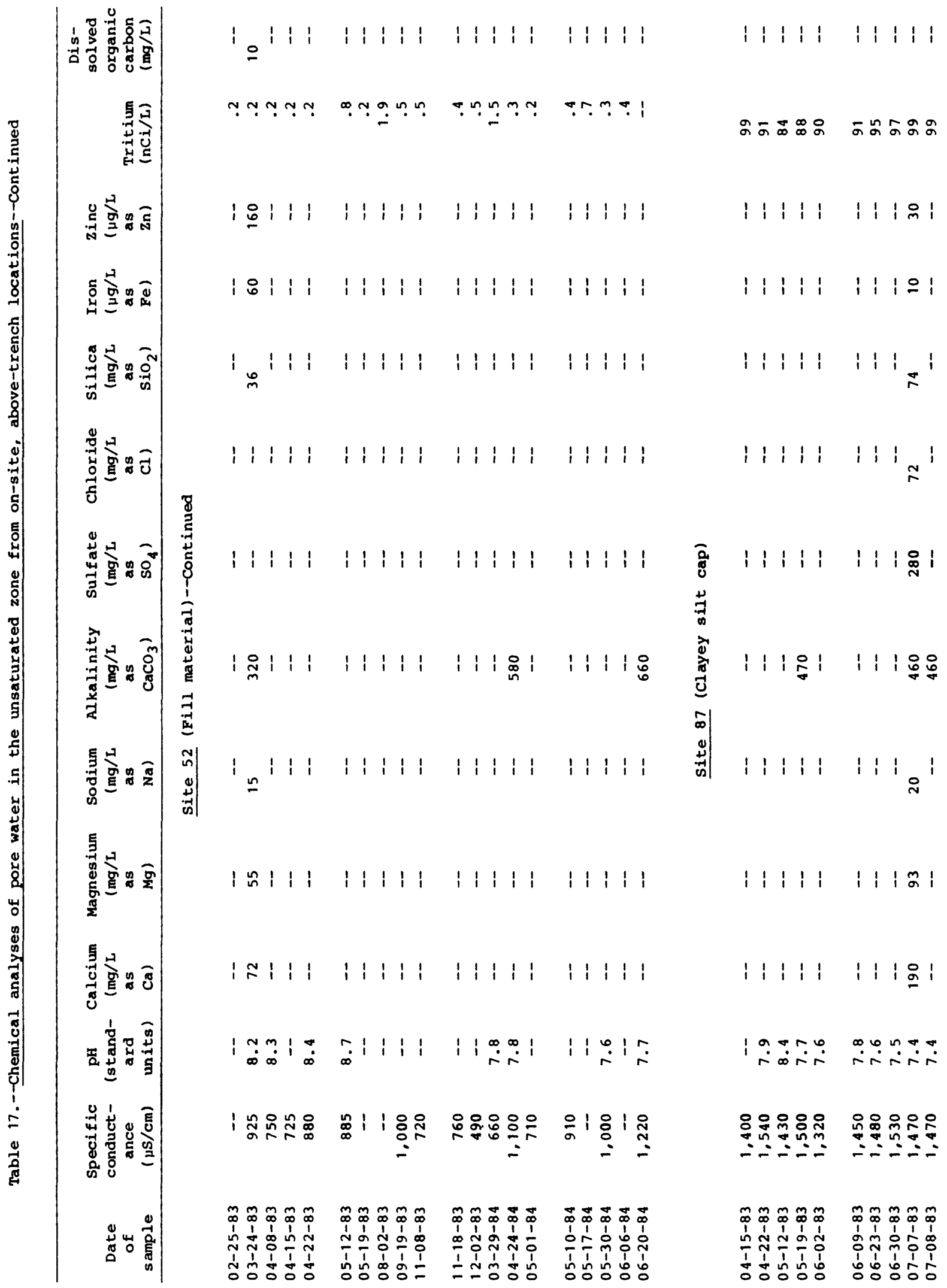




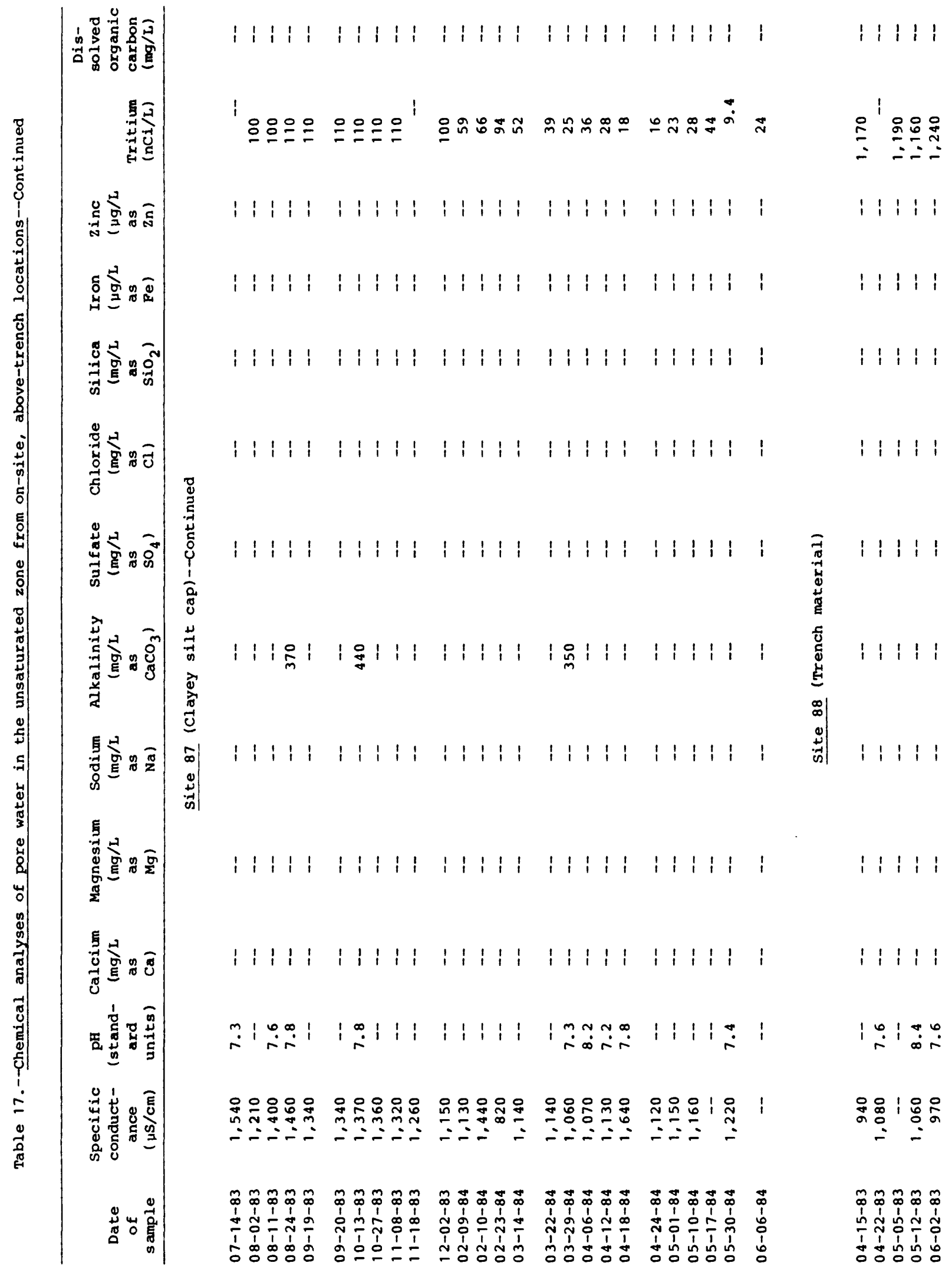




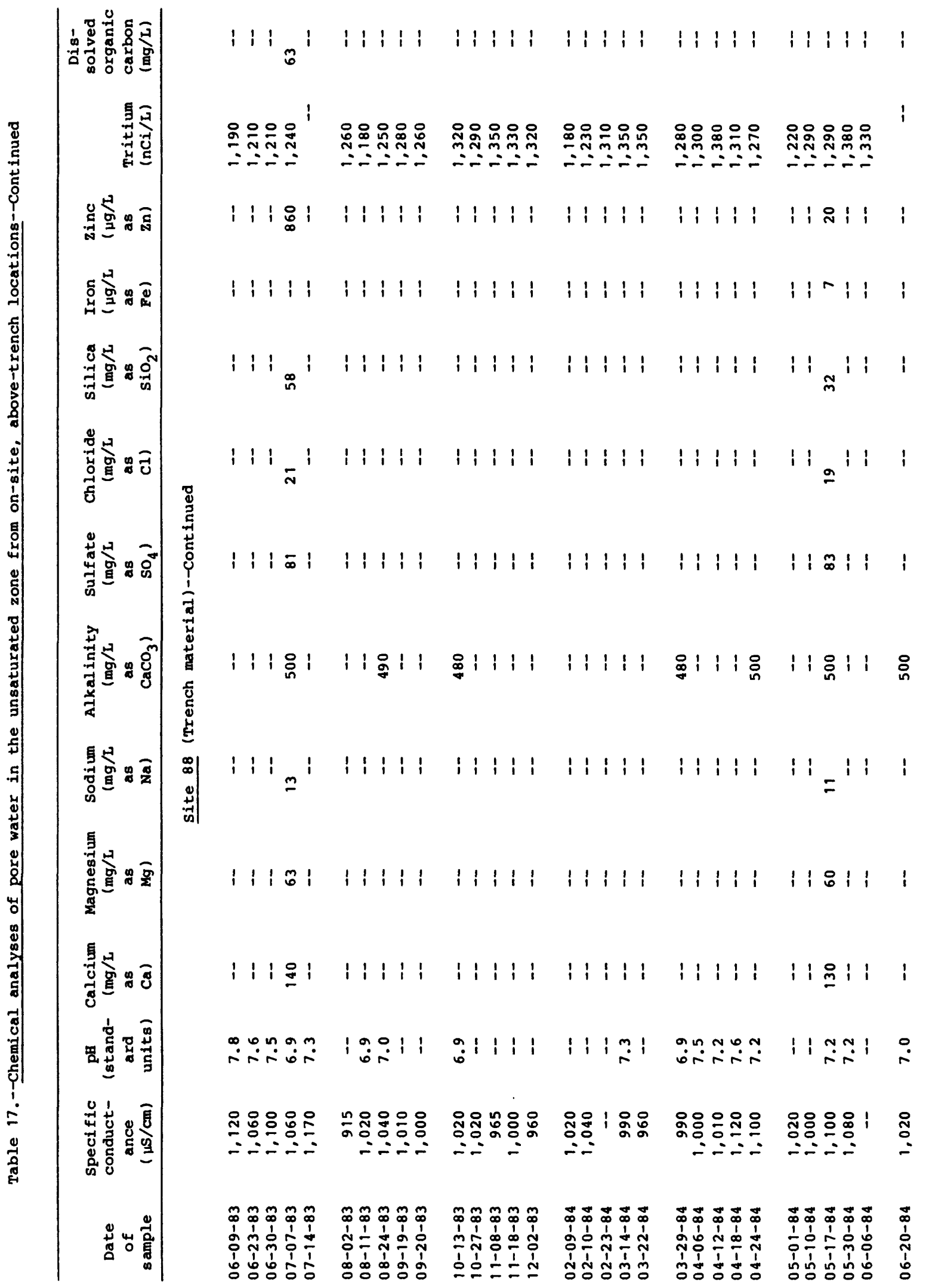




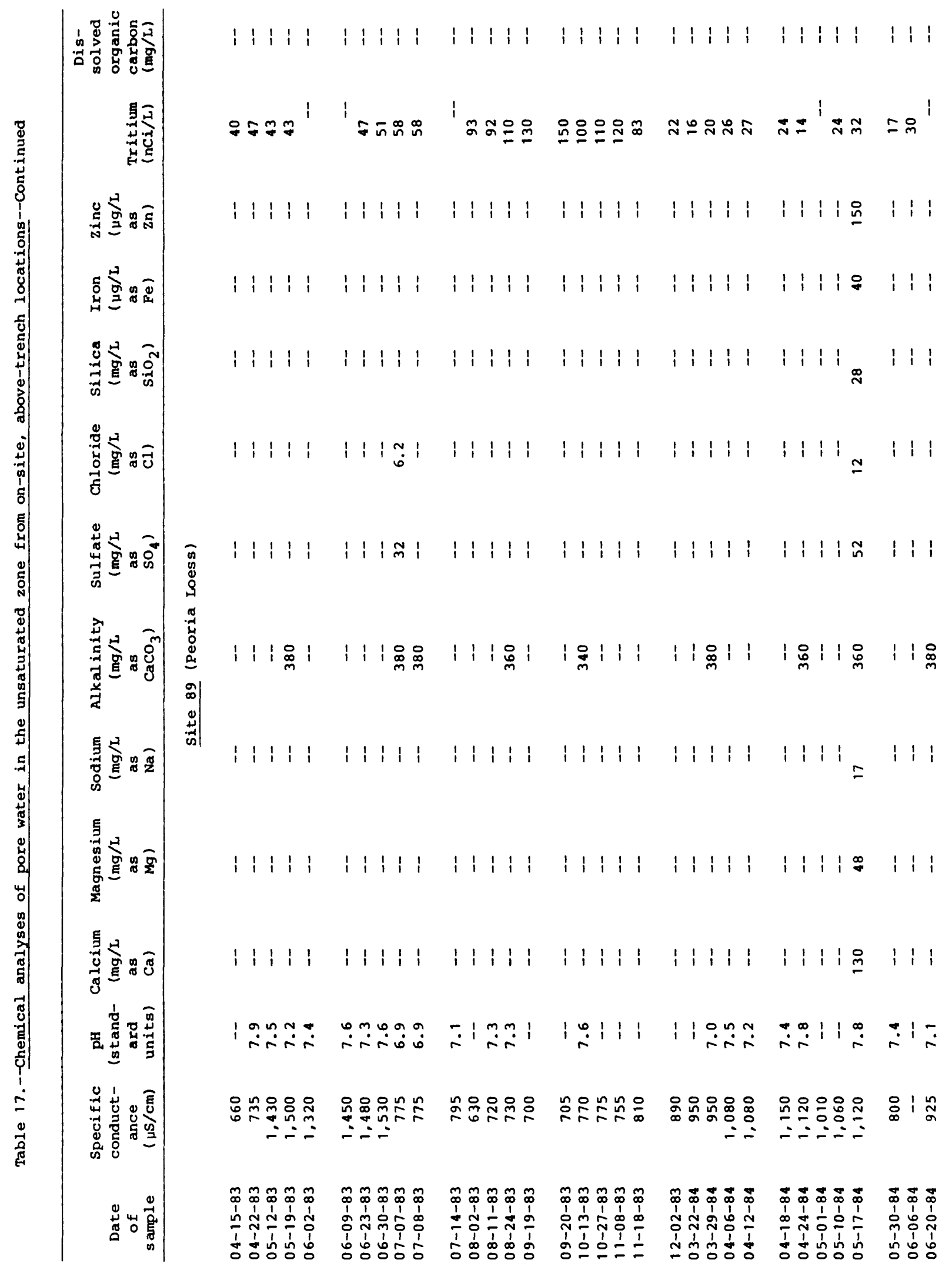




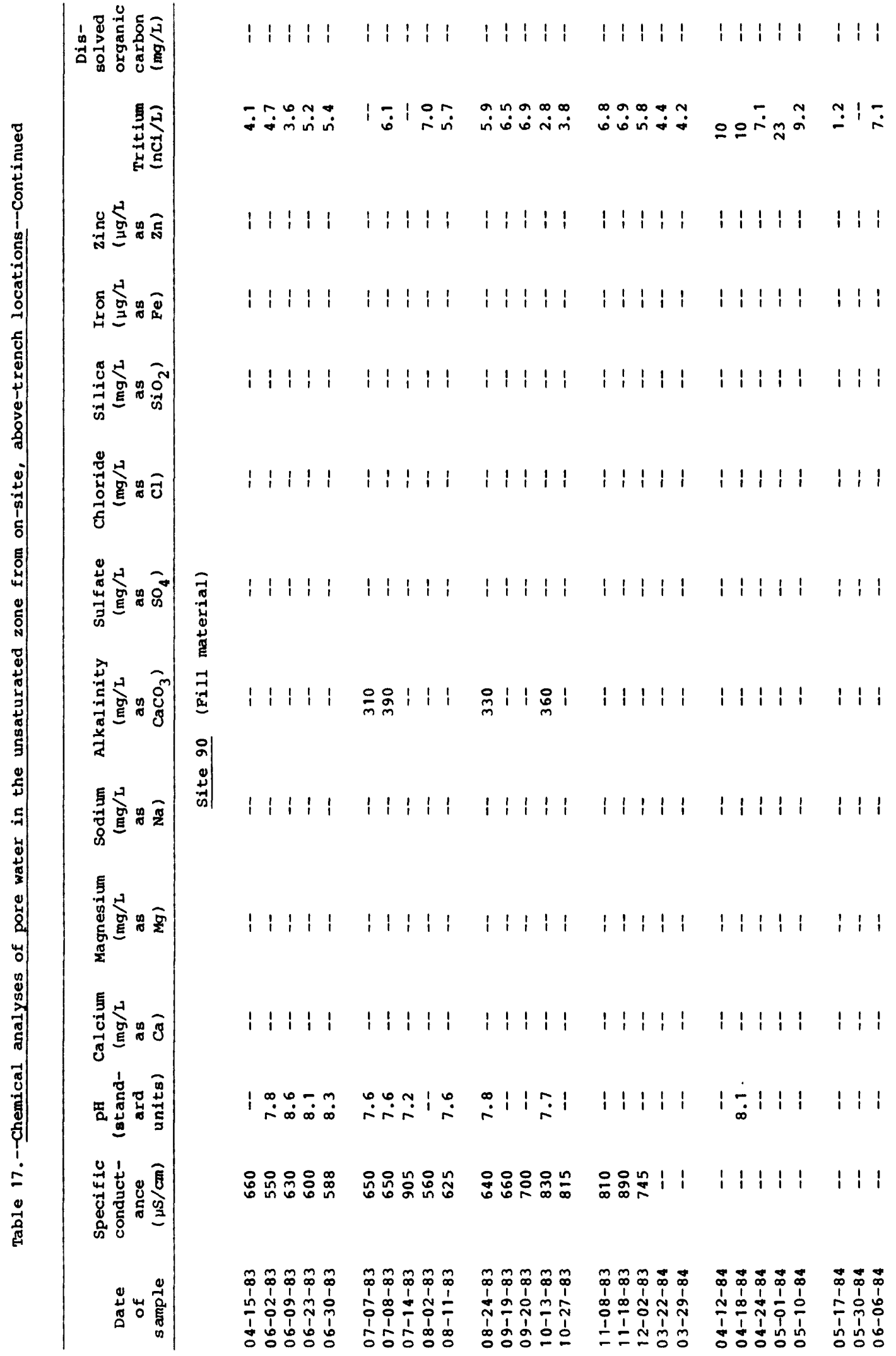




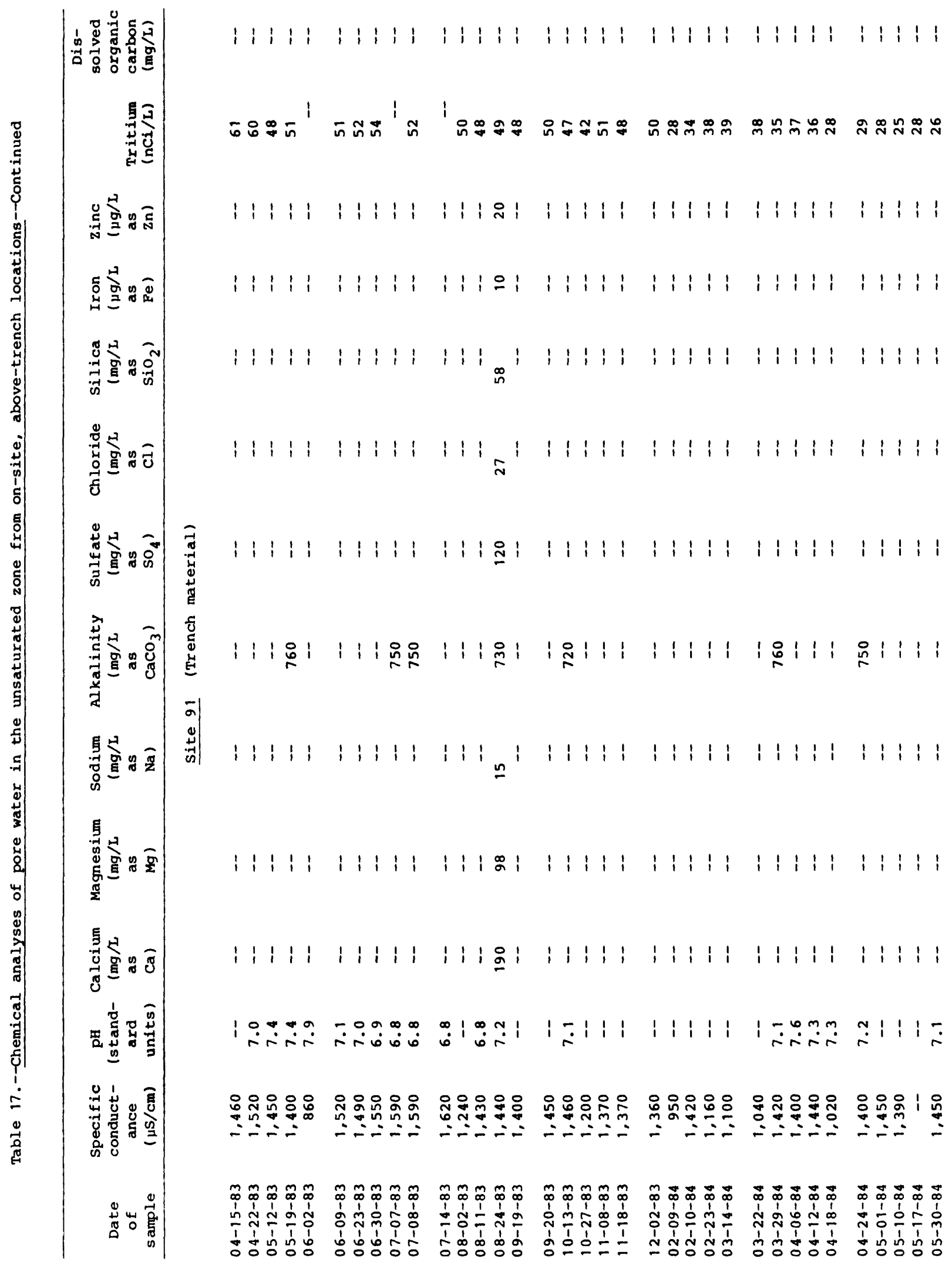




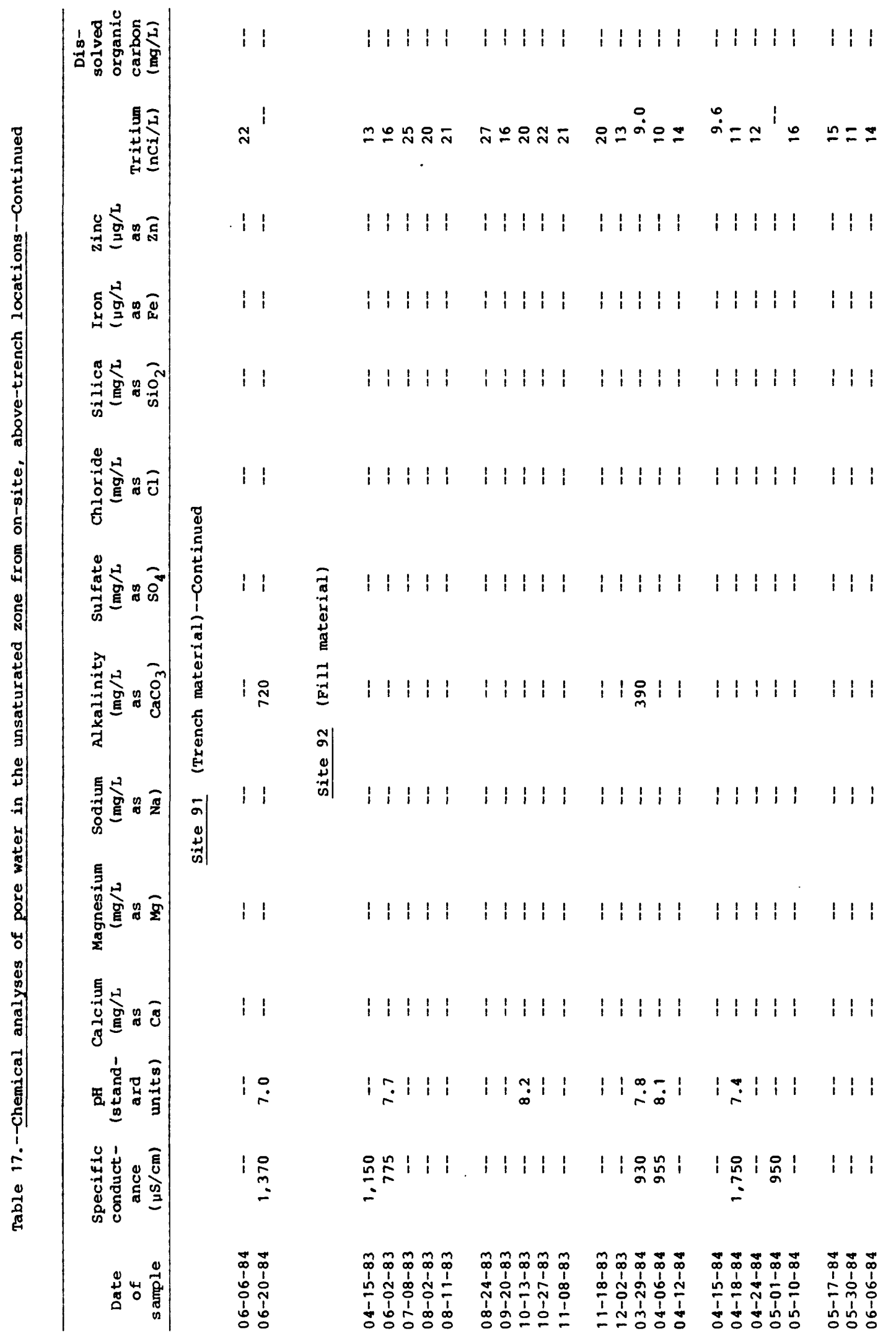




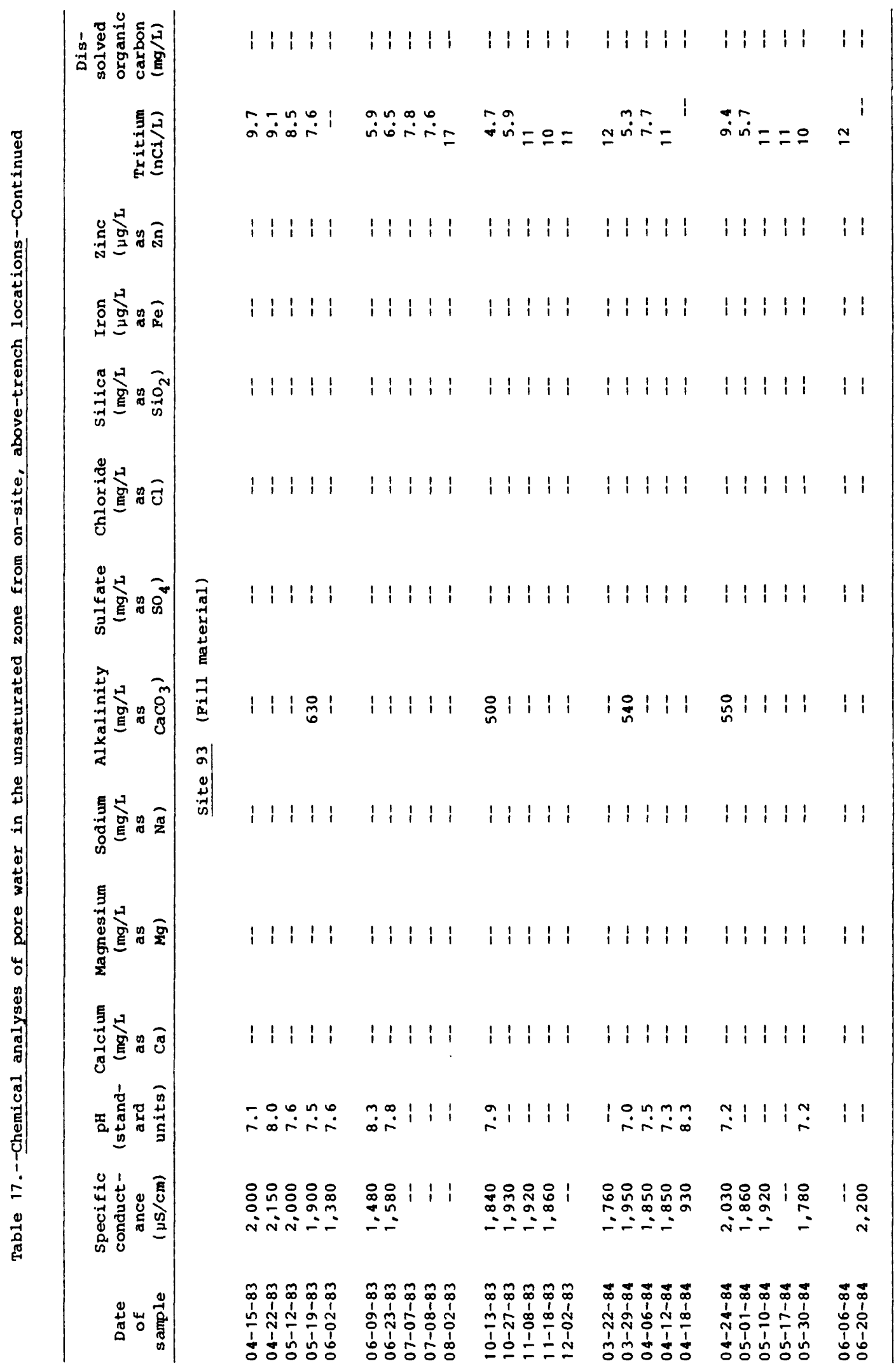




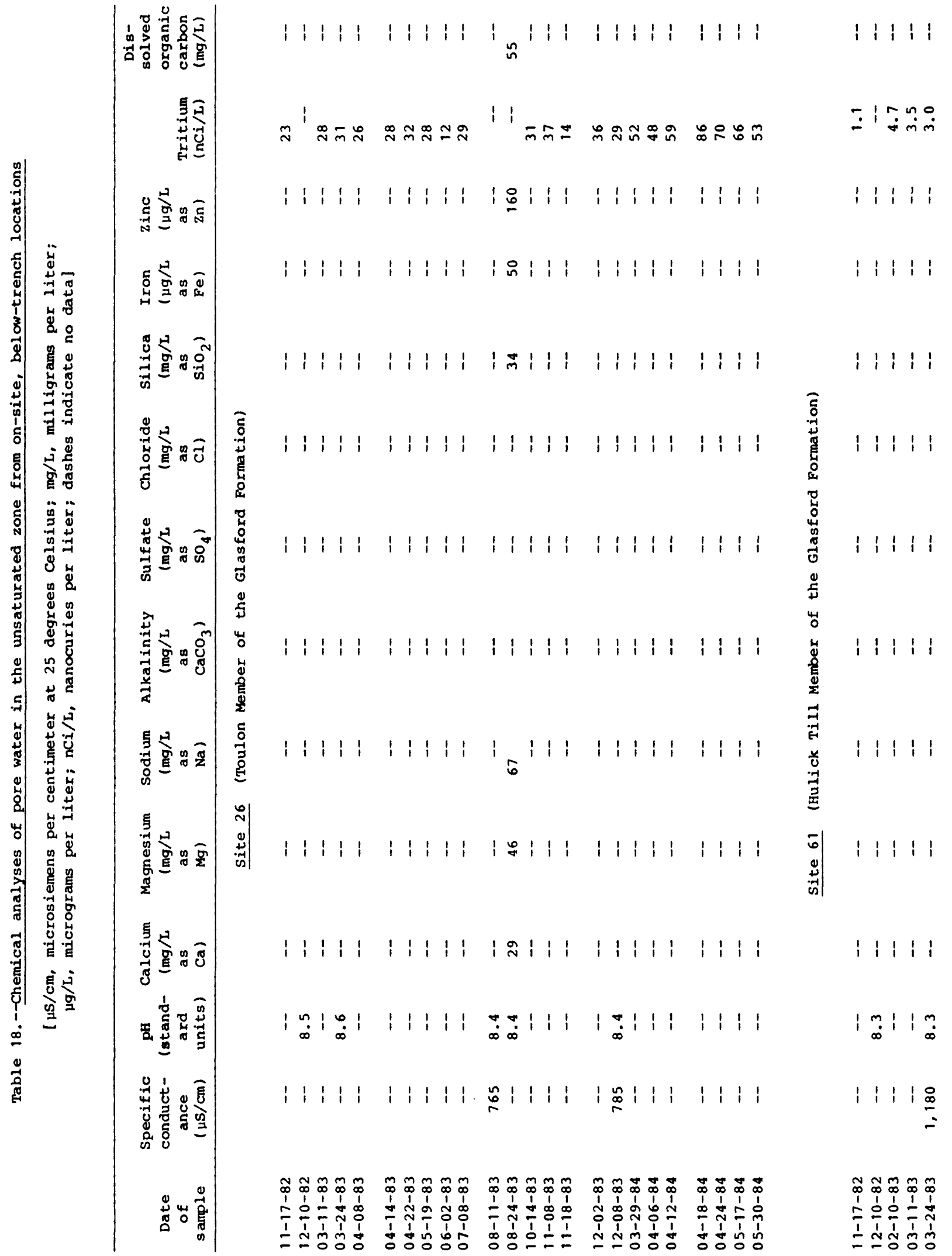




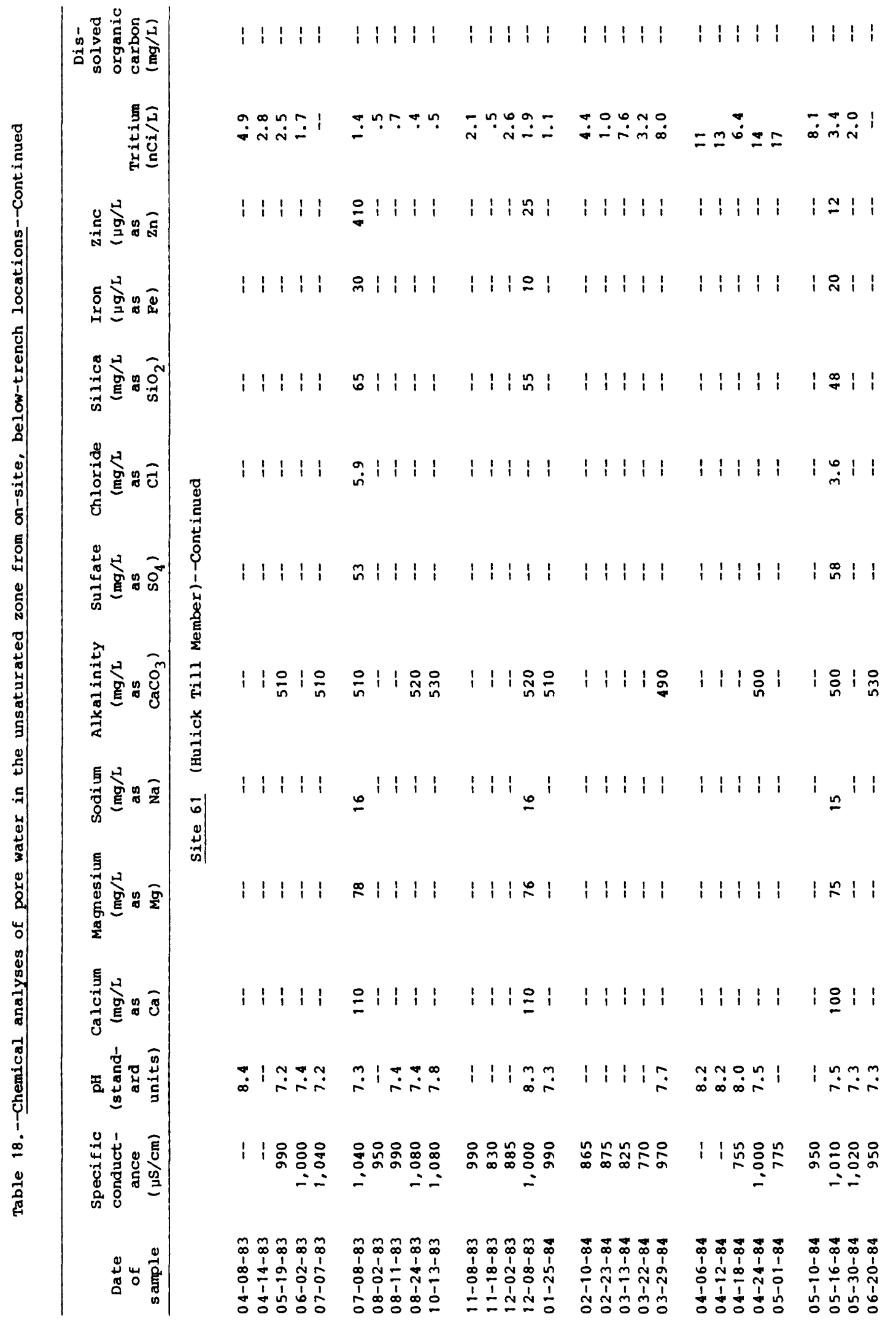




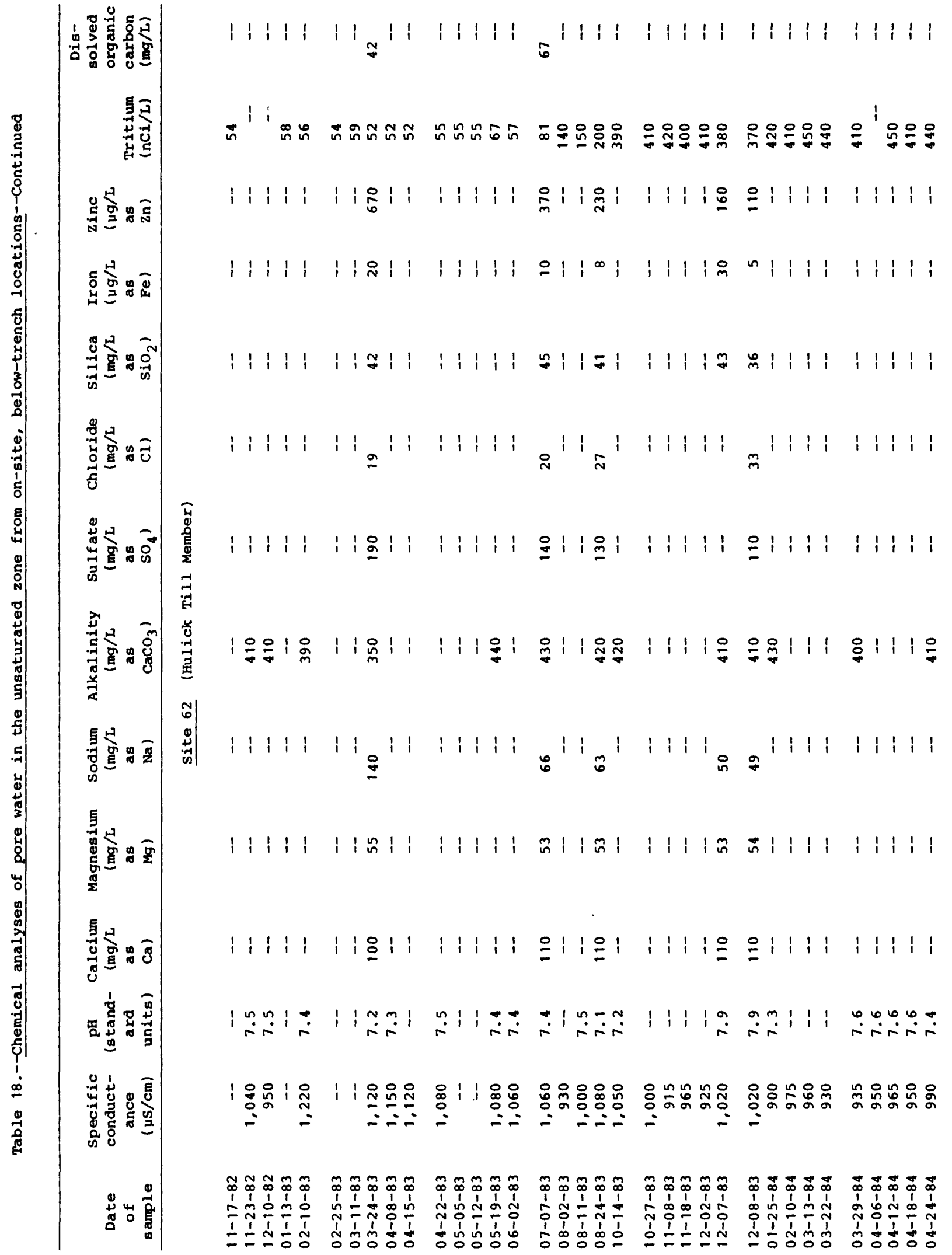




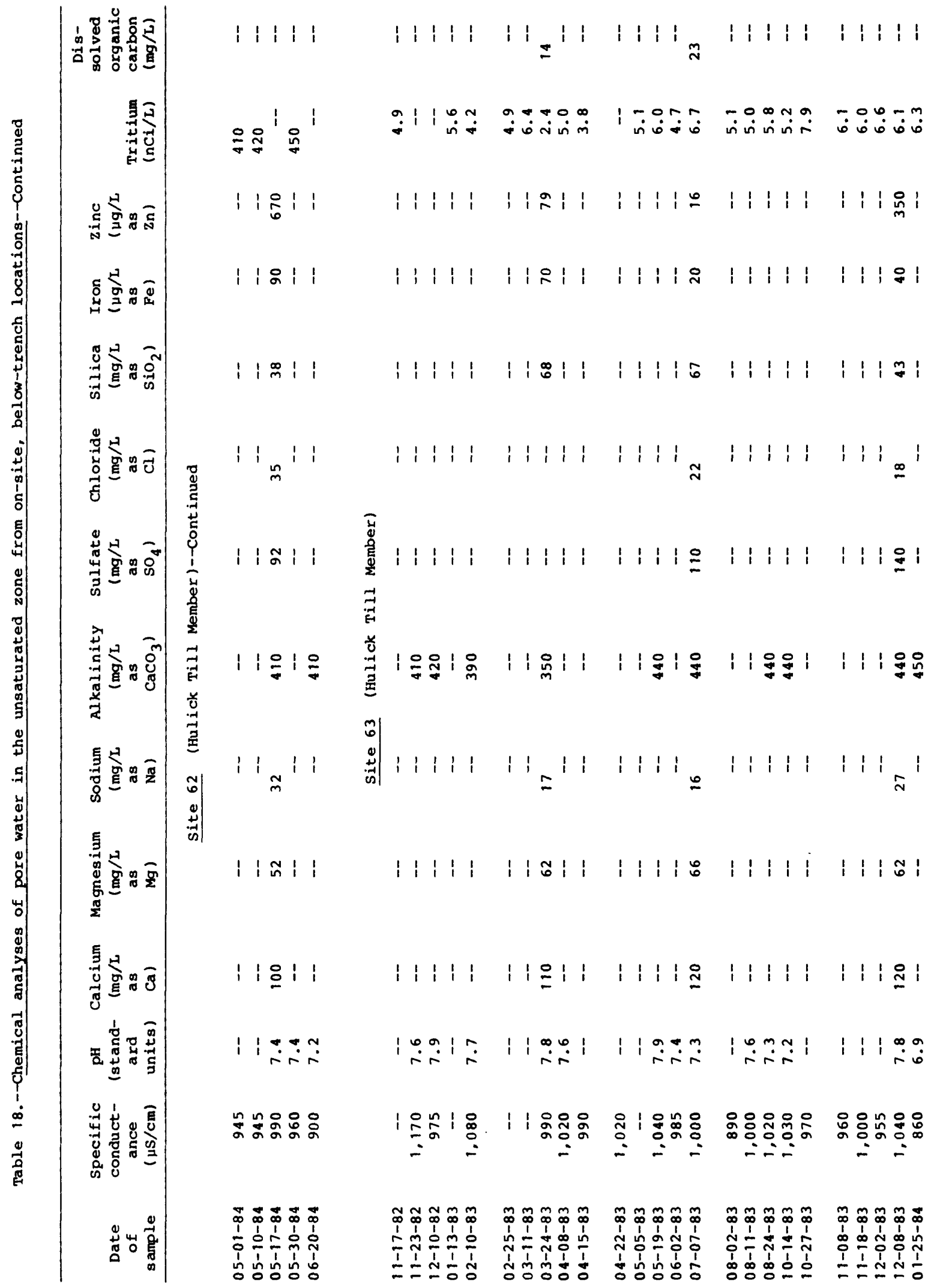




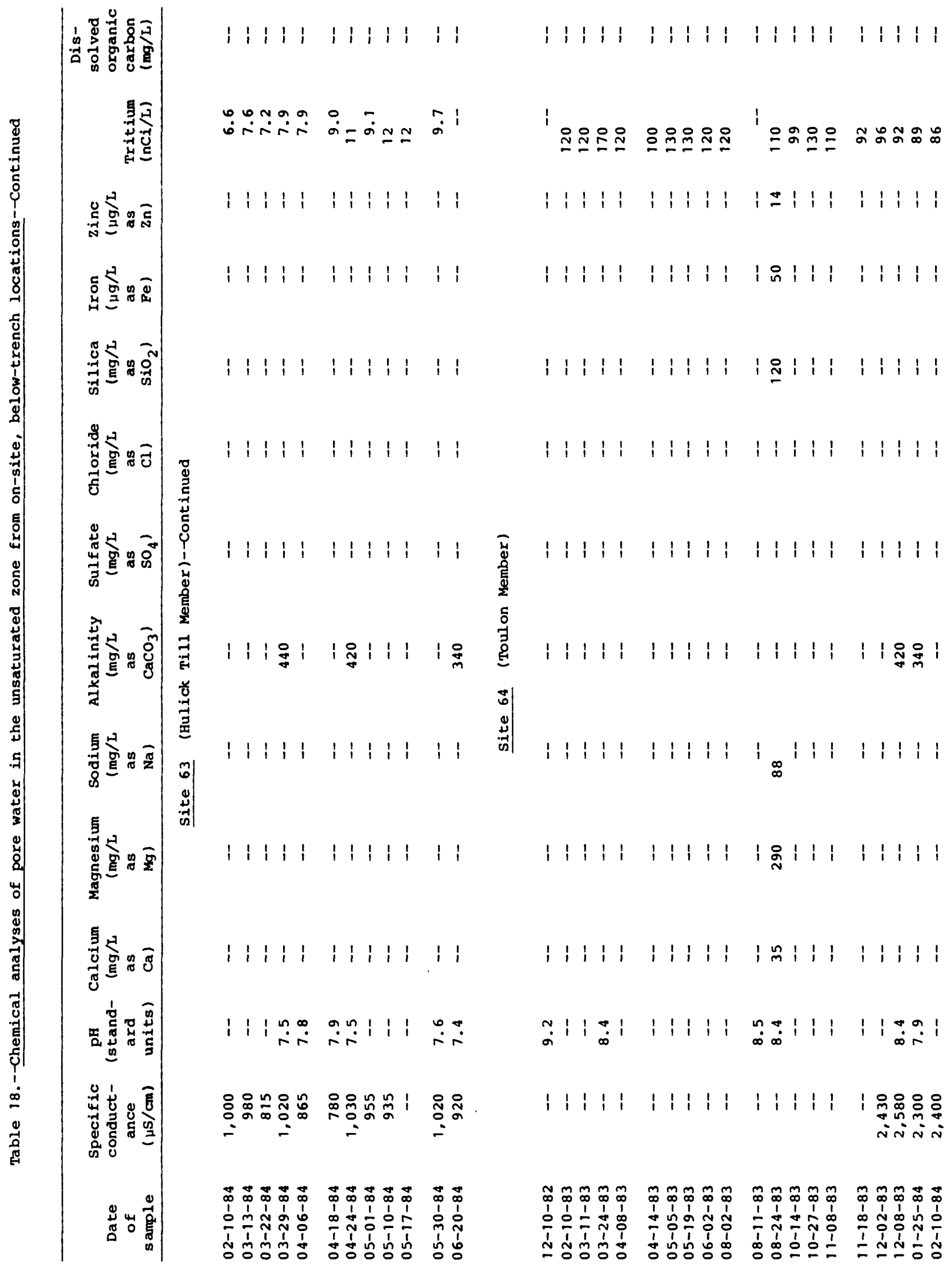




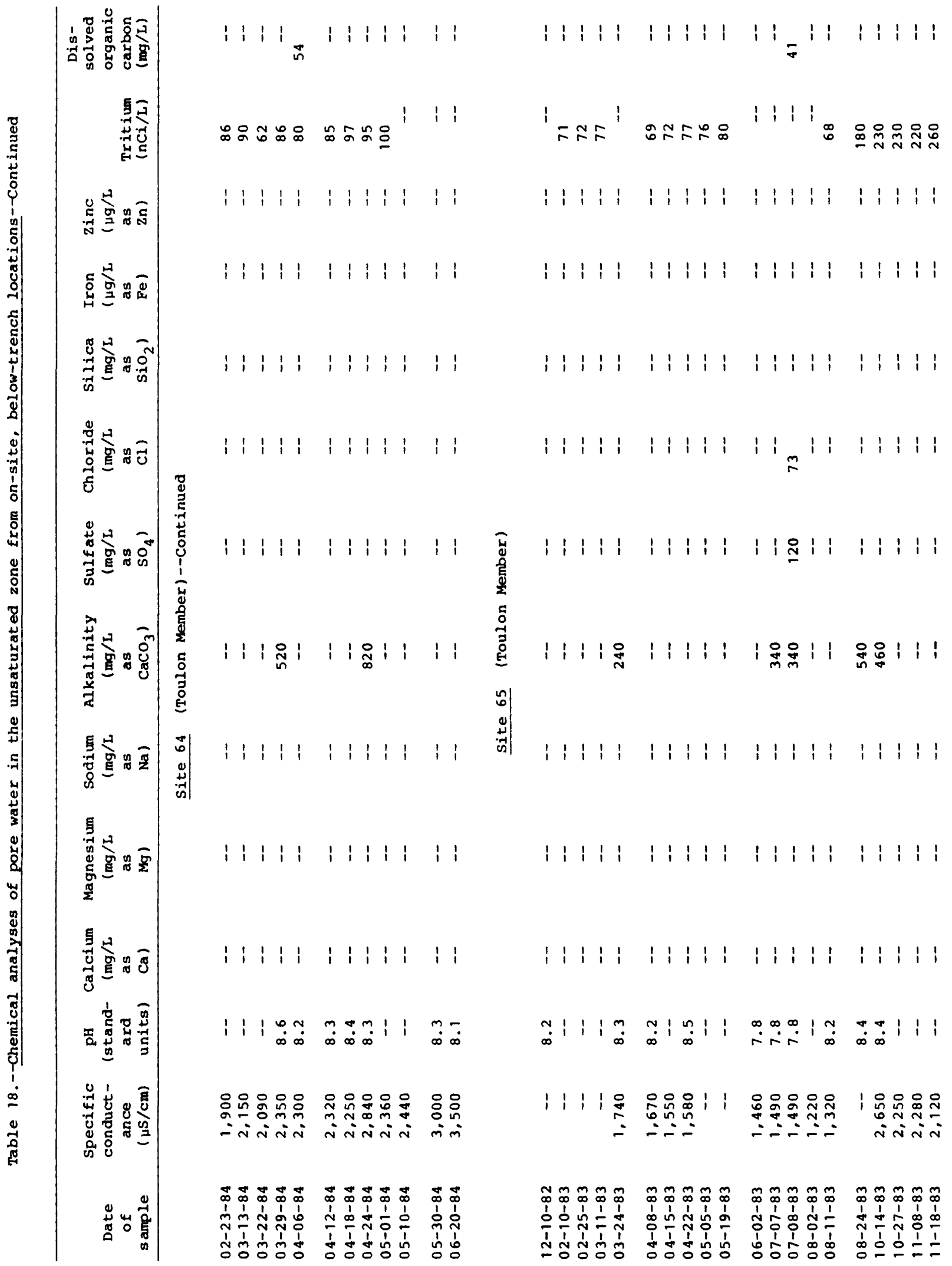




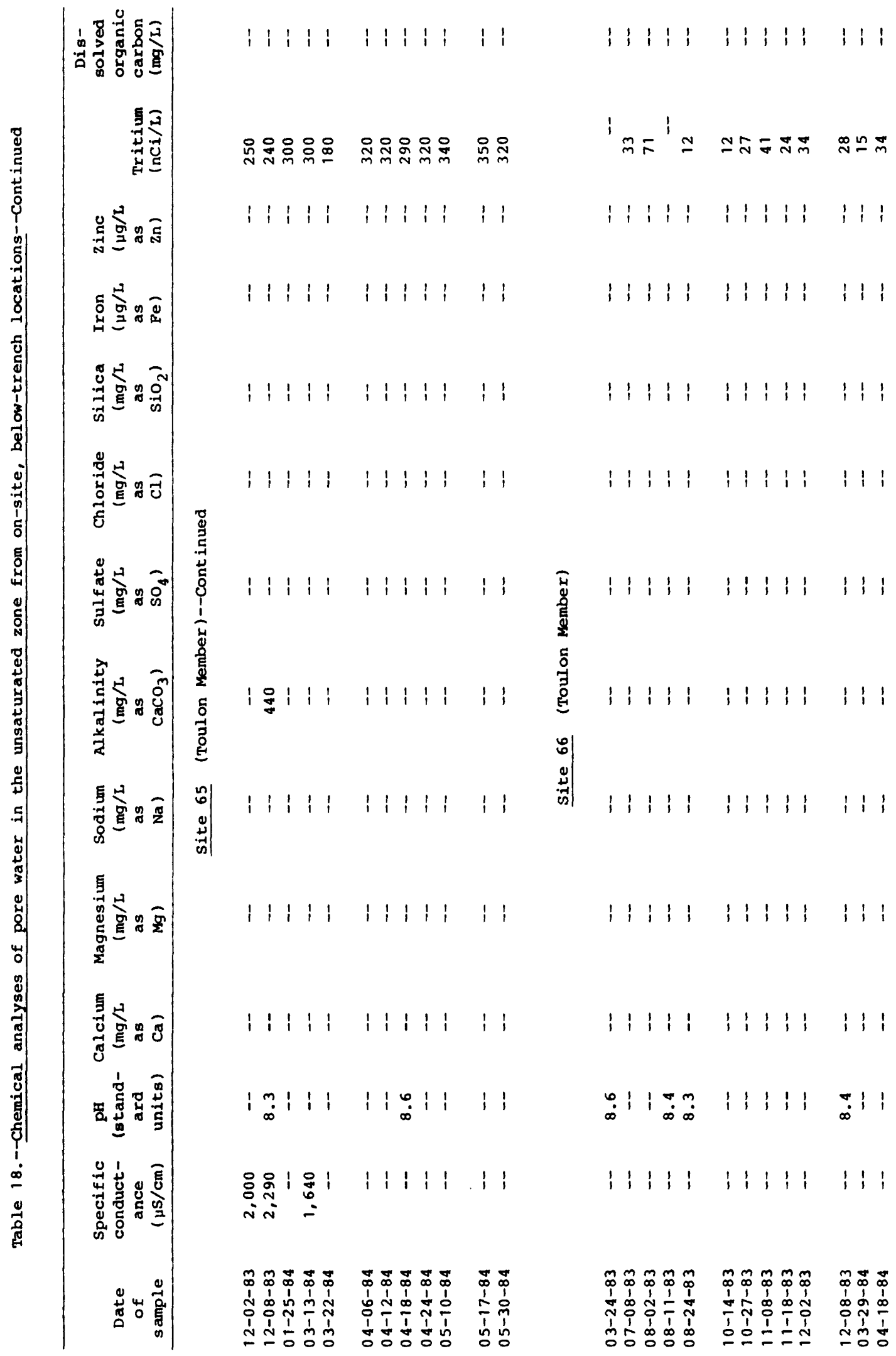




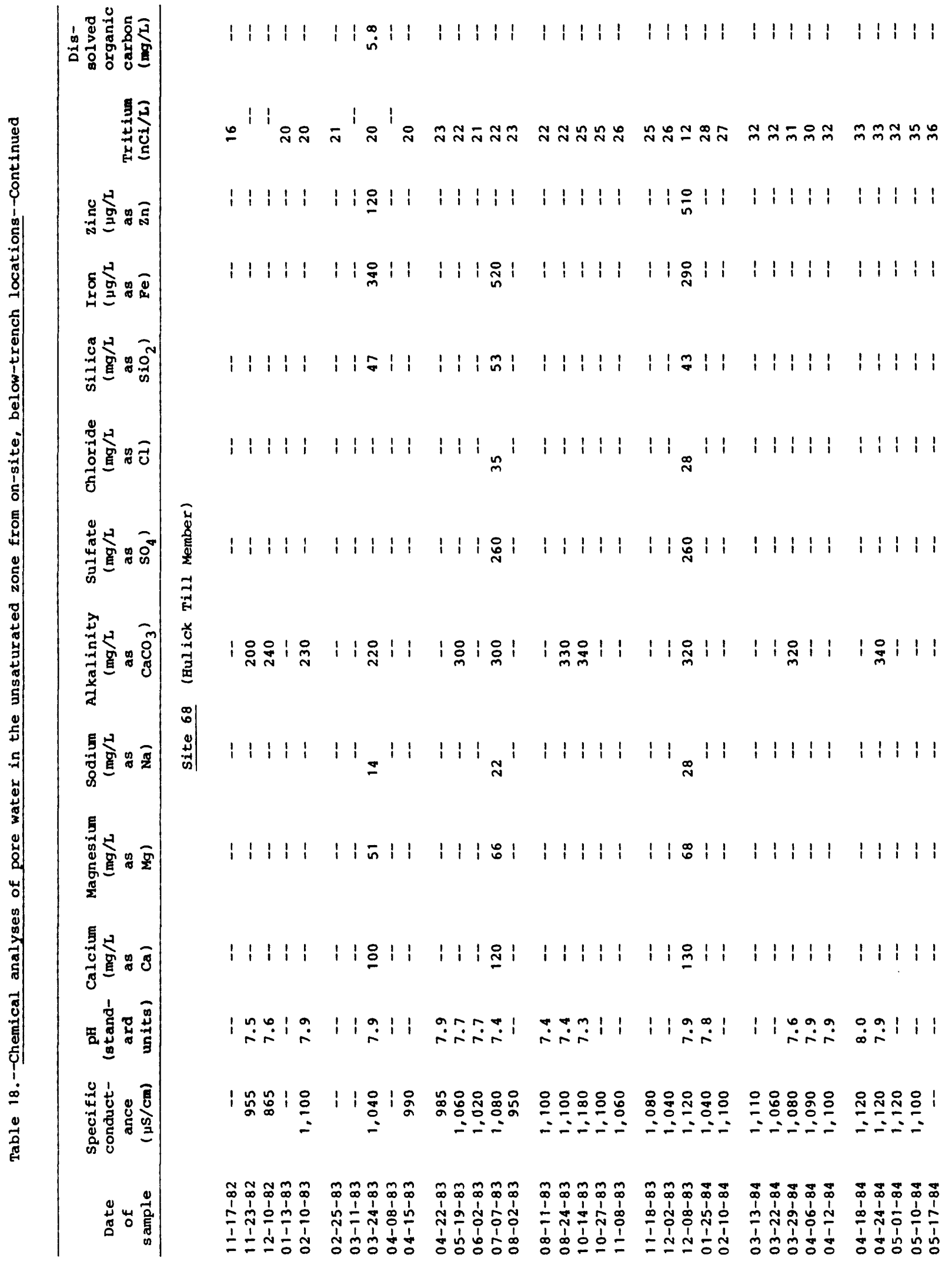




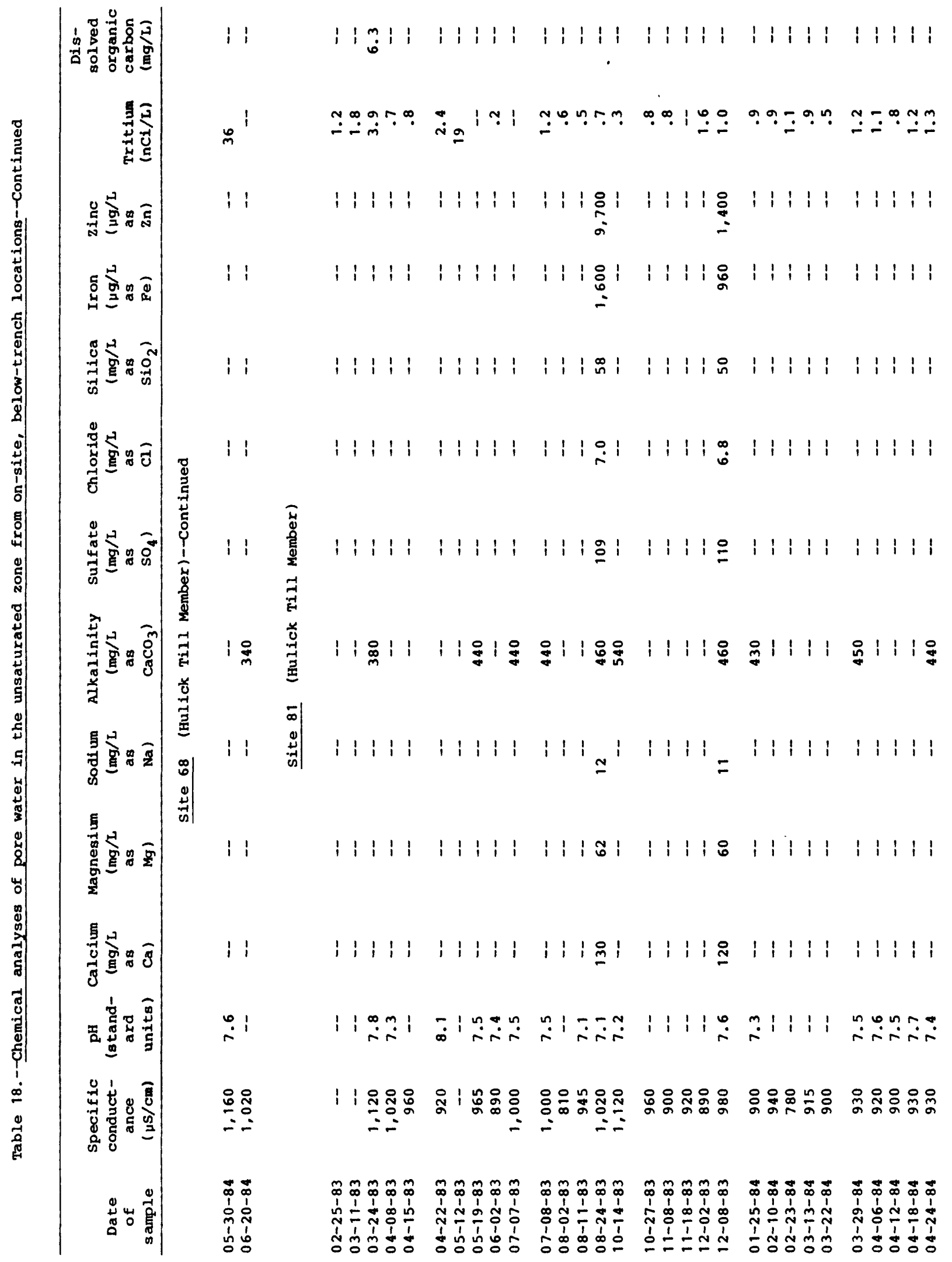




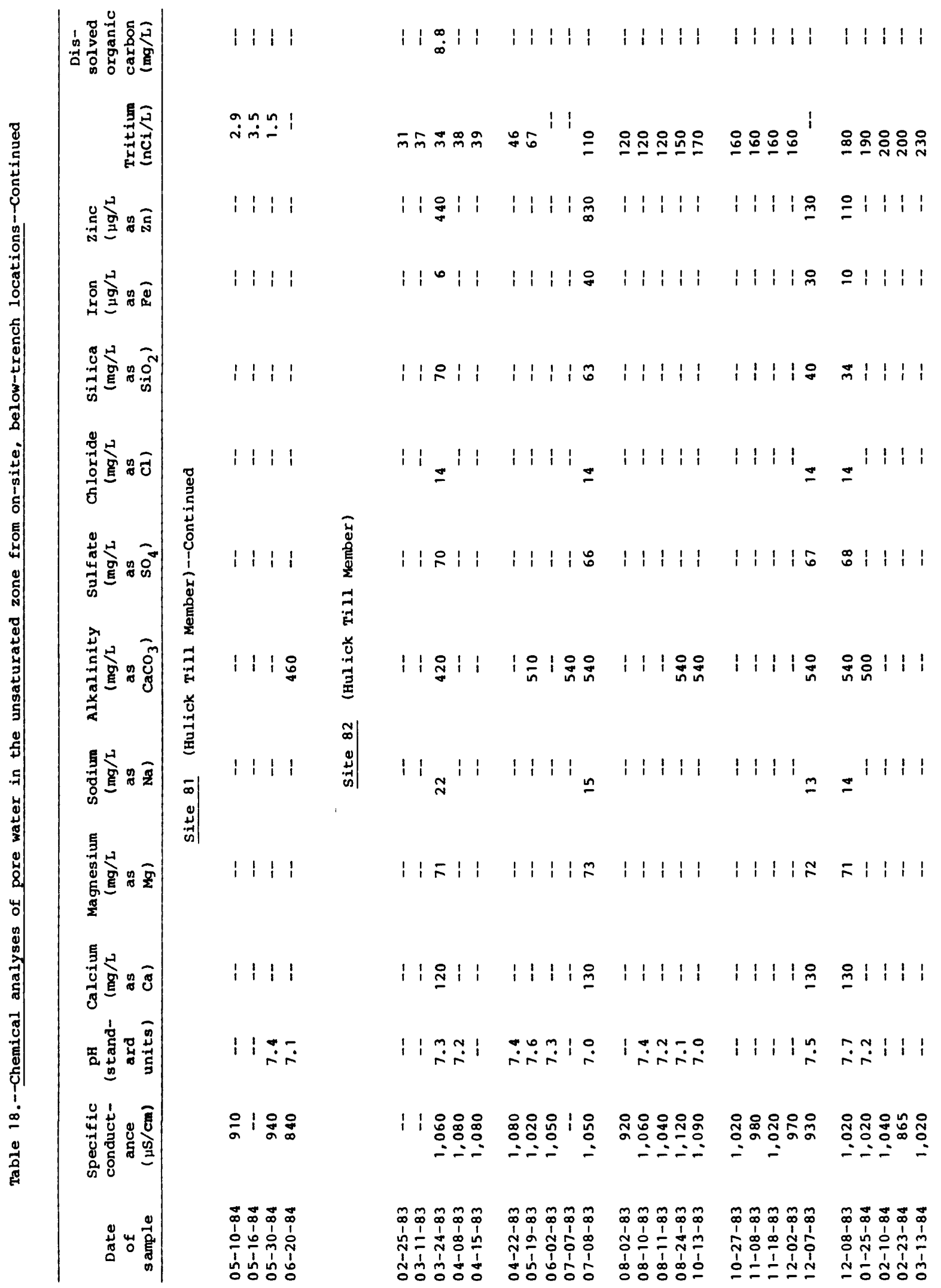




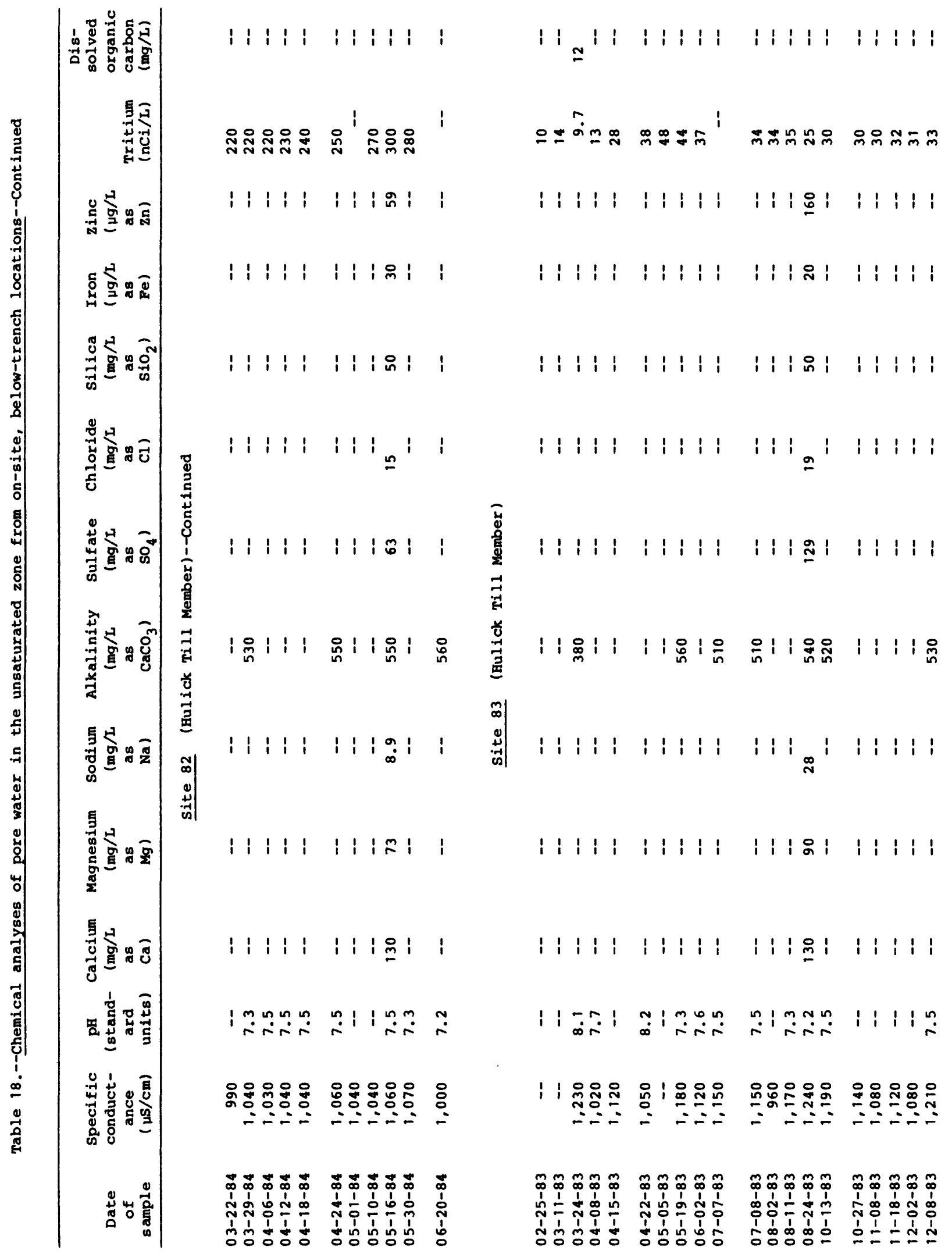




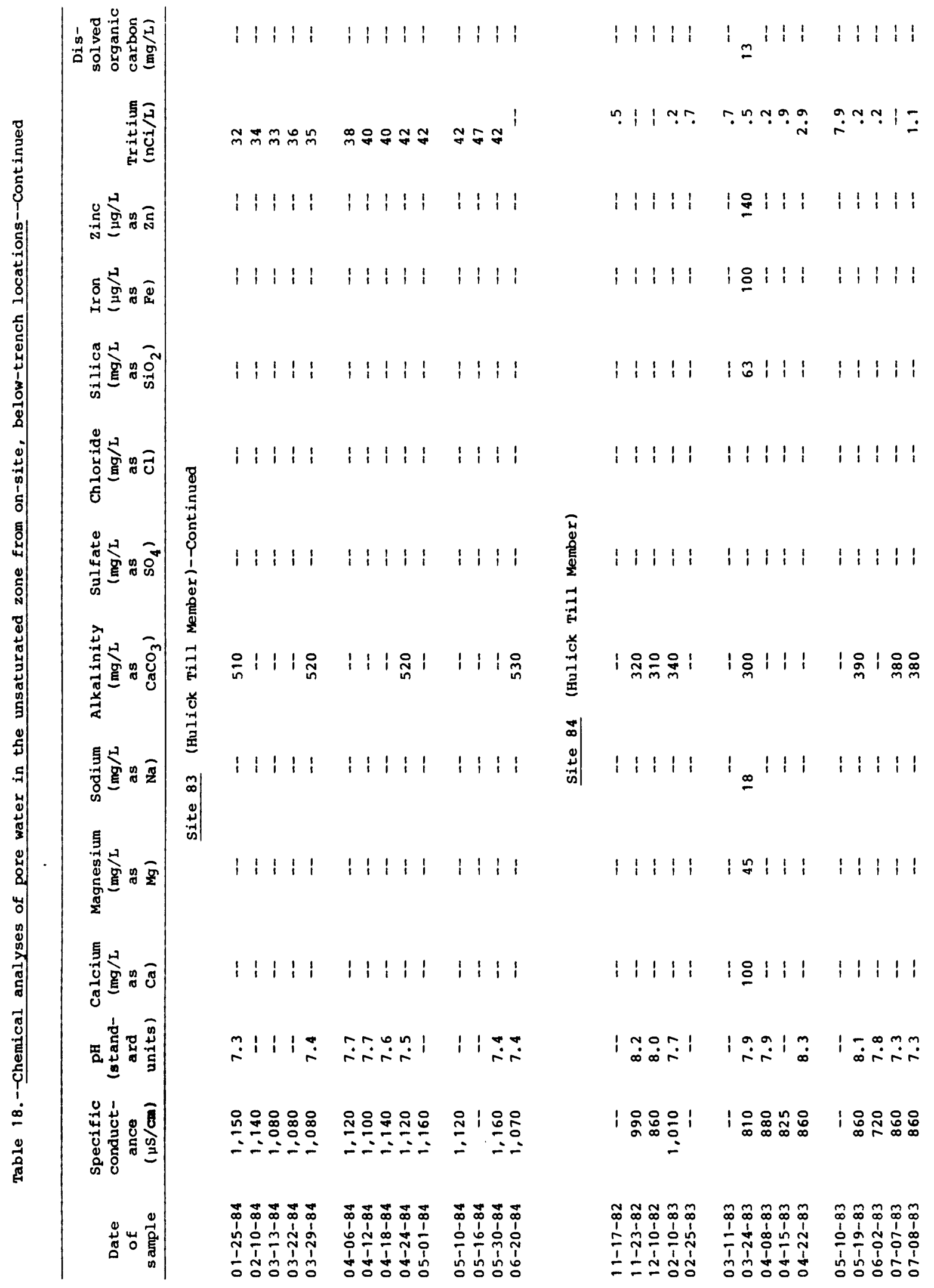




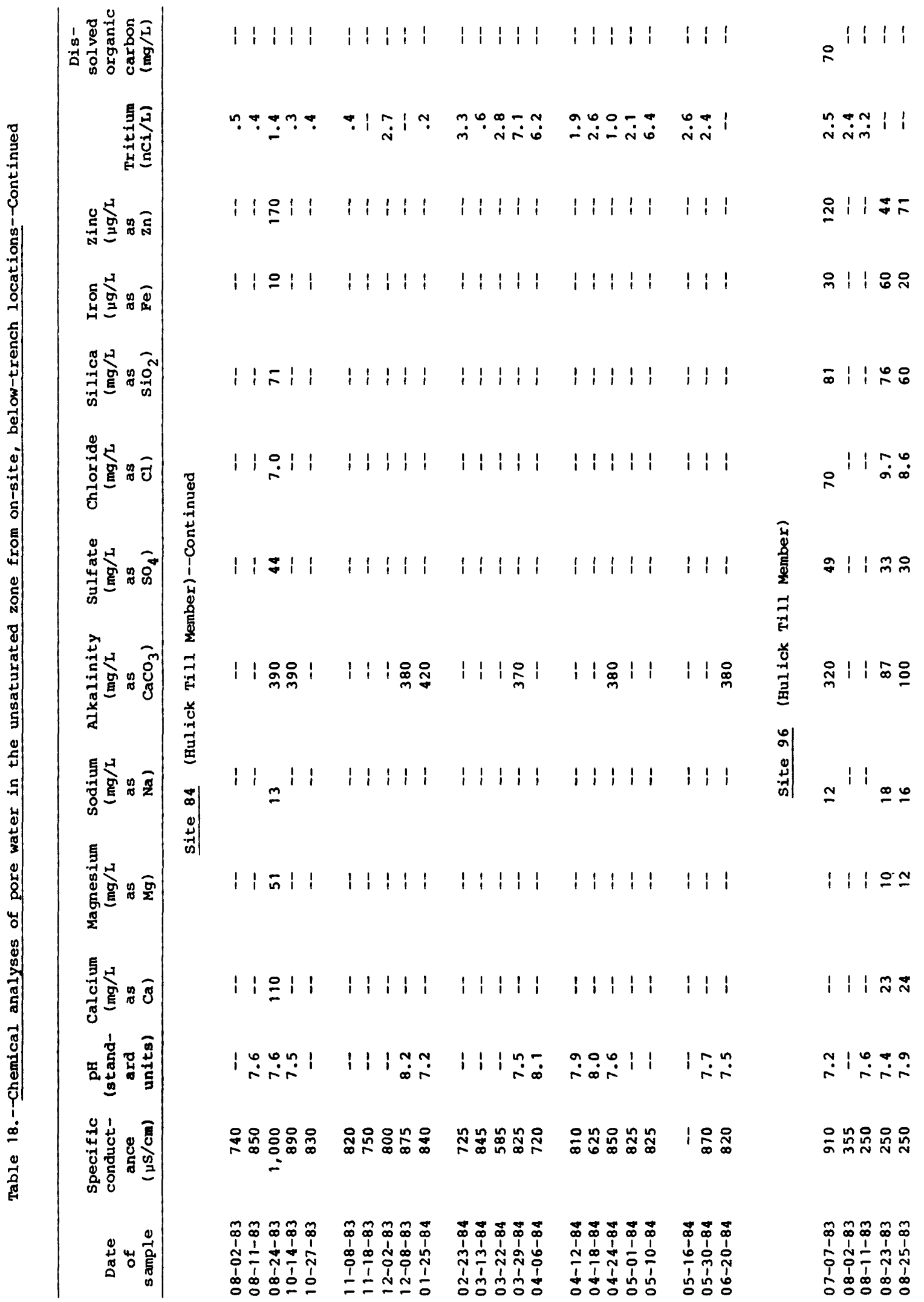




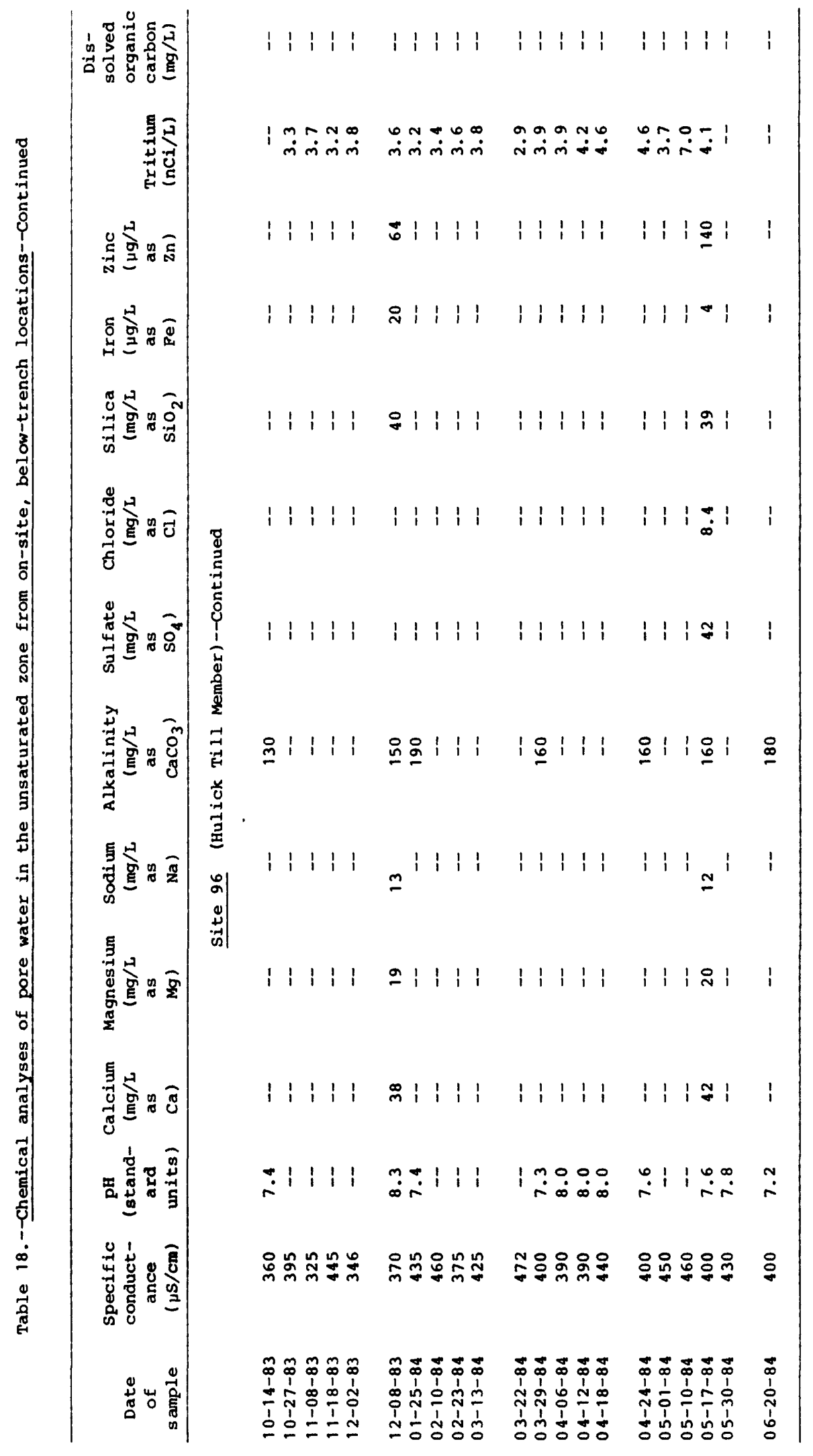


Table 19.--Tritium concentrations in pore water from soil cores

[m, meters; $\mathrm{nCi} / \mathrm{L}$, nanocuries per liter;

dashes indicate no data]

\begin{tabular}{|c|c|c|c|c|}
\hline $\begin{array}{l}\text { Location } \\
\text { of } \\
\text { soil } \\
\text { cores }\end{array}$ & $\begin{array}{l}\text { Geologic } \\
\text { material }\end{array}$ & $\begin{array}{l}\text { Depth } \\
\text { below } \\
\text { land } \\
\text { surface } \\
\text { (m) }\end{array}$ & $\begin{array}{c}\text { Tritium } \\
\text { concentration } \\
(\mathrm{nC} i / L)\end{array}$ & $\begin{array}{c}\text { Initial } \\
\text { tritium } \\
\text { concentration } \\
\text { in lysimeters } \\
(\mathrm{nCi} / \mathrm{L})\end{array}$ \\
\hline \multicolumn{5}{|l|}{ Above trench } \\
\hline Lysimeter 38 & $\begin{array}{l}\text { Fill material } \\
\text { Fill material } \\
\text { Fill material } \\
\text { Clayey silt cap } \\
\text { Peoria Loess } \\
\text { Peoria Loess }\end{array}$ & $\begin{array}{r}0-0.15 \\
.30-.46 \\
.61-.76 \\
.91-1.07 \\
1.22-1.37 \\
1.37-1.57\end{array}$ & $\begin{array}{l}0.8 \\
1.2 \\
5.0 \\
11 \\
16 \\
17\end{array}$ & $\begin{array}{l}-- \\
-- \\
-- \\
19^{--}\end{array}$ \\
\hline Lysimeter 39 & Fill material & $.51-.61$ & 5.0 & 4.8 \\
\hline Lysimeter 40 & $\begin{array}{l}\text { Peoria Loess } \\
\text { Peoria Loess } \\
\text { Peoria Loess }\end{array}$ & $\begin{array}{r}.46-.61 \\
.79-.94 \\
1.09-1.24\end{array}$ & $\begin{array}{l}1.8 \\
1.8 \\
1.9\end{array}$ & $\overline{--}$ \\
\hline Lysimeter 51 & $\begin{array}{l}\text { Peoria Loess } \\
\text { Peoria Loess }\end{array}$ & $\begin{array}{l}.15-.30 \\
.46-.61\end{array}$ & 2.6 & 1.7 \\
\hline Lysimeter 52 & Fill material & $.15-.30$ & 1.1 & .4 \\
\hline Lysimeter 87 & $\begin{array}{l}\text { Fill matieral } \\
\text { Clayey silt cap }\end{array}$ & $\begin{array}{r}.66-.71 \\
1.12-1.17\end{array}$ & $100^{1.2}$ & $94^{--}$ \\
\hline Lysimeter $\mathbf{8 8}$ & Peoria Ioess & $2.26-2.31$ & 1,230 & 1,230 \\
\hline Lysimeter 89 & $\begin{array}{l}\text { Peoria Loess } \\
\text { Peoria Loess }\end{array}$ & $\begin{array}{r}.66-.71 \\
1.37-1.42\end{array}$ & $46^{.2}$ & $42^{--}$ \\
\hline Lysimeter 91 & $\begin{array}{l}\text { Fill material } \\
\text { Fill material } \\
\text { Peoria Loess }\end{array}$ & $\begin{array}{l}.66-.71 \\
1.30-1.35 \\
2.16\end{array}$ & $\begin{array}{r}1.2 \\
30\end{array}$ & $64^{--}$ \\
\hline Lysimeter 93 & Fill material & $.41-.46$ & 2.1 & 10 \\
\hline
\end{tabular}


Table 19.--Tritium concentrations in pore water from soil cores--Continued

\begin{tabular}{cccc}
\hline & & Distance & Initial \\
Location & from & & $\begin{array}{c}\text { tritium } \\
\text { of }\end{array}$ \\
soil & tunnel & Tritium & $\begin{array}{c}\text { concentration } \\
\text { cores }\end{array}$ \\
\hline
\end{tabular}

Below trench

\begin{tabular}{|c|c|c|c|c|c|c|}
\hline \multirow{4}{*}{\multicolumn{2}{|c|}{ Lysimeter 111}} & $\begin{array}{l}\text { Toulon } \\
\text { Toulon }\end{array}$ & $\begin{array}{l}\text { Member }{ }^{2} \\
\text { Member }\end{array}$ & $\begin{array}{r}0.05-0.20 \\
.36-.51\end{array}$ & $\begin{array}{l}16 \\
18\end{array}$ & -- \\
\hline & & Toulon & Member & $.60-.81$ & 22 & -- \\
\hline & & $\begin{array}{l}\text { Toul on } \\
\text { Toul on }\end{array}$ & $\begin{array}{l}\text { Member } \\
\text { Member }\end{array}$ & $\begin{array}{r}.91-1.07 \\
1.22-1.37\end{array}$ & $\begin{array}{l}26 \\
51\end{array}$ & -- \\
\hline & & $\begin{array}{l}\text { Toulon } \\
\text { Hulick }\end{array}$ & $\begin{array}{l}\text { Member } \\
\text { Till Member }{ }^{2}\end{array}$ & $\begin{array}{l}1.52-1.68 \\
1.83-1.98\end{array}$ & $\begin{array}{l}70 \\
36\end{array}$ & $70^{--}$ \\
\hline \multirow[t]{2}{*}{ Lys imeter } & 61 & $\begin{array}{l}\text { Hul ick } \\
\text { Hul ick }\end{array}$ & $\begin{array}{l}\text { Till Member } \\
\text { Till Member }\end{array}$ & $\begin{array}{l}.25-.41 \\
.64-.76\end{array}$ & $\begin{array}{l}3.4 \\
1.2\end{array}$ & -- \\
\hline & & Hul ick & Till Member & $1.27-1.42$ & .8 & 1.1 \\
\hline Lysimeter & 62 & $\begin{array}{l}\text { Hulick } \\
\text { Hulick } \\
\text { Hulick }\end{array}$ & $\begin{array}{ll}\text { Till } & \text { Member } \\
\text { Till } & \text { Member } \\
\text { Till } & \text { Member }\end{array}$ & $\begin{array}{r}.05-.18 \\
.46-.61 \\
1.02-1.17\end{array}$ & $\begin{array}{l}17 \\
17 \\
33\end{array}$ & $54^{--}$ \\
\hline Lysimeter & 63 & $\begin{array}{l}\text { Hul ick } \\
\text { Hul ick }\end{array}$ & $\begin{array}{l}\text { Till Member } \\
\text { Till Member }\end{array}$ & $\begin{array}{l}.08-.23 \\
.97-1.12\end{array}$ & $\begin{array}{l}9.5 \\
4.2\end{array}$ & 4.9 \\
\hline Lysimeter & 64 & $\begin{array}{l}\text { Toulon } \\
\text { Toulon } \\
\text { Toulon }\end{array}$ & $\begin{array}{l}\text { Member } \\
\text { Member } \\
\text { Member }\end{array}$ & $\begin{array}{r}0-.05 \\
.69-.74 \\
1.42-1.47\end{array}$ & $\begin{array}{r}89 \\
76 \\
100\end{array}$ & $120^{--}$ \\
\hline Lys imeter & 65 & $\begin{array}{l}\text { Toulon } \\
\text { Toulon } \\
\text { Toulon }\end{array}$ & $\begin{array}{l}\text { Member } \\
\text { Member } \\
\text { Member }\end{array}$ & $\begin{array}{r}.05-.10 \\
.66-.71 \\
1.32-1.37\end{array}$ & $\begin{array}{l}27 \\
47 \\
64\end{array}$ & $70^{--}$ \\
\hline Lysimeter & 66 & $\begin{array}{l}\text { Toulon } \\
\text { Toulon }\end{array}$ & $\begin{array}{l}\text { Member } \\
\text { Member }\end{array}$ & $\begin{array}{l}.05-.10 \\
.66-.74\end{array}$ & $\begin{array}{l}14 \\
14\end{array}$ & $35^{--}$ \\
\hline Lys imeter & 68 & $\begin{array}{l}\text { Toulon } \\
\text { Hulick }\end{array}$ & $\begin{array}{l}\text { Member } \\
\text { Till Member }\end{array}$ & $\begin{array}{l}.41-.46 \\
.64-.69\end{array}$ & $\begin{array}{l}28 \\
26\end{array}$ & $20^{--}$ \\
\hline Lys imeter & 81 & $\begin{array}{l}\text { Hulick } \\
\text { Hulick } \\
\text { Hulick }\end{array}$ & $\begin{array}{ll}\text { Till } & \text { Member } \\
\text { Till } & \text { Member } \\
\text { Till Member }\end{array}$ & $\begin{array}{r}.05-.20 \\
.51-.76 \\
1.22-1.37\end{array}$ & $\begin{array}{r}2.4 \\
1.0 \\
.4\end{array}$ & $2 .--$ \\
\hline Lysimeter & 82 & $\begin{array}{l}\text { Hulick } \\
\text { Hulick } \\
\text { Hulick }\end{array}$ & $\begin{array}{l}\text { Till Member } \\
\text { Till Member } \\
\text { Till Member }\end{array}$ & $\begin{array}{r}.30-.56 \\
.71-.97 \\
1.34-1.50\end{array}$ & $\begin{array}{l}21 \\
12 \\
7.7\end{array}$ & $31^{--}$ \\
\hline
\end{tabular}


Table 19.--Tritium concentrations in pore water from soil cores--Continued

\begin{tabular}{|c|c|c|c|c|}
\hline $\begin{array}{l}\text { Location } \\
\text { of } \\
\text { soil } \\
\text { cores }\end{array}$ & $\begin{array}{l}\text { Geologic } \\
\text { material }\end{array}$ & $\begin{array}{l}\text { Distance } \\
\text { from } \\
\text { tunnel } \\
\text { liner } \\
\text { (m) }\end{array}$ & $\begin{array}{c}\text { Tritium } \\
\text { concentration } \\
(\mathrm{nCi} / \mathrm{L})\end{array}$ & $\begin{array}{c}\text { Initial } \\
\text { tritium } \\
\text { concentration } \\
\text { in lysimeters } \\
(\mathrm{nCi} / \mathrm{L})\end{array}$ \\
\hline Lysimeter 83 & $\begin{array}{l}\text { Hulick Till Member } \\
\text { Hulick Till Member }\end{array}$ & $\begin{array}{r}0.05-0.20 \\
.64-.79\end{array}$ & $\begin{array}{l}5.0 \\
8.3\end{array}$ & $10^{--}$ \\
\hline \multirow[t]{10}{*}{ Piezometer 271} & $\begin{array}{l}\text { Toul on Member } \\
\text { Toulon Member }\end{array}$ & $\begin{array}{l}.20-.28 \\
.28-.36\end{array}$ & $\begin{array}{l}26 \\
33\end{array}$ & -- \\
\hline & $\begin{array}{l}\text { Toulon Member } \\
\text { Toulon Member } \\
\text { Toulon Member }\end{array}$ & $\begin{array}{l}.36-.43 \\
.43-.51 \\
.51-.58\end{array}$ & $\begin{array}{l}29 \\
24 \\
22\end{array}$ & $\begin{array}{l}-- \\
-- \\
--\end{array}$ \\
\hline & $\begin{array}{l}\text { Toulon Member } \\
\text { Toulon Member }\end{array}$ & $\begin{array}{r}.66-.74 \\
1.45-1.52\end{array}$ & $\begin{array}{l}42 \\
53\end{array}$ & -- \\
\hline & Toulon Member & $1.52-1.60$ & 64 & -- \\
\hline & Toulon Member & $1.60-1.68$ & 83 & -- \\
\hline & Toulon Member & $1.68-1.75$ & 97 & -- \\
\hline & $\begin{array}{l}\text { Toulon Member } \\
\text { Toul on Member }\end{array}$ & $\begin{array}{l}1.75-1.83 \\
2.90-2.97\end{array}$ & $\begin{array}{r}99 \\
110\end{array}$ & $\begin{array}{l}-- \\
--\end{array}$ \\
\hline & Toulon Member & $2.97-3.05$ & 140 & -- \\
\hline & $\begin{array}{l}\text { Toulon Member } \\
\text { Toulon Member }\end{array}$ & $\begin{array}{l}3.05-3.12 \\
3.12-3.20\end{array}$ & $\begin{array}{l}140 \\
140\end{array}$ & -- \\
\hline & $\begin{array}{l}\text { Toulon Member } \\
\text { Weathered shale }\end{array}$ & $\begin{array}{l}3.20-3.28 \\
3.43-3.84\end{array}$ & $\begin{array}{r}170 \\
53\end{array}$ & $\begin{array}{l}-- \\
--\end{array}$ \\
\hline
\end{tabular}

${ }^{1}$ Location shown in figure 6 ; the few number of water samples obtained from the instrument location precluded its additional use in the study.

2 of the Glasford Formation. 


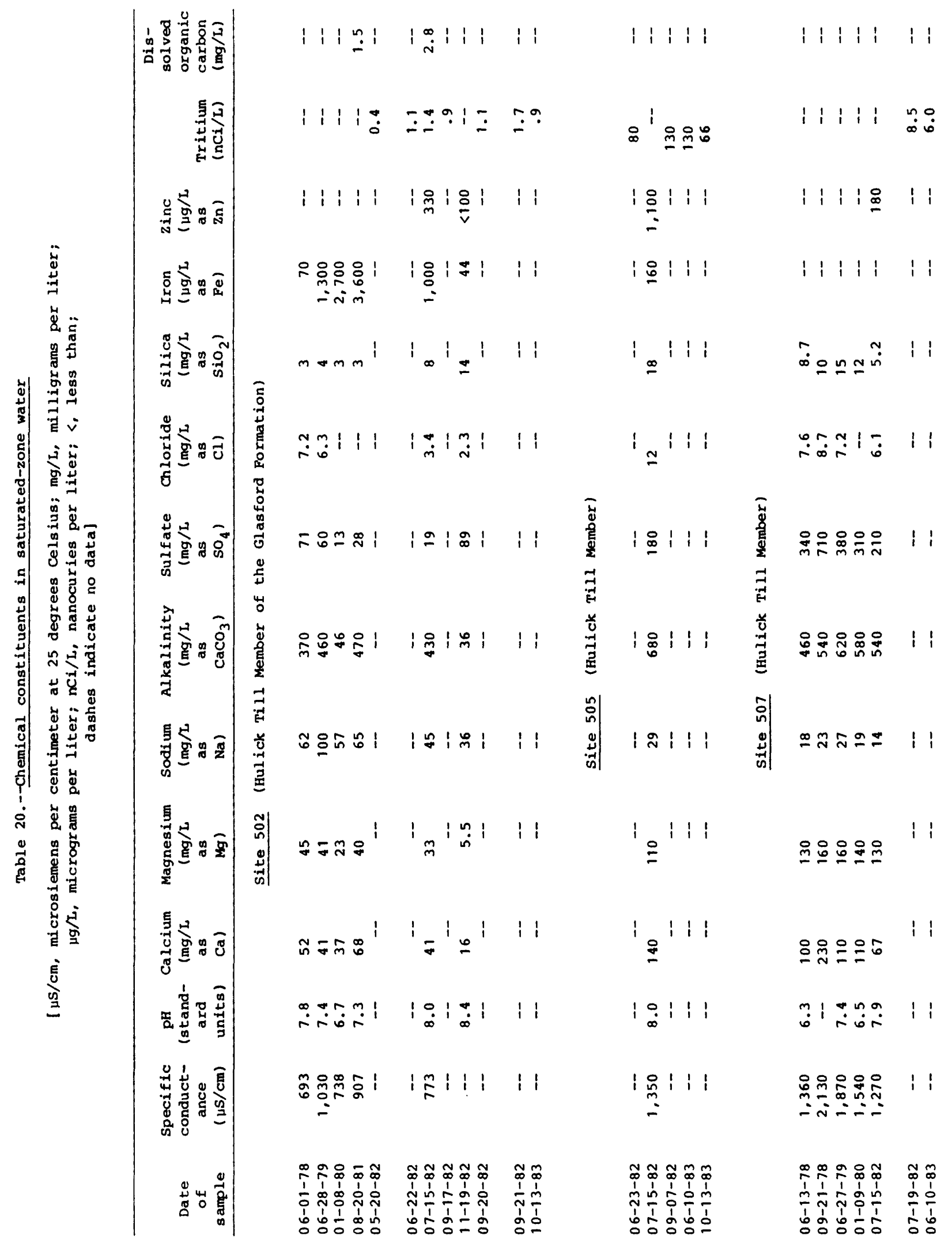




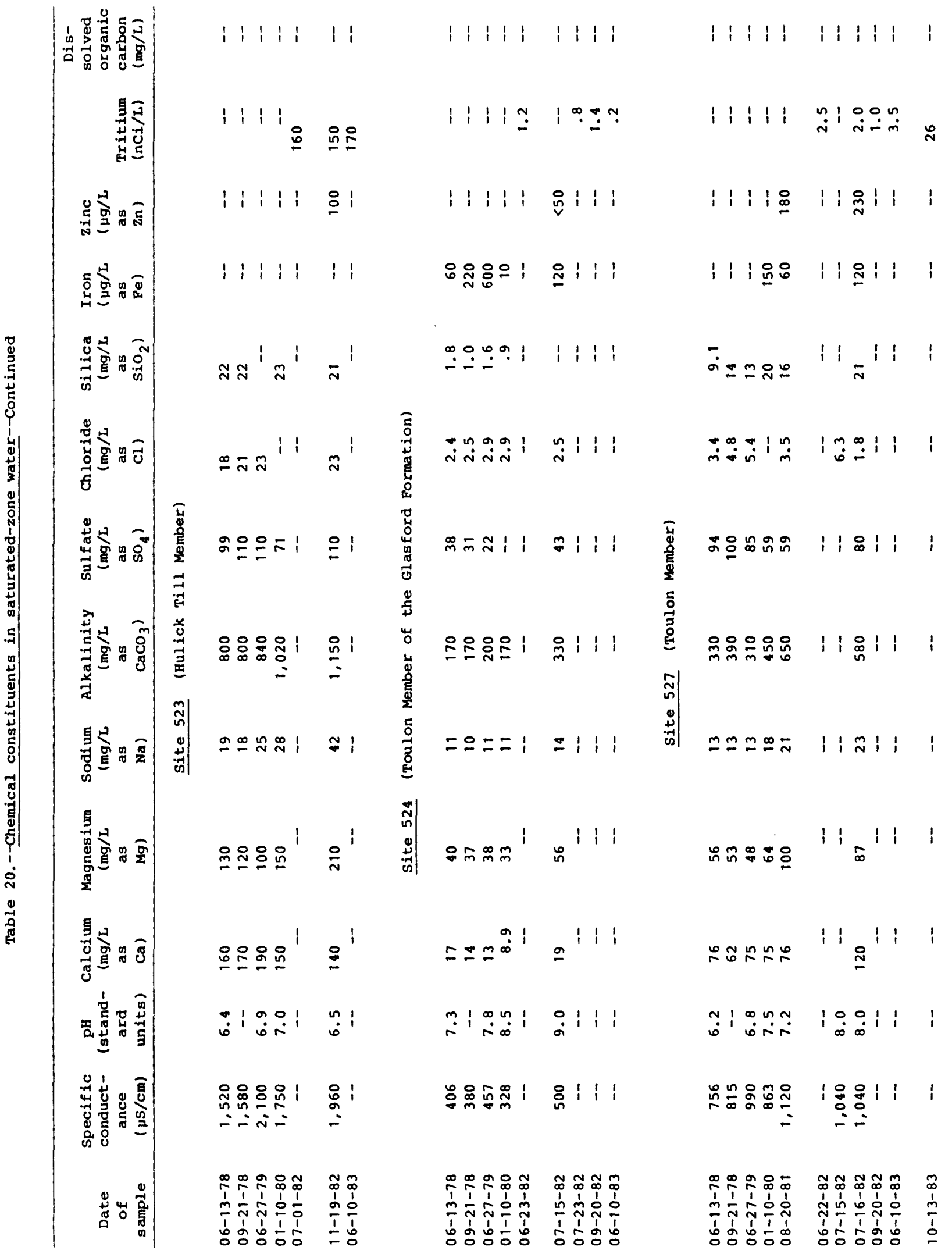




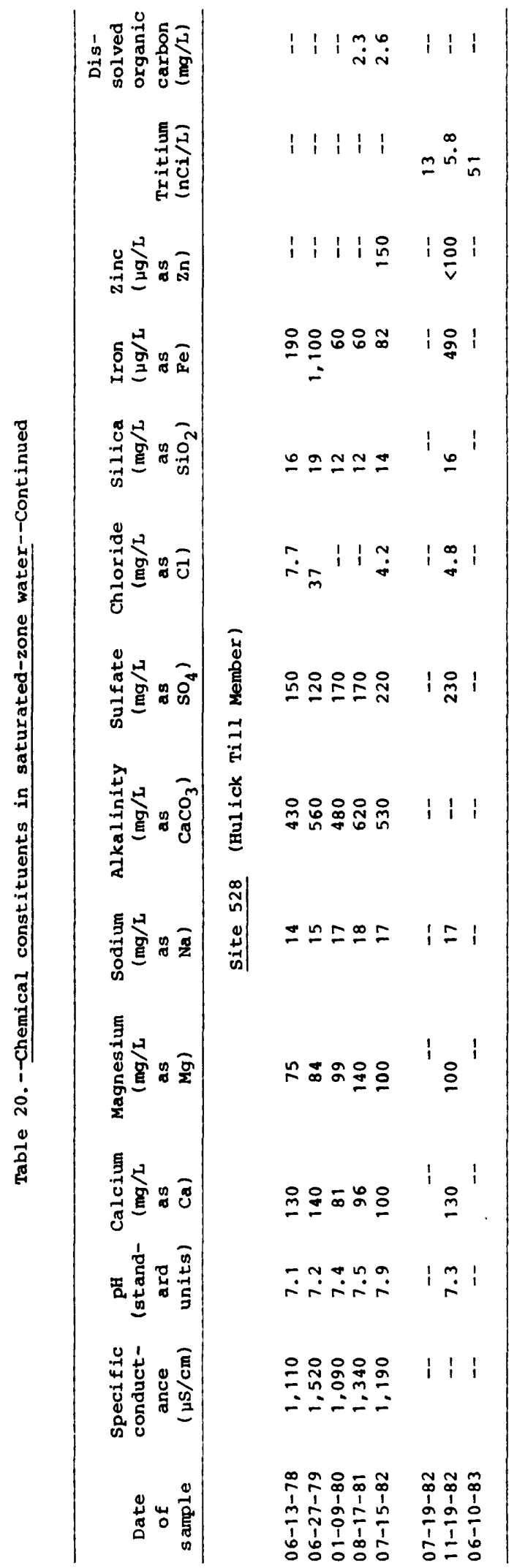

